NATIONAL LABORATORY

\title{
Partial Safety Analysis for a Reduced Uranium Enrichment Core for the High Flux Isotope Reactor
}

\section{April 2009}

C. Galvez Velit

R. T. Primm, III

J. C. Gehin
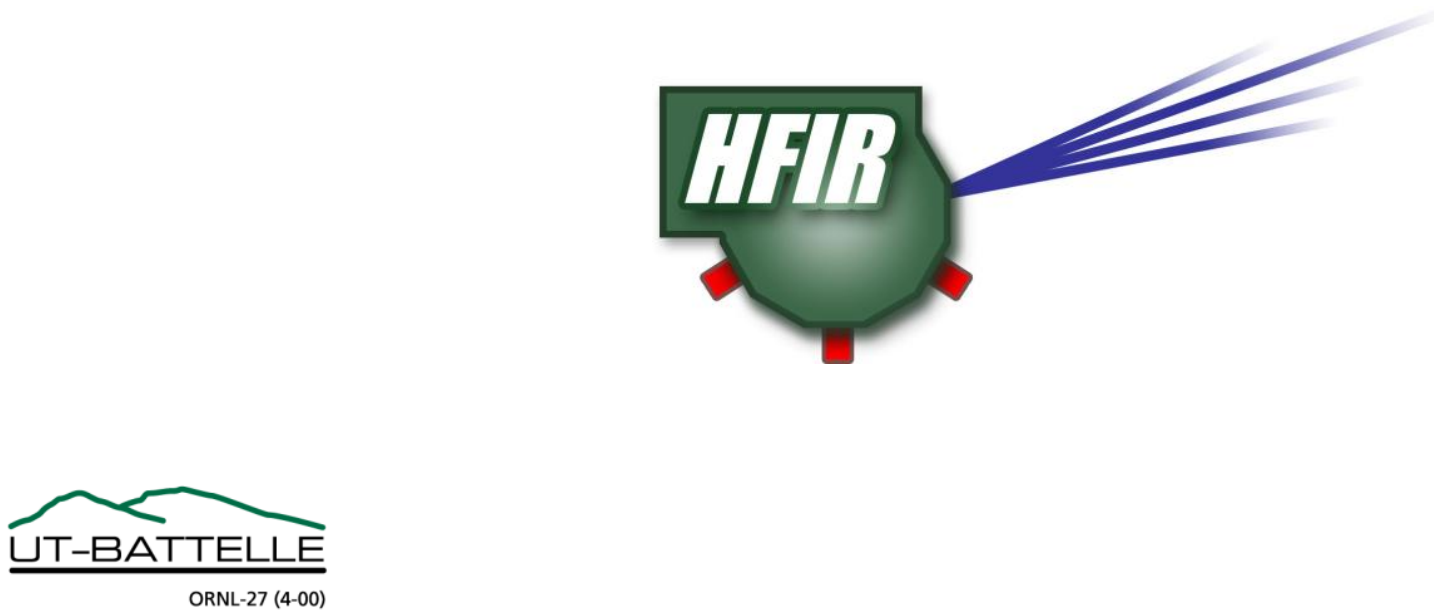


\title{
DOCUMENT AVAILABILITY
}

Reports produced after January 1, 1996, are generally available free via the U.S. Department of Energy (DOE) Information Bridge.

Web site http://www.osti.gov/bridge

Reports produced before January 1, 1996, may be purchased by members of the public from the following source.

\author{
National Technical Information Service \\ 5285 Port Royal Road \\ Springfield, VA 22161 \\ Telephone 703-605-6000 (1-800-553-6847) \\ TDD 703-487-4639 \\ Fax 703-605-6900 \\ E-mail info@ntis.gov \\ Web site http://www.ntis.gov/support/ordernowabout.htm
}

Reports are available to DOE employees, DOE contractors, Energy Technology Data Exchange (ETDE) representatives, and International Nuclear Information System (INIS) representatives from the following source.

Office of Scientific and Technical Information

P.O. Box 62

Oak Ridge, TN 37831

Telephone 865-576-8401

Fax 865-576-5728

E-mail reports@osti.gov

Web site http://www.osti.gov/contact.html

\begin{abstract}
This report was prepared as an account of work sponsored by an agency of the United States Government. Neither the United States Government nor any agency thereof, nor any of their employees, makes any warranty, express or implied, or assumes any legal liability or responsibility for the accuracy, completeness, or usefulness of any information, apparatus, product, or process disclosed, or represents that its use would not infringe privately owned rights. Reference herein to any specific commercial product, process, or service by trade name, trademark, manufacturer, or otherwise, does not necessarily constitute or imply its endorsement, recommendation, or favoring by the United States Government or any agency thereof. The views and opinions of authors expressed herein do not necessarily state or reflect those of the United States Government or any agency thereof.
\end{abstract}


C. Galvez Velit

R. T. Primm, III

J. C. Gehin

April 2009

Prepared by

OAK RIDGE NATIONAL LABORATORY

Oak Ridge, Tennessee 37831-6283

managed by

UT-BATTELLE, LLC

for the

U.S. DEPARTMENT OF ENERGY

under contract DE-AC05-00OR22725 



\section{CONTENTS}

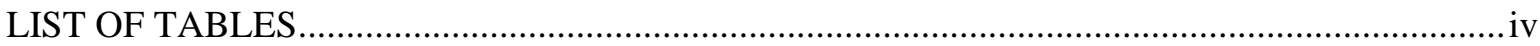

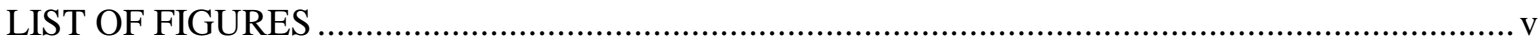

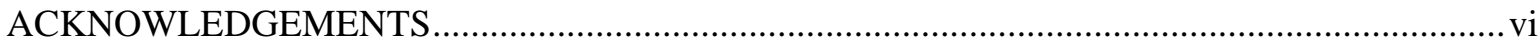

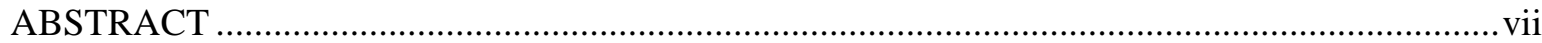

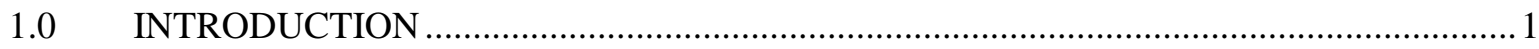

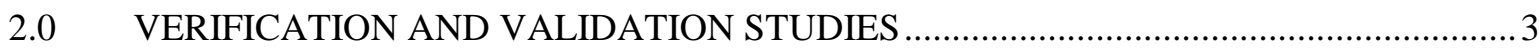

2.1 International Atomic Energy Agency (IAEA) 10 Megawatt Benchmark.................. 3

2.2 The Massachusetts Institute of Technology - II Reactor ........................................5

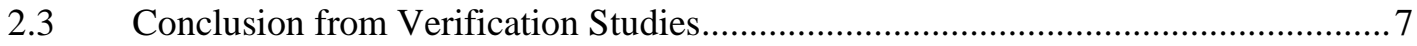

2.4 Validation Studies with Earlier Versions of PARET ........................................ 7

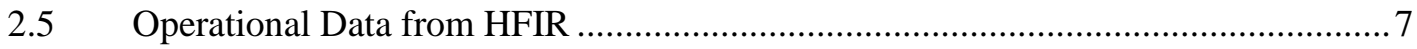

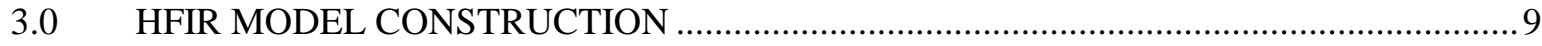

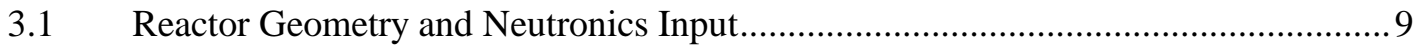

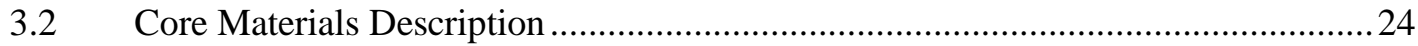

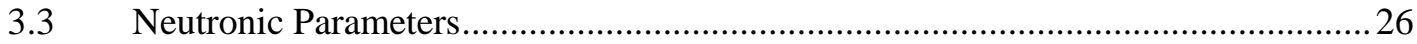

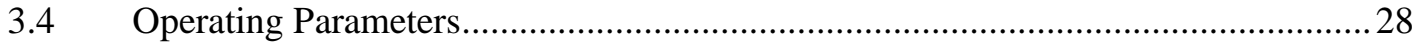

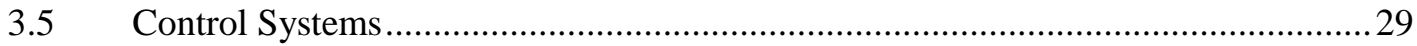

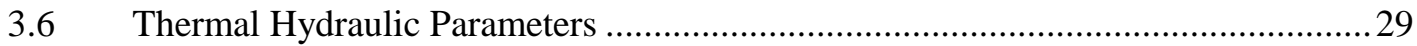

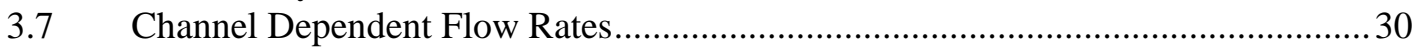

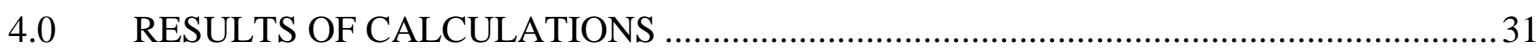

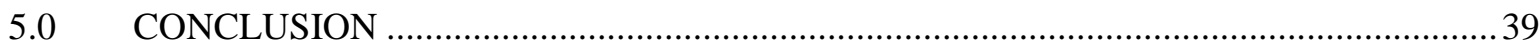

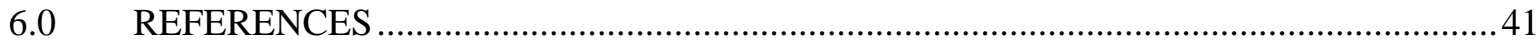

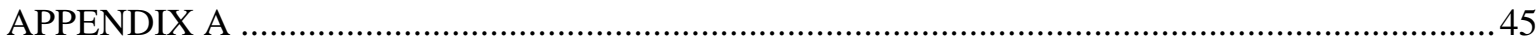




\section{LIST OF TABLES}

2.1 Representative validation studies for PARET with other reactors................................... 7

3.1 Relative pwoer distribution for the inner fuel element, HEU, beginning-of-cycle .............. 12

3.2 Relative power distribution for the inner fuel element, HEU, end-of-cycle ....................... 13

3.3 Relative power distribution for the outer fuel element, HEU, beginning-of-cycle ............... 14

3.4 Relative power distribution for the outer fuel elelment, HEU, end-of-cycle ...................... 15

3.5 Equivalent diameter for each core region in PARET HEU model .................................... 16

3.6 Relative power distribution for the inner fuel element, LEU, beginning-of-cycle................ 17

3.7 Relative power distribution for the outer fuel element, LEU, beginning-of-cycle............... 18

3.8 Relative power distribution for the inner fuel element, LEU, end-of-cycle......................... 19

3.9 Relative power distribution for the otuer fuel element, LEU, end-of-cycle......................... 20

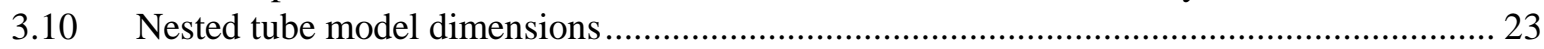

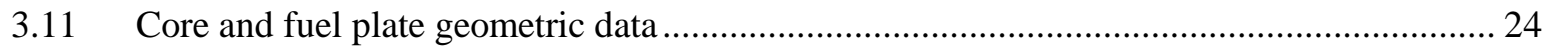

3.12 Fuel and clad material thermal property coefficients................................................... 26

3.13 Reactor kinetics parameters for HEU fuel ............................................................... 27

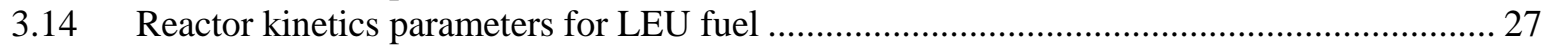

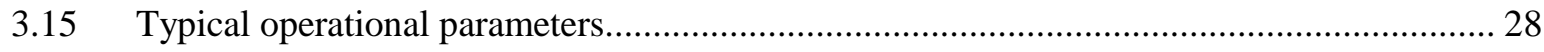

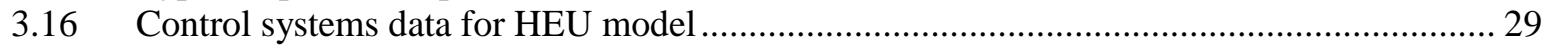

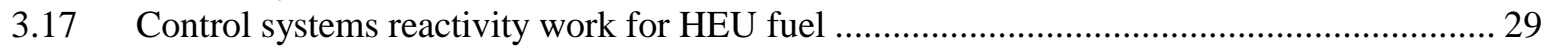

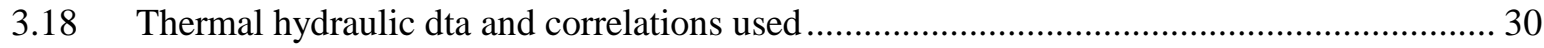

4.1 Primary coolant pump seizure initial and boundary conditions ......................................... 31

A.1 Prompt neutron lifetime and effective delayed neutron fractions for the HFIR HEU core

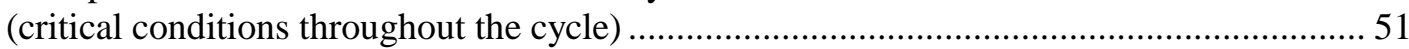

A.2 Prompt neutron lifetime and effective delayed neutron fractions for the HFIR LEU (monolithic U-10Mo) core (critical conditions throughout the cycle) .................................. 51

A.3 Contributions to effective delayed neutron fraction by nuclide for the HEU and LEU cores

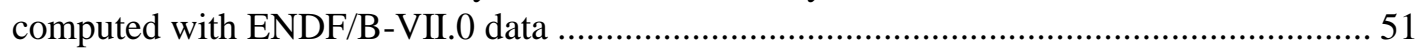




\section{LIST OF FIGURES}

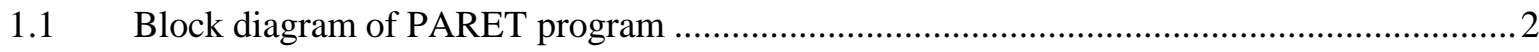

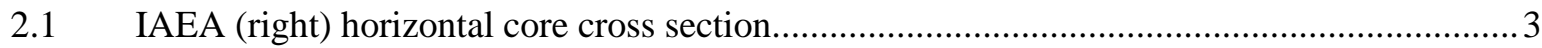

2.2 Transient response of benchmark core to reactivity insertion of $\$ 0.50 / 0.5 \mathrm{~s}$ with an overpower scram trip at $12 \mathrm{MW}$ and a $25 \mathrm{~ms}$ delay from Ref. 4 . .................................... 4

2.3 Transient response of benchmark core to reactivity insertion of $\$ 1.50 / 0.5 \mathrm{~s}$ with an over-power scram trip at $12 \mathrm{MW}$ and a $25 \mathrm{~ms}$ delay (this work) ........................................5

2.4 Comparion of LEU fuel temperature during a reactivity transient as reported by Newton using an old version of PARET (top) and the version 7.2 of PARET

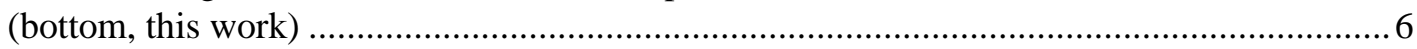

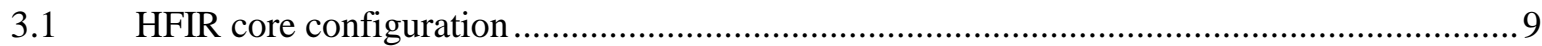

3.2 HFIR involute fuel plates showing variable fuel "meat" thickness within the fuel plate ...... 10

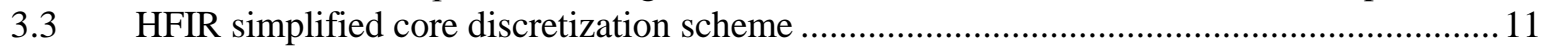

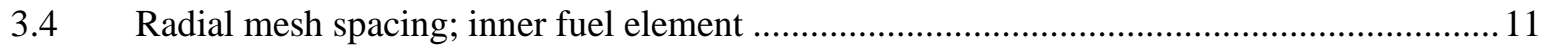

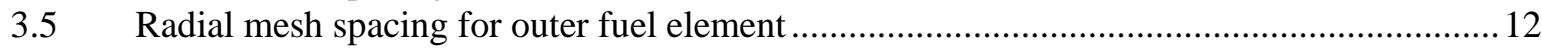

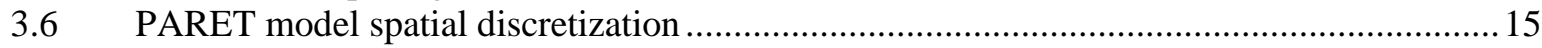

3.7 Plate radial subsectioning used in thermal hydraulic calculation in PARET

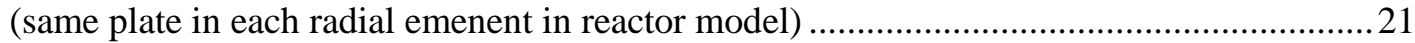

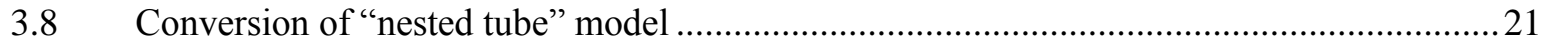

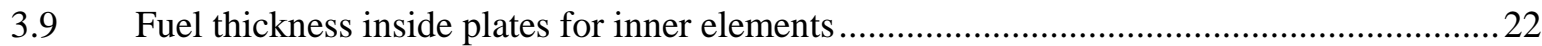

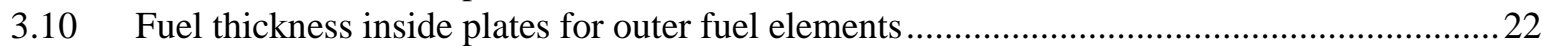

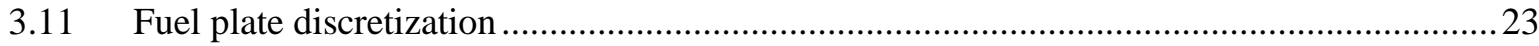

3.12 Thermal conductivity variation as a function of temperature for typical U-A1 fuel

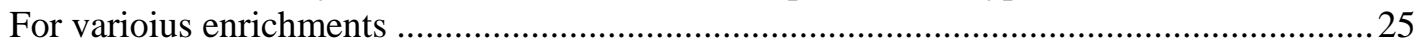

4.1 Mass flux functions for transient in discussion. Note negative values of mass flux As they indicte the downward direction of flow that exists in the HFIR core. 33

4.2 Volumetric flow rate for this transient as found in the most recent version of the USAR of the HFIR. Both initial and final values of he flow are equivalent to the ones shown in the graph, only expressed in different parameters .........................................33

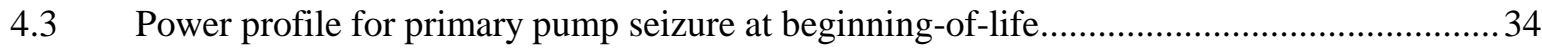

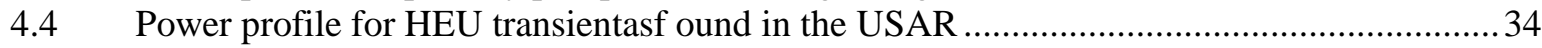

4.5 Reactivity profile of the reduction in primary flow transient as calculated with PARET ..... 35

4.6 Fuel temperature profile for several core regions for HEU for pump seizure transient..........36

4.7 Fuel temperature for transient as reproduced by the USAR ............................................36

4.8 Fuel temperature profile for several core regions for LEU for transient ..............................37

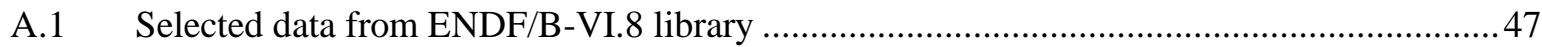

A.2 Selected data from ENDF/B-VII.0 library …...............................................................49

A.3 Comparison of the number of delayed neutrons from ${ }^{235} \mathrm{U}$ fission from ENDF/B-VI.8 and ENDF/B-VII.0 (ENDF/B-VI.8 is identical to ENDF/B-V data).... 


\section{ACKNOWLEDGEMENTS}

The authors would like to acknowledge that the support for this project was provided by the Reduced Enrichment for Research and Test Reactors Program - Argonne National Lab, the Oak Ridge Associated Universities Program and the Oak Ridge Institute for Science and Education. The first author's internship at Oak Ridge National Laboratory was made possible by the Nuclear Engineering Student Laboratory Synthesis (NESLS) program, administered by B. L. Kirk. The authors also acknowledge the useful comments and reviews performed by Arne P. Olson from the Argonne National Lab and K. A. Smith of Oak Ridge National Laboratory. Helpful comments and assistance were provided from J. D Freels, D. H. Cook and all the staff from the Nuclear Safety Group, Research Reactors Division, Oak Ridge National Lab. Finally, the authors wish to thank Mary Wells for her excellence in document preparation and editing. 


\begin{abstract}
A computational model of the reactor core of the High Flux Isotope Rector (HFIR) was developed in order to analyze non-destructive accidents caused by transients during reactor operation. The reactor model was built for the latest version of the nuclear analysis software package called Program for the Analysis of Reactor Transients (PARET). Analyses performed with the model constructed were compared with previous data obtained with other tools in order to benchmark the code. Finally, the model was used to analyze the behavior of the reactor under a transient using a different nuclear fuel with lower enrichment of uranium (LEU) than the fuel currently used, which has a high enrichment of uranium (HEU). The study shows that the presence of fertile isotopes in LEU fuel, which increases the neutron resonance absorption, reduces the impact of transients on the fuel and enhances the negative reactivity feedback, thus, within the limitations of this study, making LEU fuel appear to be a safe alternative fuel for the reactor core.
\end{abstract}





\subsection{INTRODUCTION}

An initiative to investigate the feasibility of low-enriched uranium fuel as a potential alternative fuel for the High Flux Isotope Reactor (HFIR) originated from the Reduced Enrichment for Research and Test Reactors (RERTR). The proof of principle of this project was performed by R T. Primm [1] in a study based on only minor changes to the current fuel design, namely, the thickness of the fuel within the fuel plate.

After this preliminary study was performed, the next logical step was to analyze the safety of this potential fuel for the HFIR. The desired safety analysis would provide information on the behavior of this new fuel design under anticipated transients. At the same time, it was brought to the attention of the author the existence of a nuclear safety computer code called PARET which had not been employed before in this reactor design, and appeared to be an appropriate choice as the main research tool.

There are many potential accident scenarios to be studied, and they are explained in detail on the HFIR Updated Safety Analysis Report [2]. Given that this study is the initial safety analysis being performed, and given the time constrains of the project, the present study was limited to one class of transients. The chosen transient was the primary coolant pump seizure.

PARET [8] is a computer code which iteratively solves for the neutronic-hydrodynamic-heat transfer aspect of the reactor under steady state and transient behavior. This code uses the point reactor kinetics relations for the neutronic aspect of the analysis; furthermore there are multiple laminar and turbulent correlations for the hydrodynamic part and finally an array of heat transfer correlations as well. The user has the capability to select the appropriate correlation based on the operational parameters and the range of data available for the analysis. A simplified diagram showing the functionality of the PARET code is provided in Fig. 1.1, a slightly updated version from that in Ref. 8.

The goals of this study are to:

1. obtain an initial assessment of the safety of the new fuel design, and

2. access PARET as a safety analysis tool for the reactor core in question.

Initially, PARET will be used to benchmark against previously published problems by other researchers that used similar tools in other reactor designs and other transients. After this is accomplished, PARET will be used to re-analyze previously documented transients of the current fuel design, namely highly enriched uranium fuel, and this will allow an initial assessment of the applicability of PARET on the safety analysis of the low enriched uranium fuel. The results of this study will be used as a starting point for a complete safety analysis for the new fuel design. 


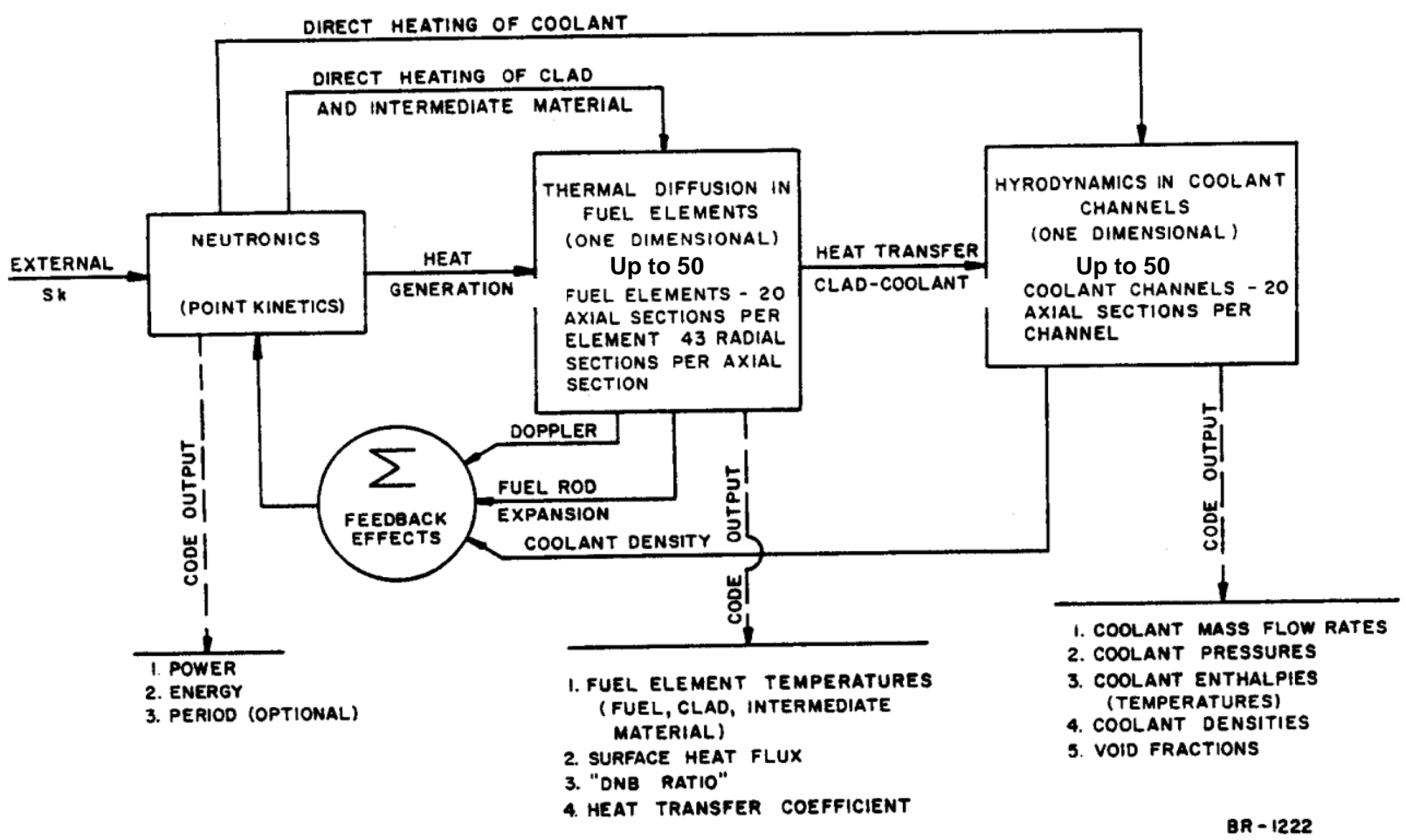

Fig. 1.1. Block diagram of PARET program. 


\subsection{VERIFICATION AND VALIDATION STUDIES}

The version of PARET used in this study is 7.2 and was obtained from A. P. Olson of Argonne National Laboratory [9]. Both WINDOWS and LINUX versions of the code were supplied and both were tested in this project. All calculations reported here were performed with the LINUX version.* Before the code can be used to represent the HFIR reactor core, it is necessary to benchmark it against results published by other researchers obtained with previous versions of the PARET code.

\subsection{International Atomic Energy Agency (IAEA) 10 Megawatt Benchmark}

A 10-MW research reactor core is defined in Ref. 3 in sufficient detail to serve as a benchmark for the PARET code. The IAEA reactor core is shown in Fig. 2.1 and contains four different regions. Three of the core regions are made up of fuel assemblies that are physically similar to each other, but have different fuel enrichments. These three regions are shown shaded in Fig. 2.1. The fourth core region is the fuel-control assembly and there are four of these fuel assemblies in this core. The control elements are the eight white vertical rectangles in Fig. 2.1.

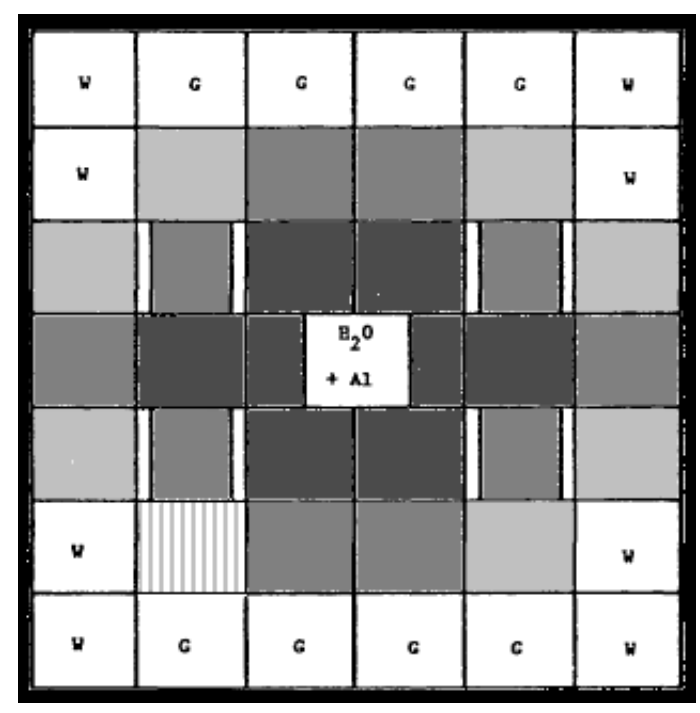

Fig. 2.1. IAEA (right) horizontal core cross section.

The benchmark problem consists of a fast reactivity insertion as described by Woodruff [4]. An input file for the problem was distributed with the PARET code and was used as a didactic tool as well as a base for building the dataset for HFIR. Published results from [4] obtained by using an older version of PARET and also using the RELAP code [5] are shown in Fig. 2.2. Corresponding graphs produced from the output of the current version of PARET are shown in Fig. 2.3. The power profile, peak clad temperature, and peak coolant temperature from the current work all match well to published results in Ref. 4. Peak fuel temperature from the current calculation is slightly lower than that reported in Ref. 4. A change in the materials properties library might be an explanation for the difference.

\footnotetext{
* ORNL Software Registry System ID is 1424.
} 

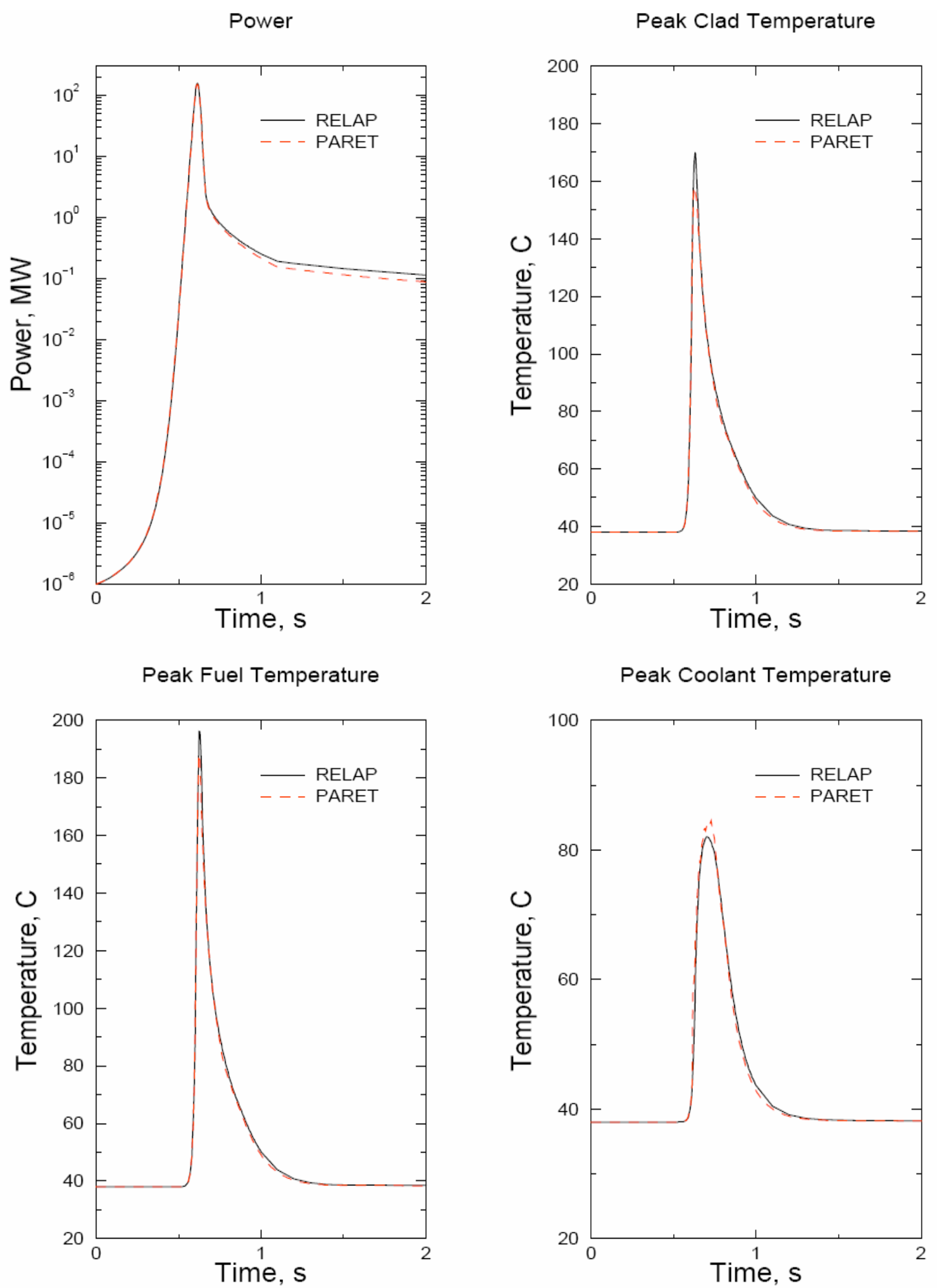

Fig. 2.2. Transient response of benchmark core to reactivity insertion of $\$ 1.50 / 0.5 \mathrm{~s}$ with an overpower scram trip at $12 \mathrm{MW}$ and a $25 \mathrm{~ms}$ delay from [4]. 


\section{Power}

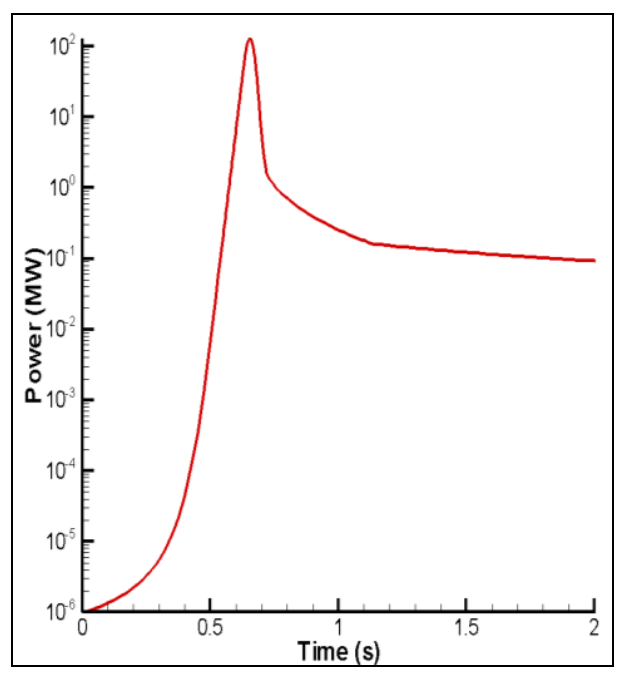

\section{Peak Fuel Temperature}

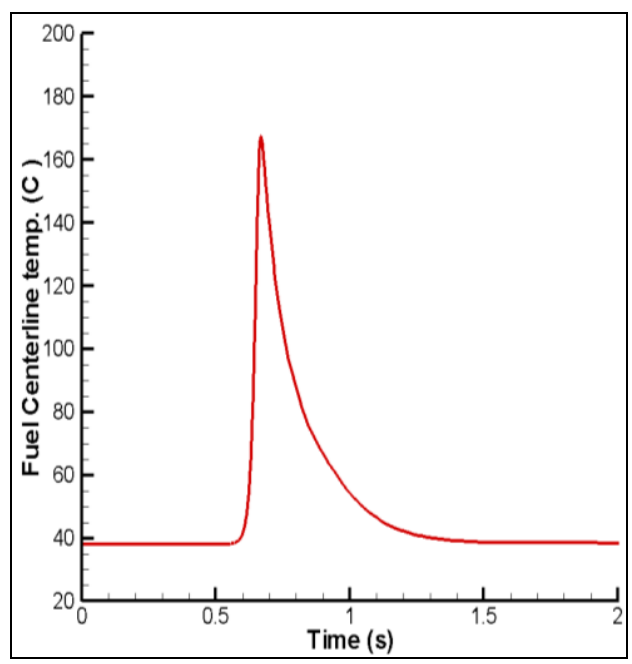

\section{Peak Clad Temperature}

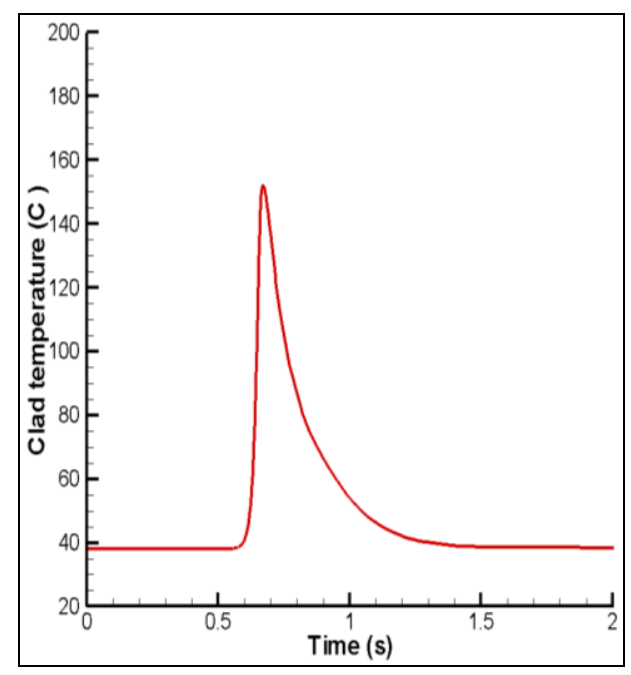

\section{Peak Coolant Temperature}

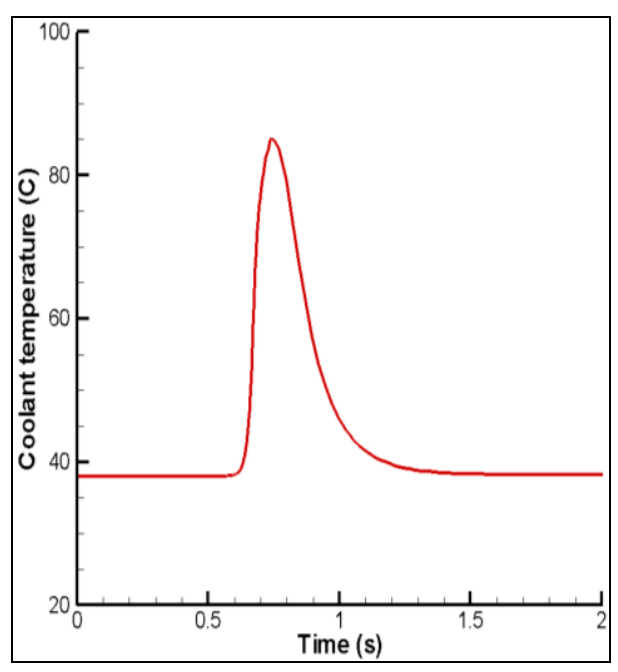

Fig. 2.3. Transient response of benchmark core to reactivity insertion of $\$ 1.50 / 0.5 \mathrm{~s}$ with an over-power scram trip at $12 \mathrm{MW}$ and a 25 ms delay (this work).

\subsection{The Massachusetts Institute of Technology - II Reactor}

The next problem used to benchmark PARET is a reactivity insertion transient at the MIT research reactor (see [6] for reactor description and description of transient). The input file used is provided by Newton [6], who performed a similar study on the mentioned research reactor. As the previous benchmark problem, Newton utilized the older version of PARET. Figure 2.4 shows the level of agreement between the current work and that reported in Ref. 6 . 

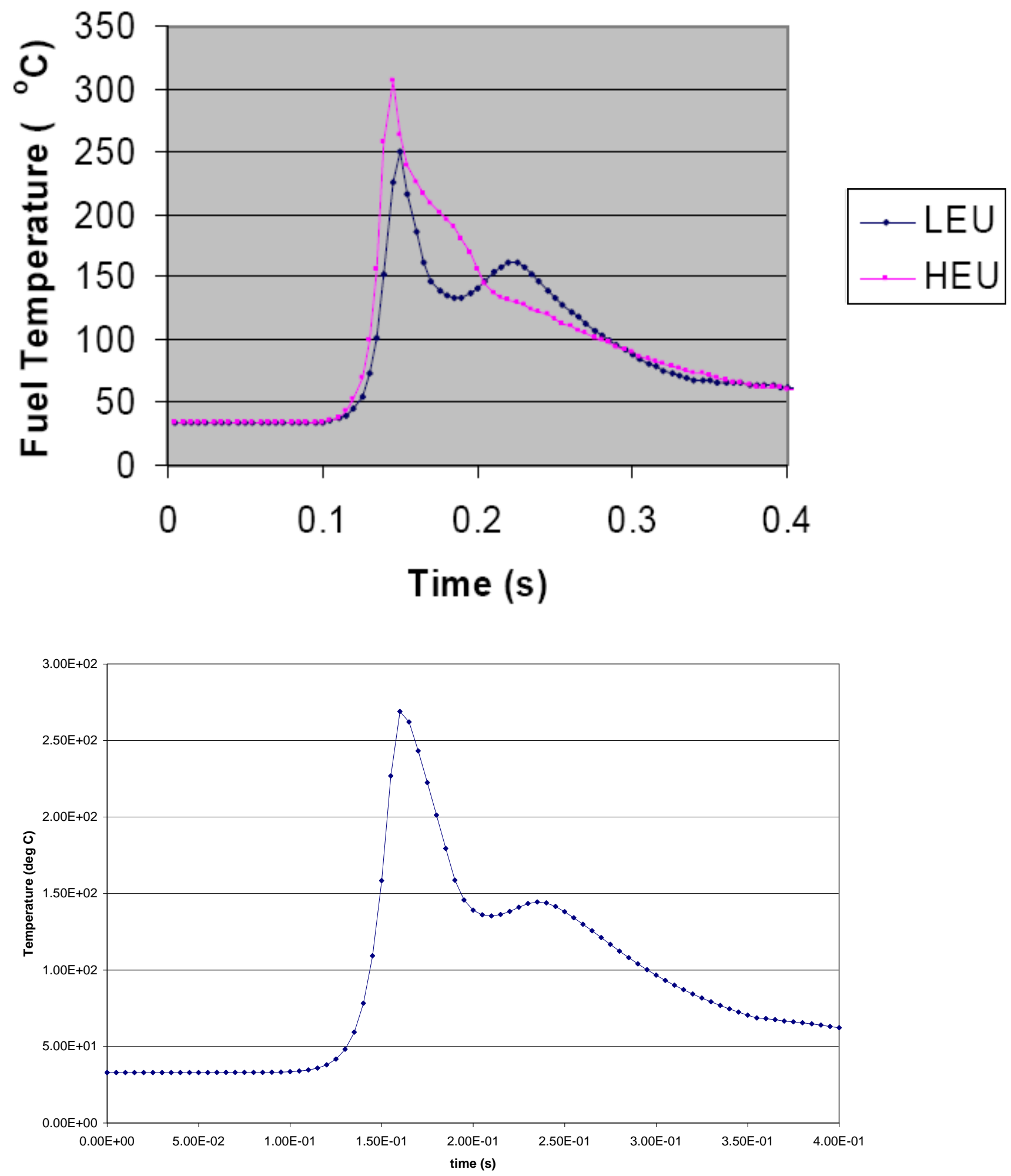

Fig. 2.4. Comparison of LEU fuel temperature during a reactivity transient as reported by Newton using an old version of PARET (top) and the version 7.2 of PARET (bottom, this work). 


\subsection{Conclusion from Verification Studies}

The only input datasets available to the authors were the two discussed in previous sections. It can be inferred from the IAEA and MIT studies that the new version of PARET (7.2) was successfully installed at ORNL and this new version produces results that are consistent with prior versions of PARET. Thus, it is reasonable to apply this code to the HFIR reactor core as it appears capable to handle transients of interest.

\subsection{Validation Studies with Earlier Versions of PARET}

A search of the web-based, Reduced Enrichment for Research and Test Reactors publication database (www.rertr.anl.gov) revealed that calculation-to-experiment comparisons had been made with versions of PARET for three research reactors [11 - 13]. Table 2.1 provides a brief summary of the levels of agreement between calculations and experiments that are reported in these references. In no case was the result of the PARET calculation non-conservative, i.e. less than measurement.

Table 2.1. Representative validation studies for PARET with other reactors

\begin{tabular}{c|c|c|c|c|c}
\hline \multirow{2}{*}{$\begin{array}{c}\text { Ref. } \\
\text { number }\end{array}$} & \multirow{2}{*}{ Reactor } & Peak clad & Peak power & $\begin{array}{c}\text { Core outlet } \\
\text { coolant } \\
\text { temperature }\end{array}$ & $\begin{array}{c}\text { Margin to incipient } \\
\text { boiling }\end{array}$ \\
\cline { 3 - 6 } & SPERT-IV & $\begin{array}{c}\text { Always }>1.0, \\
\text { max of } 1.73 \text { for } \\
\$ 1.8 \text { transient }\end{array}$ & $1.0-1.1$ & - & - \\
\hline $12 \mathrm{a}$ & MNSR & - & - & $\sim 1.0$ & $\begin{array}{c}\text { Agrees with } \\
\text { prediction from } \\
\text { correlation derived } \\
\text { from expts for } 3.77 \\
\text { mk transient }\end{array}$ \\
\hline $13 \mathrm{a}$ & ORR & - & $1-2.75$ & - & - \\
\hline
\end{tabular}

Computer programs can be validated by comparison to other, similar computer programs for which the level of accuracy is known over a specified area of applicability (see Fig. 2.2). Several computational comparisons among PARET and other codes have been documented [14 - 17] but are not reviewed here.

\subsection{Operational Data from HFIR}

Records in the operators' log books for the HFIR exist that can be used to validate the PARET program and associated materials property library. These include:

1) shutdown from full power - coolant outlet temperature as a function of time,

2) as rods are pulled at startup and power increases at some rate, outlet coolant temperature as a function of time, and

3) power change as a function of time due to reactivity insertion caused by "rabbits" (capsules) inserted in the hydraulic tube located in the central target region of HFIR [18]. 
The object of the studies documented in this report was to create the PARET models for HEU-fuelled and LEU-fuelled HFIR cores. A follow-on study could use the models to conduct validation studies with these HFIR operational data. 


\subsection{HFIR MODEL CONSTRUCTION}

It is necessary to define the following terms as they will be used throughout this document. For any type of reactor - power or research or other - the reactor core is a three dimensional body that typically can be represented in terms of two dimensional core regions perpendicular to the unidirectional flow of coolant (i.e., axial slices through the three dimensional body). Each "slice" or core region is frequently composed of multiple fuel assemblies and each fuel assembly consists of multiple fuel plates and coolant channels.

\subsection{Reactor Geometry and Neutronics Input}

The core design of the HFIR is shown in Fig. 3.1 and differs from the typical plate-fueled reactor core. As it can be observed, the HFIR reactor core is made up of two regions, the inner and outer annulus which contains the curved fuel plates. These two regions are different since the fuel plates that make up each region contain different uranium loadings and differing curvatures. The control elements are the two sparsely shaded outer annuli in the HFIR core.

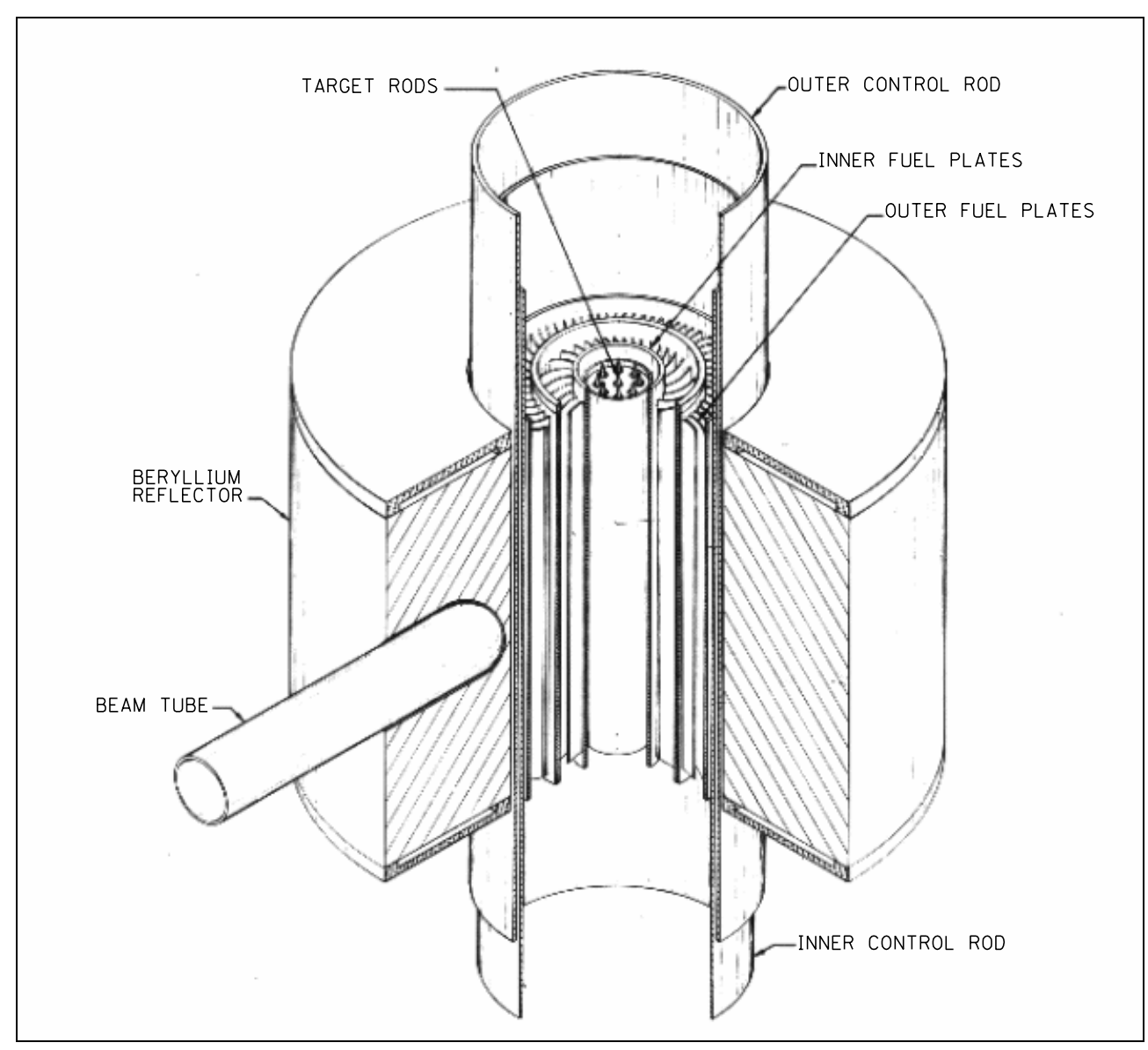

Fig. 3.1. HFIR core configuration. 
The HFIR fuel plates are curved, with an involute shape, whereas the fuel plates of the IAEA core (Fig. 2.1) are flat plates. There are 23 fuel plates per fuel assembly and 17 fuel plates per fuel-control assembly in the IAEA core. In the HFIR core there are 171 fuel plates in the inner fuel region and 369 fuel plates in the outer fuel region (refer to Fig. 3.1). In addition to this difference, the layer of fuel in the HFIR does not have constant thickness along the width of the fuel plate, however the standard fuel plate, such as that of the IAEA core has a constant fuel layer thickness along the width of the fuel plate [7]. Fuel plates for the inner fuel element have a different arc of curvature from those of the outer fuel element (see Fig. 3.2).
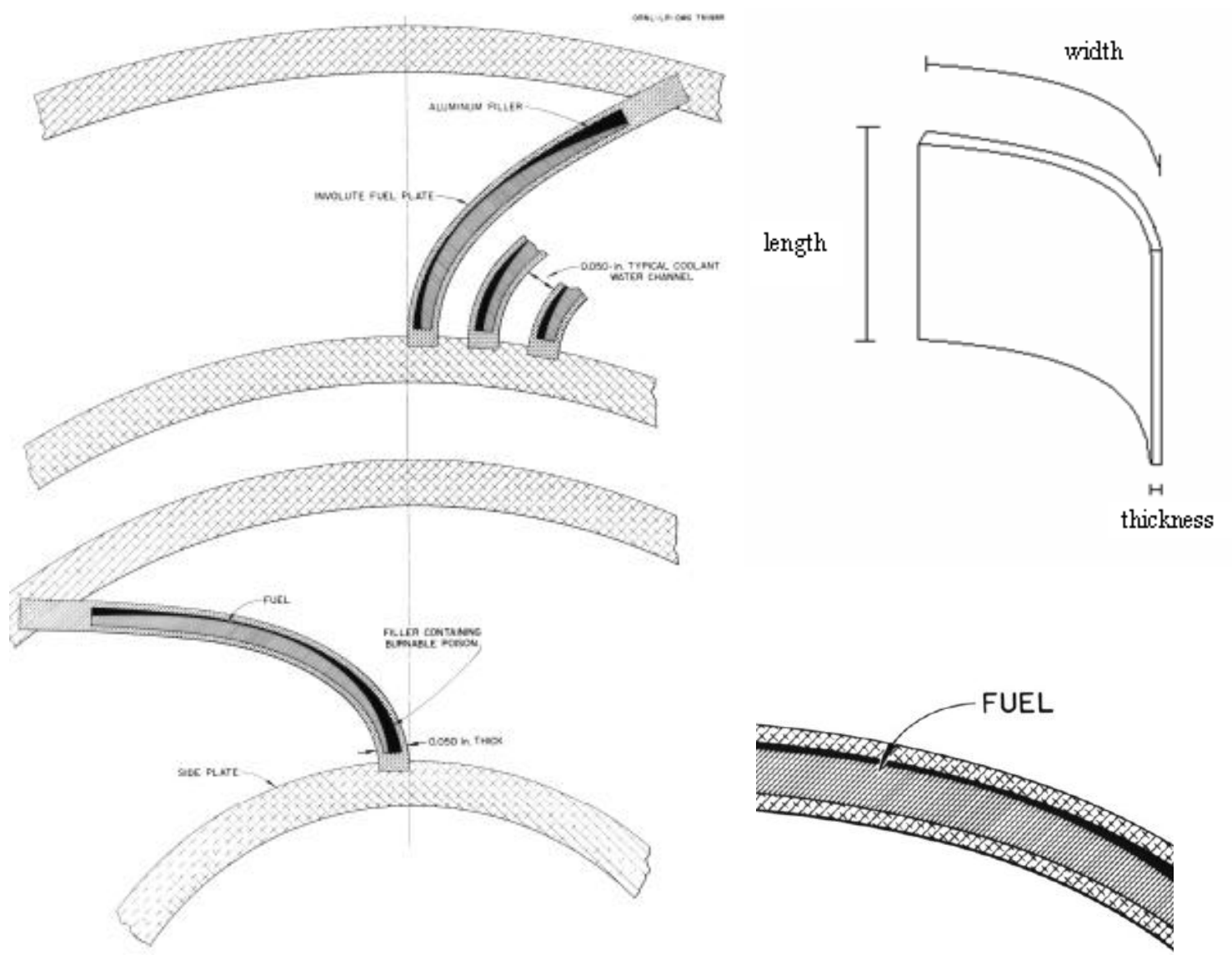

Fig. 3.2. HFIR involute fuel plates showing variable fuel 'meat' thickness within the fuel plate.

In order to model the HFIR core in PARET, is necessary to decide the number of core regions that are to be modeled. Given that the power distribution in not uniform across both fuel elements of the reactor, it is necessary to spatially discretize the reactor core so as to model these non-uniformities. The discretization must be such that there are enough nodes as to accurately describe the power distribution, yet should not be so large as to lead to long computational time due to an unnecessary large number of mesh points. Thus, a discretization must be done to the inner and outer fuel elements and along the height of the core such that the ratio of the local power to the average power can be represented in both directions, radial and axial. 
Based on the a recent static reactor physics study by Primm [10], the power distribution of each of the two fuel elements of the core can be accurately represented by eight radial regions in the inner fuel and nine radial regions in the outer fuel. Nineteen axial zones were present in the neutronics model - one less than the maximum allowed in PARET. Fig. 3.3 shows this relation for the HEU fuel. Figs. 3.4 and 3.5 show the radial discretization schemes for the inner and outer elements. Axial mesh intervals had a uniform thickness of $3 \mathrm{~cm}$ except for the top and bottom interval which were each $0.4 \mathrm{~cm}$ and the interval containing the axial midplane which was $2 \mathrm{~cm}$. The power distribution for beginning-oflife in the inner element is presented in Table 3.1

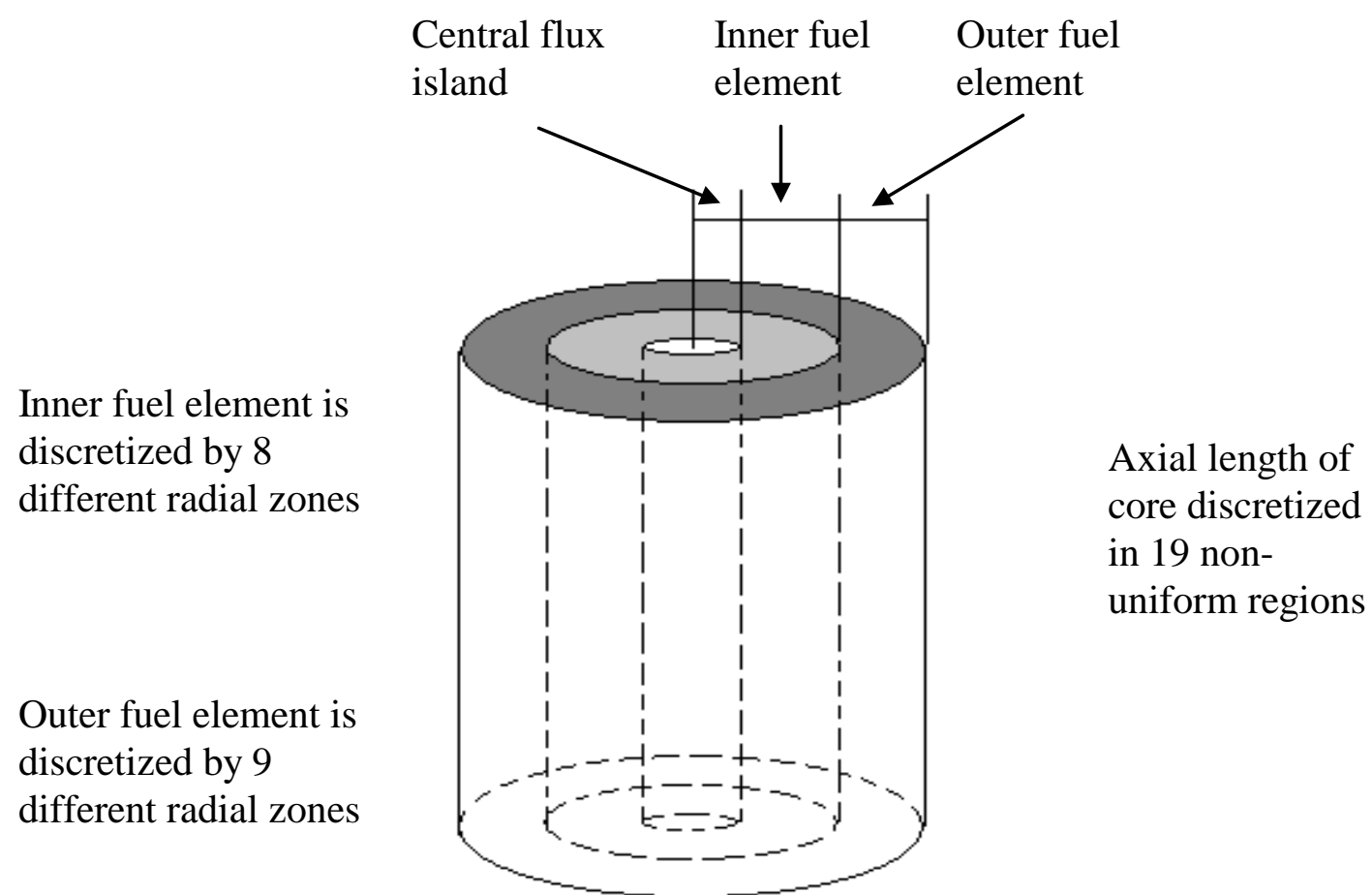

Fig. 3.3. HFIR simplified core discretization scheme.

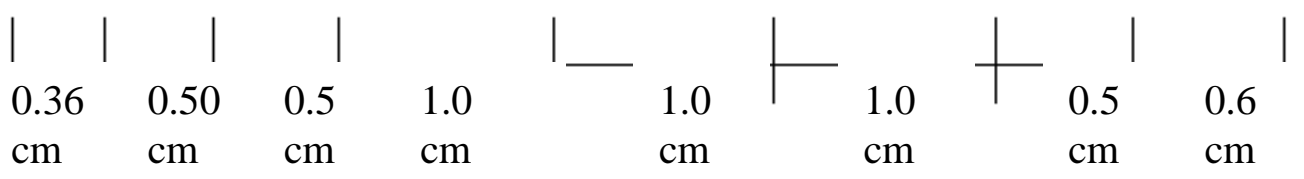

$7.141 \mathrm{~cm}$

Inner radius

$12.598 \mathrm{~cm}$

Outer radius

Fig. 3.4. Radial mesh spacing; inner fuel element. 


$\begin{array}{lllllllll}0.36 & 0.50 & 0.5 & 1.0 & 1.0 & 1.0 & 0.5 & 0.5 & 0.48 \\ \mathrm{~cm} & \mathrm{~cm} & \mathrm{~cm} & \mathrm{~cm} & \mathrm{~cm} & \mathrm{~cm} & \mathrm{~cm} & \mathrm{~cm} & \mathrm{~cm}\end{array}$

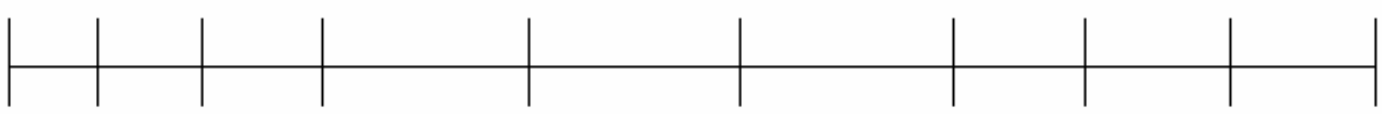

$15.13 \mathrm{~cm}$

$20.93 \mathrm{~cm}$

Inner radius

Outer radius

Fig. 3.5. Radial mesh spacing for outer fuel element.

Table 3.1. Relative power distribution for the inner fuel element, HEU, beginning-of-cycle Power Level Distribution Inner Fuel Element: HEU Fuel

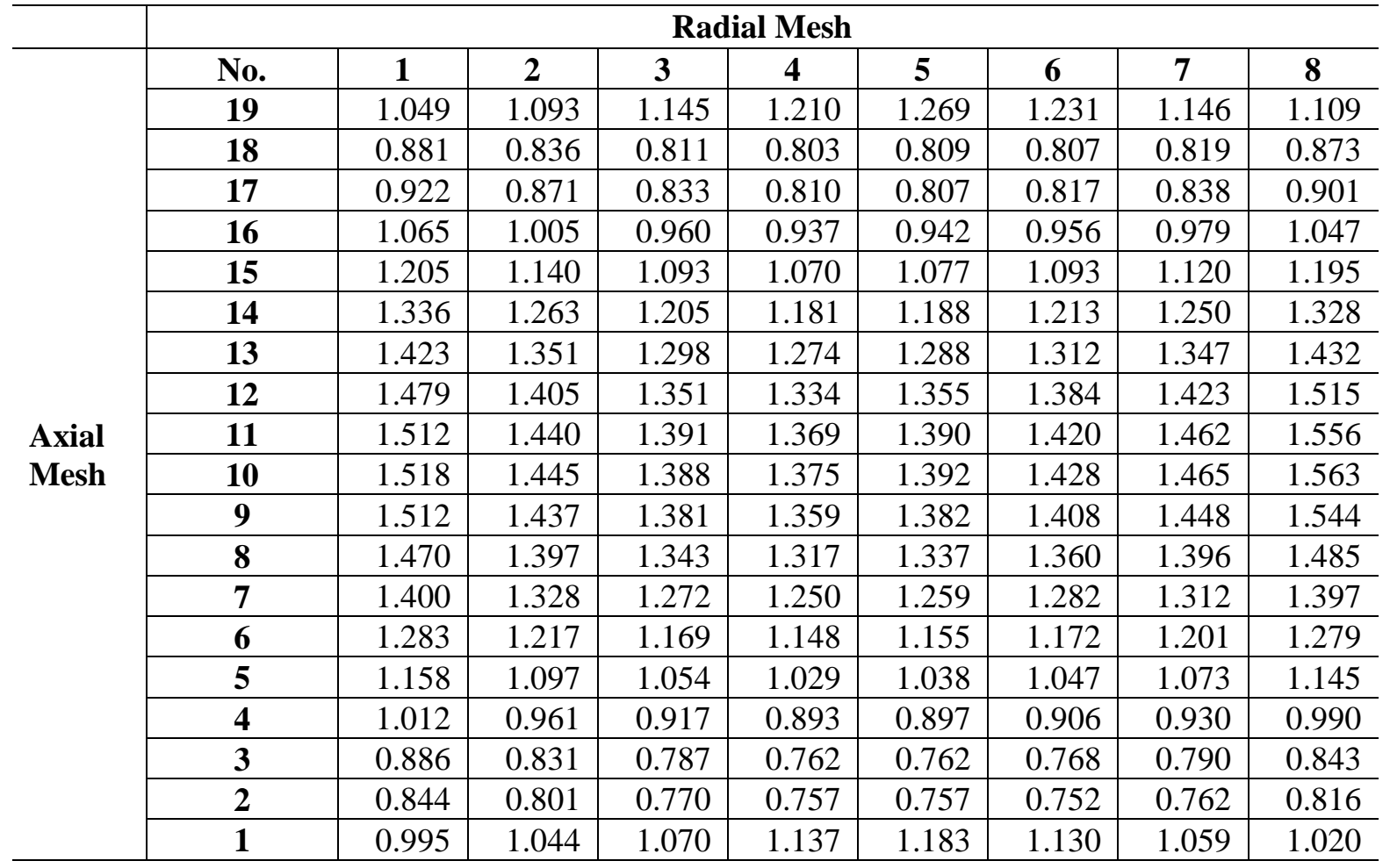


Data in Table 3.1 as well as in Tables 3.2 through 3.4 were calculated with the MCNP-V code using a HFIR model documented in Ref. 31. End-of-life power profiles were determined by incorporating the HFIR MCNP model into the ALEPH [32] Monte Carlo depletion code system.

Table 3.2. Relative power distribution for the inner fuel element, HEU, end-of-cycle Power Level Distribution Inner Fuel Element: HEU Fuel

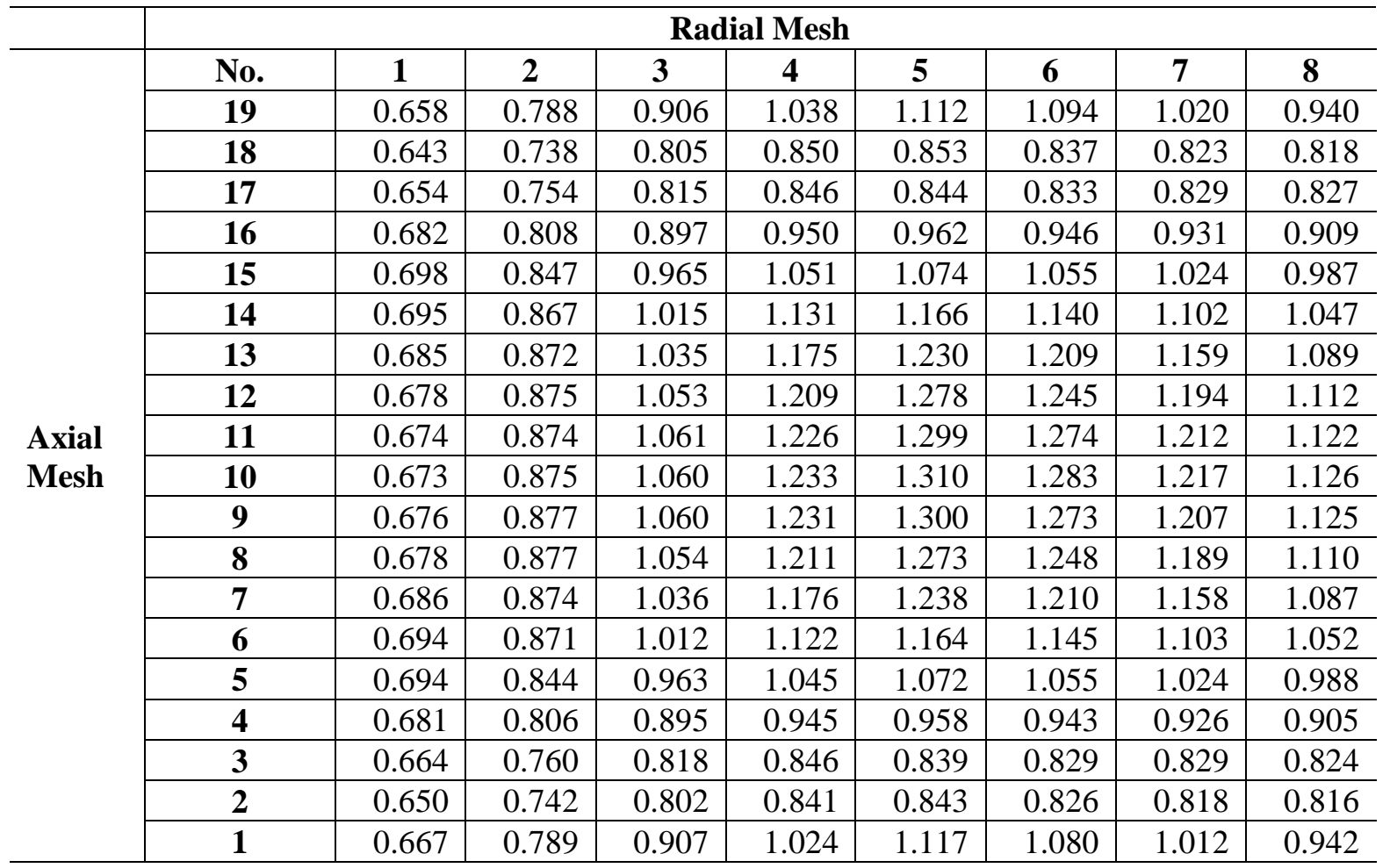

The computer code allows the user to define multiple core regions with its own specified power generation levels as well as its own reactivity feedback intensity factors for the moderator and the fuel, as described by Obenchain [8]. Each of these core regions are independent from each other in terms of the hydrodynamic and heat transfer aspect, but coupled to all other regions defined in terms of the reactor kinetics and reactivity feedback effects. This is very important, given that PARET does not consider the spatial effects of the core in general for the computation. In fact, in PARET, the geometric configuration of the core, cylindrical or rectangular, is only used in the determination of the total heat transfer area and, consequently, the total heat flux. However, it is important to specify the appropriate equivalent diameter for the core region being defined (the "element") since this will determine the coolant flow velocity in that particular region. 
Table 3.3. Relative power distribution for the outer fuel element, HEU, beginning-of-cycle Power Level Distribution Outer Fuel Element: HEU Fuel

\begin{tabular}{|c|c|c|c|c|c|c|c|c|c|c|}
\hline & \multicolumn{10}{|c|}{ Radial Mesh } \\
\hline \multirow{20}{*}{$\begin{array}{l}\text { Axial } \\
\text { Mesh }\end{array}$} & No. & 9 & 10 & 11 & 12 & 13 & 14 & 15 & 16 & 17 \\
\hline & 19 & 1.141 & 1.177 & 1.195 & 1.173 & 1.020 & 0.781 & 0.586 & 0.467 & 0.354 \\
\hline & 18 & 0.908 & 0.847 & 0.800 & 0.733 & 0.624 & 0.509 & 0.416 & 0.352 & 0.291 \\
\hline & 17 & 0.935 & 0.875 & 0.826 & 0.755 & 0.642 & 0.529 & 0.438 & 0.375 & 0.314 \\
\hline & 16 & 1.087 & 1.029 & 0.978 & 0.901 & 0.778 & 0.655 & 0.553 & 0.478 & 0.409 \\
\hline & 15 & 1.244 & 1.177 & 1.124 & 1.048 & 0.923 & 0.805 & 0.712 & 0.654 & 0.592 \\
\hline & 14 & 1.383 & 1.319 & 1.263 & 1.179 & 1.053 & 0.943 & 0.859 & 0.807 & 0.756 \\
\hline & 13 & 1.504 & 1.429 & 1.369 & 1.286 & 1.161 & 1.047 & 0.966 & 0.917 & 0.866 \\
\hline & 12 & 1.590 & 1.508 & 1.444 & 1.364 & 1.235 & 1.128 & 1.055 & 1.011 & 0.964 \\
\hline & 11 & 1.637 & 1.561 & 1.499 & 1.414 & 1.289 & 1.202 & 1.144 & 1.112 & 1.079 \\
\hline & 10 & 1.645 & 1.561 & 1.501 & 1.418 & 1.300 & 1.220 & 1.174 & 1.156 & 1.127 \\
\hline & 9 & 1.620 & 1.542 & 1.480 & 1.395 & 1.272 & 1.177 & 1.116 & 1.082 & 1.045 \\
\hline & 8 & 1.555 & 1.479 & 1.425 & 1.335 & 1.205 & 1.092 & 1.008 & 0.954 & 0.893 \\
\hline & 7 & 1.455 & 1.386 & 1.332 & 1.248 & 1.111 & 0.996 & 0.913 & 0.857 & 0.798 \\
\hline & 6 & 1.332 & 1.267 & 1.211 & 1.129 & 1.002 & 0.890 & 0.809 & 0.754 & 0.698 \\
\hline & 5 & 1.187 & 1.122 & 1.069 & 0.996 & 0.866 & 0.742 & 0.646 & 0.585 & 0.520 \\
\hline & 4 & 1.029 & 0.970 & 0.922 & 0.841 & 0.713 & 0.573 & 0.456 & 0.376 & 0.297 \\
\hline & 3 & 0.879 & 0.819 & 0.768 & 0.693 & 0.577 & 0.457 & 0.357 & 0.289 & 0.221 \\
\hline & 2 & 0.847 & 0.787 & 0.739 & 0.665 & 0.554 & 0.430 & 0.332 & 0.265 & 0.200 \\
\hline & 1 & 1.063 & 1.079 & 1.098 & 1.060 & 0.887 & 0.655 & 0.472 & 0.353 & 0.244 \\
\hline
\end{tabular}

Fig. 3.6 shows a "cylindrical" representation of HFIR that is to be converted into a "nested tube in slab geometry" option for the PARET computational model. The core is divided into 17 radial regions, each having its own power generation, coolant flow rate, hydraulic parameters, etc. and each represented by a single fuel plate plus its associated coolant channel. Each of the radial regions is further subdivided into 19 axial sections (one less than the maximum available in the PARET code). Each of these 17 radial regions is termed an "element" in the vocabulary of the PARET documentation $[8,9]$. Materials Test Reactor-type of research reactors do, indeed, have cores composed of physically separate fuel elements. For HFIR, the designation is artificial and necessary in order to model the graded fuel thickness inside each fuel plate (see Fig. 3.2).

Table 3.5 shows the radial mesh spacing for the PARET model corresponding to Fig. 3.6. The mesh spacing differs from that shown in Fig. 3.4 and 3.5 because the central target region of the reactor is not modeled and, since PARET does not consider three dimensional spatial effects for the thermal conduction or neutronic aspects of the calculation, there is no need for separate models of the inner and outer element fuel plates. However, consistency in defining the two dimensional distribution of the core regions (horizontal core cross section) is important since the heat removal capacity will be calculated from this parameters. Note that the radial mesh spacing in Table 3.5 is the radial mesh for the "elements" (PARET terminology). There are no nodes between identified mesh points. The fuel plate model for each "element", i.e. the mesh inside a fuel plate channel - limited to 43 mesh points is described subsequently. 
Table 3.4. Relative power distribution for the outer fuel element, HEU, end-of-cycle Power Level Distribution Outer Fuel Element: HEU Fuel

\begin{tabular}{|c|c|c|c|c|c|c|c|c|c|c|}
\hline & \multicolumn{10}{|c|}{ Radial Mesh } \\
\hline \multirow{20}{*}{$\begin{array}{l}\text { Axial } \\
\text { Mesh }\end{array}$} & No. & 9 & 10 & 11 & 12 & 13 & 14 & 15 & 16 & 17 \\
\hline & 19 & 1.001 & 1.090 & 1.171 & 1.235 & 1.168 & 1.028 & 0.892 & 0.802 & 0.713 \\
\hline & 18 & 0.843 & 0.848 & 0.839 & 0.810 & 0.761 & 0.727 & 0.707 & 0.696 & 0.677 \\
\hline & 17 & 0.843 & 0.849 & 0.843 & 0.811 & 0.764 & 0.754 & 0.752 & 0.751 & 0.738 \\
\hline & 16 & 0.928 & 0.955 & 0.958 & 0.929 & 0.884 & 0.868 & 0.859 & 0.843 & 0.806 \\
\hline & 15 & 1.007 & 1.047 & 1.059 & 1.044 & 0.998 & 0.975 & 0.950 & 0.916 & 0.853 \\
\hline & 14 & 1.070 & 1.130 & 1.153 & 1.136 & 1.084 & 1.053 & 1.012 & 0.956 & 0.864 \\
\hline & 13 & 1.114 & 1.184 & 1.219 & 1.209 & 1.151 & 1.112 & 1.054 & 0.977 & 0.856 \\
\hline & 12 & 1.136 & 1.226 & 1.271 & 1.258 & 1.199 & 1.154 & 1.082 & 0.989 & 0.850 \\
\hline & 11 & 1.155 & 1.243 & 1.290 & 1.285 & 1.227 & 1.179 & 1.097 & 0.993 & 0.844 \\
\hline & 10 & 1.155 & 1.257 & 1.299 & 1.302 & 1.234 & 1.185 & 1.096 & 0.993 & 0.844 \\
\hline & 9 & 1.153 & 1.244 & 1.296 & 1.289 & 1.226 & 1.176 & 1.094 & 0.992 & 0.844 \\
\hline & 8 & 1.139 & 1.226 & 1.269 & 1.258 & 1.199 & 1.152 & 1.080 & 0.987 & 0.847 \\
\hline & 7 & 1.114 & 1.186 & 1.220 & 1.211 & 1.154 & 1.115 & 1.057 & 0.976 & 0.856 \\
\hline & 6 & 1.070 & 1.132 & 1.154 & 1.138 & 1.084 & 1.052 & 1.017 & 0.962 & 0.867 \\
\hline & 5 & 1.009 & 1.051 & 1.063 & 1.045 & 0.991 & 0.971 & 0.953 & 0.917 & 0.854 \\
\hline & 4 & 0.928 & 0.957 & 0.958 & 0.932 & 0.884 & 0.873 & 0.865 & 0.851 & 0.812 \\
\hline & 3 & 0.839 & 0.844 & 0.836 & 0.807 & 0.763 & 0.753 & 0.755 & 0.755 & 0.740 \\
\hline & 2 & 0.841 & 0.844 & 0.836 & 0.808 & 0.754 & 0.720 & 0.697 & 0.683 & 0.663 \\
\hline & 1 & 1.000 & 1.097 & 1.165 & 1.220 & 1.151 & 1.001 & 0.869 & 0.770 & 0.672 \\
\hline
\end{tabular}

17 total radial rings of $\quad \mathrm{i}=1 \ldots 17$ unequal thicknesses

$$
\mathrm{j}=1 \ldots 19
$$

7 axial disks of unequal length
Center cylinder plus 7 next rings represent the inner fuel element. Next 9 rings represent the outer fuel element. Ascending order from inner to outer for mesh nomenclature

Bottom axial disk is number 1 and increases in ascending order until disk number 19 at the top.

Fig. 3.6. PARET model spatial discretization. 
The justification for not modeling the central target region or between-element gap is that, since thermal conduction is not incorporated in PARET, the amount of cooling provided by these two channels is neglected. Similarly, since PARET employs point kinetics, reactivity feedback given by these two channels cannot be modeled. It is noteworthy that an optimal void within the flux trap is the maximum reactivity worth accident that can be speculated to occur. Such scenario is not considered in the present study.

The area of flow of each horizontal cross section core region of the PARET model is equal to that of its corresponding core region of the HFIR reactor core. This is a necessary constraint in order to preserve coolant speed, which at the same time preserves Reynolds numbers and other flow regime indicators from the real conditions.

Table 3.5. Equivalent diameter for each core region in PARET HEU model

\begin{tabular}{|c|c|c|}
\hline \multicolumn{3}{|c|}{ PARET Cylindrical Model Equivalent Diameter Table } \\
\hline Core Region & $\begin{array}{l}\text { Equivalent Hydraulic } \\
{\text { Diameter }(\mathbf{c m})^{\mathrm{a}}}\end{array}$ & $\begin{array}{c}\text { Radial mesh yielding equivalent area } \\
\text { to meshes in Fig. } 3.4 \text { and } 3.5\end{array}$ \\
\hline 1 & \multirow{17}{*}{0.254} & 2.296 \\
\hline 2 & & 1.313 \\
\hline 3 & & 1.004 \\
\hline 4 & & 1.576 \\
\hline 5 & & 1.498 \\
\hline 6 & & 1.346 \\
\hline 7 & & 0.631 \\
\hline 8 & & 0.690 \\
\hline 9 & & 0.491 \\
\hline 10 & & 0.656 \\
\hline 11 & & 0.651 \\
\hline 12 & & 1.264 \\
\hline 13 & & 1.276 \\
\hline 14 & & 1.237 \\
\hline 15 & & 0.605 \\
\hline 16 & & 0.577 \\
\hline 17 & & 0.549 \\
\hline
\end{tabular}

${ }^{a}$ Diameter computed as $(4 *$ flow cross section area) / wetted perimeter. Parallel, involute plates result in same hydraulic diameter regardless of position along plate.

For the LEU neutronics model, the radial and axial discretization were unchanged from the one previously presented for the HEU fuel. The power density profile distributions for the LEU model at beginning-of-life are provided in Tables 3.6 and 3.7. End-of-life distributions for LEU are shown in Tables 3.8 and 3.9. 
Table 3.6 Relative power distribution for the inner fuel element, LEU, beginning-of-cycle Power Level Distribution Inner Fuel Element

\begin{tabular}{|c|c|c|c|c|c|c|c|c|c|}
\hline \multicolumn{10}{|c|}{$\begin{array}{c}\text { Level Distribution Inner Fuel Element } \\
\text { Radial Mesh }\end{array}$} \\
\hline \multirow{20}{*}{$\begin{array}{l}\text { Axial } \\
\text { Mesh }\end{array}$} & No. & 1 & 2 & 3 & 4 & 5 & 6 & 7 & 8 \\
\hline & 19 & 0.706 & 0.797 & 0.898 & 0.901 & 0.887 & 0.859 & 0.790 & 0.783 \\
\hline & 18 & 0.638 & 0.673 & 0.711 & 0.700 & 0.691 & 0.713 & 0.696 & 0.699 \\
\hline & 17 & 0.596 & 0.595 & 0.594 & 0.570 & 0.569 & 0.621 & 0.624 & 0.632 \\
\hline & 16 & 0.554 & 0.531 & 0.501 & 0.466 & 0.476 & 0.544 & 0.567 & 0.570 \\
\hline & 15 & 1.017 & 0.899 & 0.795 & 0.725 & 0.743 & 0.884 & 0.989 & 1.025 \\
\hline & 14 & 1.105 & 0.960 & 0.834 & 0.761 & 0.780 & 0.926 & 1.029 & 1.065 \\
\hline & 13 & 1.343 & 1.167 & 1.013 & 0.921 & 0.951 & 1.115 & 1.226 & 1.259 \\
\hline & 12 & 1.617 & 1.400 & 1.218 & 1.116 & 1.149 & 1.350 & 1.482 & 1.526 \\
\hline & 11 & 1.750 & 1.516 & 1.319 & 1.215 & 1.247 & 1.468 & 1.613 & 1.659 \\
\hline & 10 & 1.748 & 1.521 & 1.329 & 1.220 & 1.253 & 1.470 & 1.616 & 1.664 \\
\hline & 9 & 1.735 & 1.504 & 1.307 & 1.201 & 1.235 & 1.450 & 1.595 & 1.641 \\
\hline & 8 & 1.574 & 1.368 & 1.191 & 1.091 & 1.119 & 1.317 & 1.446 & 1.484 \\
\hline & 7 & 1.296 & 1.121 & 0.971 & 0.888 & 0.912 & 1.068 & 1.172 & 1.209 \\
\hline & 6 & 1.070 & 0.923 & 0.796 & 0.724 & 0.741 & 0.877 & 0.970 & 0.997 \\
\hline & 5 & 0.988 & 0.871 & 0.761 & 0.689 & 0.703 & 0.828 & 0.919 & 0.954 \\
\hline & 4 & 0.537 & 0.509 & 0.475 & 0.441 & 0.445 & 0.505 & 0.523 & 0.535 \\
\hline & 3 & 0.569 & 0.566 & 0.557 & 0.530 & 0.528 & 0.577 & 0.581 & 0.585 \\
\hline & 2 & 0.611 & 0.638 & 0.673 & 0.649 & 0.643 & 0.663 & 0.650 & 0.656 \\
\hline & 1 & 0.674 & 0.751 & 0.841 & 0.836 & 0.823 & 0.793 & 0.721 & 0.727 \\
\hline
\end{tabular}

The regions identified by the radial mesh - the 17 "element" regions in Table 3.5 - are actually a set of independent, single channel models all of which are linked to a common point kinetics model (see Fig. 1.1). A representation of a plate model is shown in Fig. 3.7 from [8]. Note that the coolant channel is represented by a single zone. 
Table 3.7. Relative power distribution for the outer fuel element, LEU, beginning-of-cycle Power Level Distribution Outer Fuel Element

\begin{tabular}{|c|c|c|c|c|c|c|c|c|c|c|}
\hline & \multicolumn{10}{|c|}{ Radial Mesh } \\
\hline \multirow{20}{*}{$\begin{array}{l}\text { Axial } \\
\text { Mesh }\end{array}$} & No. & 9 & 10 & 11 & 12 & 13 & 14 & 15 & 16 & 17 \\
\hline & 19 & 0.821 & 0.835 & 0.873 & 0.924 & 0.892 & 0.770 & 0.526 & 0.353 & 0.293 \\
\hline & 18 & 0.733 & 0.725 & 0.703 & 0.691 & 0.660 & 0.587 & 0.441 & 0.328 & 0.282 \\
\hline & 17 & 0.648 & 0.643 & 0.596 & 0.555 & 0.526 & 0.486 & 0.397 & 0.317 & 0.279 \\
\hline & 16 & 0.584 & 0.566 & 0.511 & 0.464 & 0.438 & 0.417 & 0.363 & 0.314 & 0.281 \\
\hline & 15 & 1.034 & 0.952 & 0.797 & 0.703 & 0.667 & 0.650 & 0.611 & 0.584 & 0.558 \\
\hline & 14 & 1.060 & 0.994 & 0.835 & 0.744 & 0.712 & 0.703 & 0.677 & 0.672 & 0.646 \\
\hline & 13 & 1.271 & 1.190 & 1.017 & 0.920 & 0.892 & 0.895 & 0.886 & 0.899 & 0.871 \\
\hline & 12 & 1.535 & 1.440 & 1.239 & 1.137 & 1.121 & 1.161 & 1.223 & 1.310 & 1.292 \\
\hline & 11 & 1.658 & 1.560 & 1.348 & 1.236 & 1.228 & 1.285 & 1.371 & 1.480 & 1.462 \\
\hline & 10 & 1.668 & 1.570 & 1.355 & 1.244 & 1.237 & 1.293 & 1.381 & 1.491 & 1.474 \\
\hline & 9 & 1.648 & 1.551 & 1.339 & 1.230 & 1.217 & 1.273 & 1.352 & 1.457 & 1.442 \\
\hline & 8 & 1.492 & 1.400 & 1.203 & 1.098 & 1.078 & 1.106 & 1.151 & 1.218 & 1.199 \\
\hline & 7 & 1.205 & 1.132 & 0.966 & 0.870 & 0.834 & 0.820 & 0.784 & 0.767 & 0.732 \\
\hline & 6 & 0.997 & 0.933 & 0.785 & 0.699 & 0.664 & 0.641 & 0.605 & 0.584 & 0.554 \\
\hline & 5 & 0.960 & 0.887 & 0.743 & 0.650 & 0.608 & 0.566 & 0.507 & 0.468 & 0.438 \\
\hline & 4 & 0.544 & 0.526 & 0.474 & 0.422 & 0.389 & 0.352 & 0.280 & 0.221 & 0.193 \\
\hline & 3 & 0.598 & 0.591 & 0.544 & 0.498 & 0.458 & 0.397 & 0.286 & 0.195 & 0.161 \\
\hline & 2 & 0.667 & 0.664 & 0.634 & 0.612 & 0.563 & 0.473 & 0.310 & 0.192 & 0.151 \\
\hline & 1 & 0.747 & 0.763 & 0.785 & 0.813 & 0.763 & 0.617 & 0.369 & 0.209 & 0.157 \\
\hline
\end{tabular}

One method of modeling HFIR would be to compute an average fuel thickness, create an "average" fuel plate - an equivalent involute plate with a constant fuel thickness along its length equal to the volumetric average of the real fuel distribution - and use that plate in each of the cylindrical regions representing the reactor core. For such a plate, PARET requires the input of a fuel half thickness and a plate half thickness. The computer code assumes symmetry about the center plane of the 'flat' plate; however, the HFIR fuel plate is not symmetric about the center plane. An average fuel thickness is calculated for each type of plate, and a new thickness is averaged between the two fuel elements weighted with the number of plates in each fuel element. A given fuel plate can be treated as two different half-plates, where each has a different fuel meat thickness. Then the correct temperature profile across the thickness of the plate is obtained (provided that the ratio of plate thickness to radius of curvature is $<0.1$ ). 
Table 3.8. Relative power distribution for the inner fuel element, LEU, end-of-cycle Power Level Distribution Inner Fuel Element

\begin{tabular}{|c|c|c|c|c|c|c|c|c|c|}
\hline & \multicolumn{9}{|c|}{ Radial Mesh } \\
\hline \multirow{20}{*}{$\begin{array}{l}\text { Axial } \\
\text { Mesh }\end{array}$} & No. & 1 & 2 & 3 & 4 & 5 & 6 & 7 & 8 \\
\hline & 19 & 0.495 & 0.650 & 0.835 & 0.881 & 0.877 & 0.816 & 0.713 & 0.725 \\
\hline & 18 & 0.485 & 0.616 & 0.749 & 0.760 & 0.753 & 0.730 & 0.664 & 0.671 \\
\hline & 17 & 0.472 & 0.578 & 0.659 & 0.642 & 0.638 & 0.656 & 0.616 & 0.627 \\
\hline & 16 & 0.460 & 0.531 & 0.562 & 0.529 & 0.533 & 0.578 & 0.564 & 0.575 \\
\hline & 15 & 0.858 & 0.926 & 0.888 & 0.804 & 0.813 & 0.936 & 0.982 & 1.026 \\
\hline & 14 & 0.888 & 0.944 & 0.885 & 0.794 & 0.807 & 0.926 & 0.983 & 1.045 \\
\hline & 13 & 0.977 & 1.083 & 1.037 & 0.935 & 0.944 & 1.067 & 1.114 & 1.186 \\
\hline & 12 & 1.050 & 1.229 & 1.217 & 1.096 & 1.100 & 1.231 & 1.265 & 1.360 \\
\hline & 11 & 1.077 & 1.293 & 1.302 & 1.175 & 1.179 & 1.310 & 1.344 & 1.447 \\
\hline & 10 & 1.075 & 1.295 & 1.307 & 1.181 & 1.184 & 1.320 & 1.357 & 1.454 \\
\hline & 9 & 1.075 & 1.295 & 1.299 & 1.171 & 1.177 & 1.308 & 1.343 & 1.445 \\
\hline & 8 & 1.048 & 1.224 & 1.210 & 1.091 & 1.098 & 1.228 & 1.263 & 1.357 \\
\hline & 7 & 0.968 & 1.071 & 1.028 & 0.925 & 0.933 & 1.055 & 1.103 & 1.175 \\
\hline & 6 & 0.882 & 0.936 & 0.871 & 0.778 & 0.789 & 0.910 & 0.966 & 1.023 \\
\hline & 5 & 0.858 & 0.918 & 0.871 & 0.782 & 0.795 & 0.907 & 0.960 & 1.005 \\
\hline & 4 & 0.457 & 0.528 & 0.551 & 0.520 & 0.521 & 0.563 & 0.552 & 0.564 \\
\hline & 3 & 0.468 & 0.571 & 0.639 & 0.623 & 0.621 & 0.643 & 0.604 & 0.612 \\
\hline & 2 & 0.477 & 0.608 & 0.725 & 0.733 & 0.730 & 0.720 & 0.655 & 0.658 \\
\hline & 1 & 0.489 & 0.637 & 0.807 & 0.849 & 0.850 & 0.798 & 0.696 & 0.700 \\
\hline
\end{tabular}

For this work though, the cylindrical-core-geometry option was not chosen. If the "nested tube" option in PARET is selected rather than the "cylindrical" option, then the variable fuel meat transverse width can be modeled by the use of multiple channels. The "nested tube" option requires rectangular geometry description for the reactor core. However, in PARET, the geometric configuration of the core, cylindrical or rectangular, is only used in the determination of the total heat transfer area and, consequently, the total heat flux. To accommodate the rectangular geometry requirement, the "along-the-plate" fuel thickness variation in the HFIR fuel plates can be modeled by creating separate plate models for each of the PARET "elements" with the fuel thickness in a given plate model corresponding to the radial location along the real, HFIR involute plate. Interactions between channels are ignored. Each portion of the involute plate can be modeled as a flat plate with little error because when the tube thickness to radius ratio is less than 0.1 as the temperature profile across the thickness of the tube approaches the flat plate solution. 
Table 3.9. Relative power distribution for the outer fuel element, LEU, end-of-cycle Power Level Distribution Outer Fuel Element

\begin{tabular}{|c|c|c|c|c|c|c|c|c|c|c|}
\hline & \multicolumn{10}{|c|}{ Radial Mesh } \\
\hline \multirow{20}{*}{$\begin{array}{l}\text { Axial } \\
\text { Mesh }\end{array}$} & No. & 9 & 10 & 11 & 12 & 13 & 14 & 15 & 16 & 17 \\
\hline & 19 & 0.749 & 0.774 & 0.872 & 0.996 & 1.040 & 0.978 & 0.740 & 0.541 & 0.463 \\
\hline & 18 & 0.694 & 0.699 & 0.737 & 0.778 & 0.797 & 0.777 & 0.649 & 0.516 & 0.449 \\
\hline & 17 & 0.638 & 0.633 & 0.632 & 0.628 & 0.633 & 0.642 & 0.585 & 0.494 & 0.441 \\
\hline & 16 & 0.581 & 0.567 & 0.543 & 0.514 & 0.517 & 0.545 & 0.529 & 0.478 & 0.437 \\
\hline & 15 & 1.037 & 0.956 & 0.840 & 0.761 & 0.754 & 0.813 & 0.871 & 0.876 & 0.851 \\
\hline & 14 & 1.052 & 0.957 & 0.841 & 0.772 & 0.769 & 0.827 & 0.905 & 0.922 & 0.895 \\
\hline & 13 & 1.199 & 1.087 & 0.980 & 0.910 & 0.909 & 0.977 & 1.047 & 1.025 & 0.983 \\
\hline & 12 & 1.379 & 1.245 & 1.139 & 1.063 & 1.065 & 1.142 & 1.200 & 1.127 & 1.071 \\
\hline & 11 & 1.463 & 1.318 & 1.215 & 1.137 & 1.139 & 1.218 & 1.272 & 1.178 & 1.115 \\
\hline & 10 & 1.473 & 1.323 & 1.220 & 1.143 & 1.141 & 1.224 & 1.279 & 1.180 & 1.117 \\
\hline & 9 & 1.458 & 1.318 & 1.212 & 1.133 & 1.134 & 1.215 & 1.270 & 1.172 & 1.112 \\
\hline & 8 & 1.374 & 1.239 & 1.132 & 1.058 & 1.059 & 1.135 & 1.191 & 1.119 & 1.065 \\
\hline & 7 & 1.187 & 1.078 & 0.966 & 0.902 & 0.903 & 0.969 & 1.031 & 1.004 & 0.965 \\
\hline & 6 & 1.040 & 0.947 & 0.830 & 0.759 & 0.754 & 0.808 & 0.878 & 0.890 & 0.861 \\
\hline & 5 & 1.017 & 0.935 & 0.821 & 0.738 & 0.725 & 0.767 & 0.819 & 0.814 & 0.784 \\
\hline & 4 & 0.572 & 0.553 & 0.524 & 0.493 & 0.491 & 0.507 & 0.482 & 0.425 & 0.385 \\
\hline & 3 & 0.619 & 0.612 & 0.610 & 0.603 & 0.596 & 0.593 & 0.516 & 0.420 & 0.372 \\
\hline & 2 & 0.675 & 0.671 & 0.710 & 0.741 & 0.747 & 0.709 & 0.564 & 0.425 & 0.370 \\
\hline & 1 & 0.725 & 0.742 & 0.839 & 0.945 & 0.976 & 0.889 & 0.641 & 0.448 & 0.378 \\
\hline
\end{tabular}

Peak fuel temperature should be more accurately calculated with the "nested tube" model than with the "cylindrical" model. However the requirement that the PARET fuel plate model be symmetrical when the HFIR fuel plate is not symmetrical coupled with the thinness of the HFIR plate could render either representation as being equally acceptable. The asymmetry of the HFIR fuel plates can be treated as two different half-plates.

Fig. 3.8 illustrates the conversion of a HFIR involute plate to the "nested tube" model. The approximation represented in Fig. 3.8 is appropriate when the plate thickness to segment-length ratio is much less than one. That is, heat conduction and temperature variation through the plate is much greater than the variation between the segments that lie along the plate as shown in Fig. 3.8 (segments divided by bars). Note that these segment lengths are directly related to radial distance from the center of the core as well as the absolute difference between segment boundaries, i.e. in an involute plate, equal radial intervals generate different along-the-plate segment lengths. 


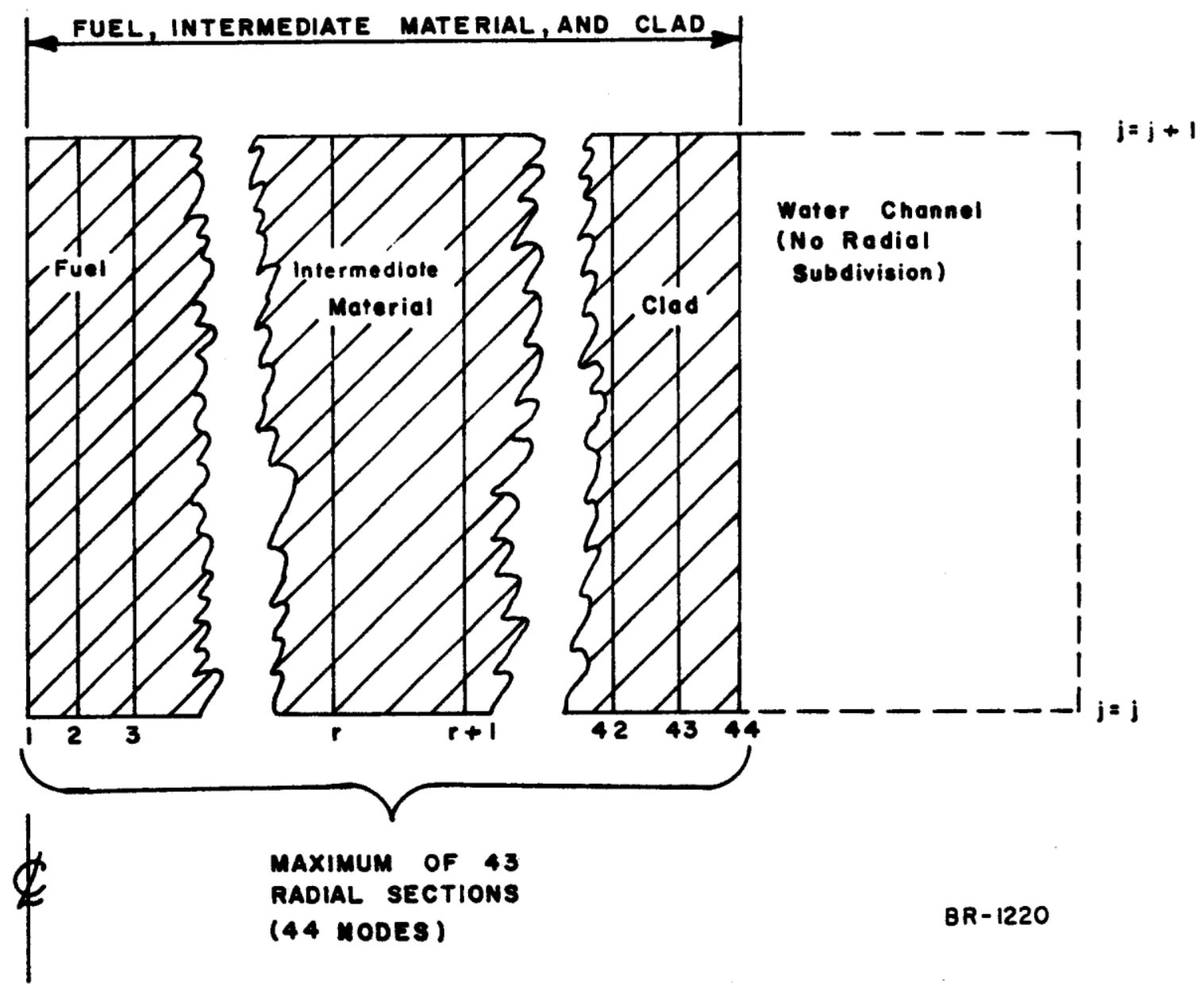

Fig. 3.7. Plate radial subsectioning used in thermal hydraulic calculation in PARET (same plate in each radial element in reactor model).

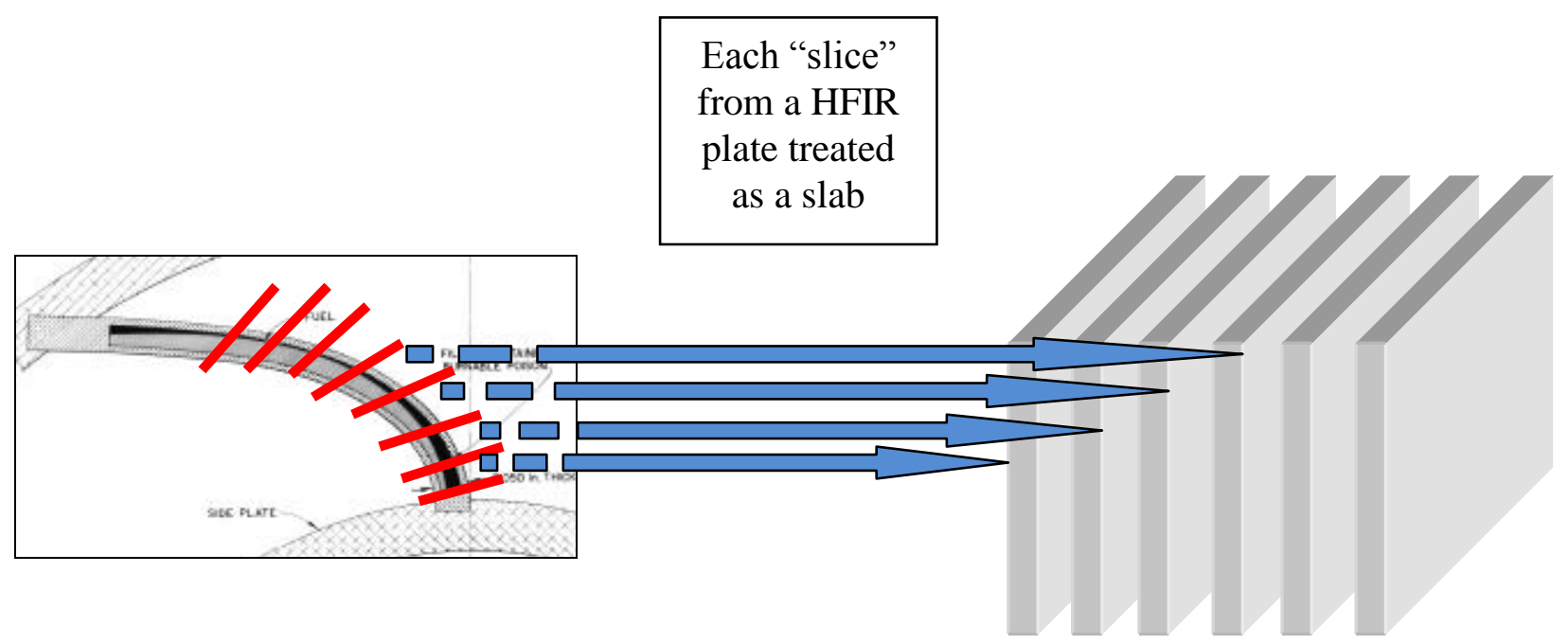

Fig. 3.8. Conversion of HFIR involute plate to "nested tube" model. 
A fuel "meat" thickness must be identified for each of the 17 plate models corresponding to the 17 slab elements that have been partitioned from an inner plate ( 8 regions) and an outer plate ( 9 regions).

Figure 3.9 shows the fuel meat thickness variation in inner fuel plates for both HEU and LEU fuels.

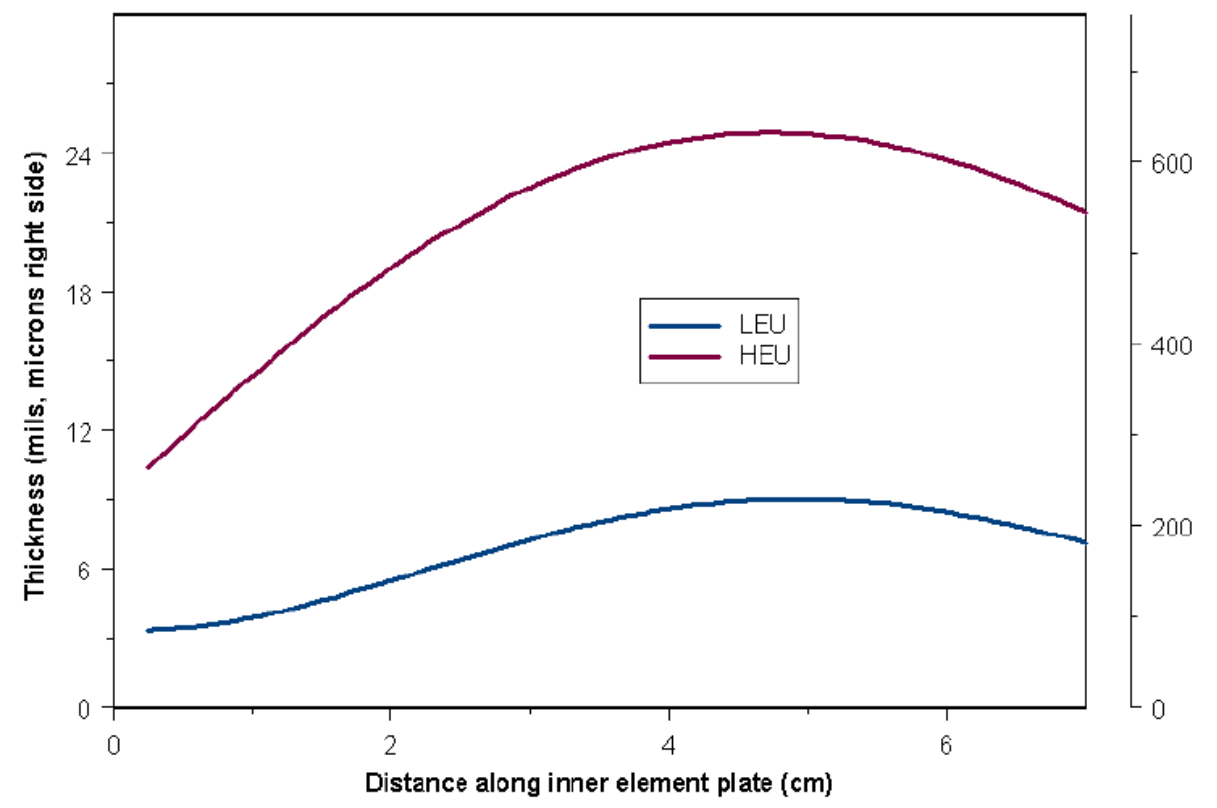

Fig. 3.9. Fuel thicknesses inside plates for inner element.

Fig. 3.10 shows the fuel meat thickness variation inside the outer element fuel plates. The radial mesh spacing in Table 3.5 identifies the location along the plates at which the fuel thicknesses are selected for the 17 elements in the "nested tube" model. The width of the slabs is the quotient of the area of the zone divided by the plate thickness. The equivalent hydraulic diameter is the same as in Table 3.5. Derived values are in Table 3.10.

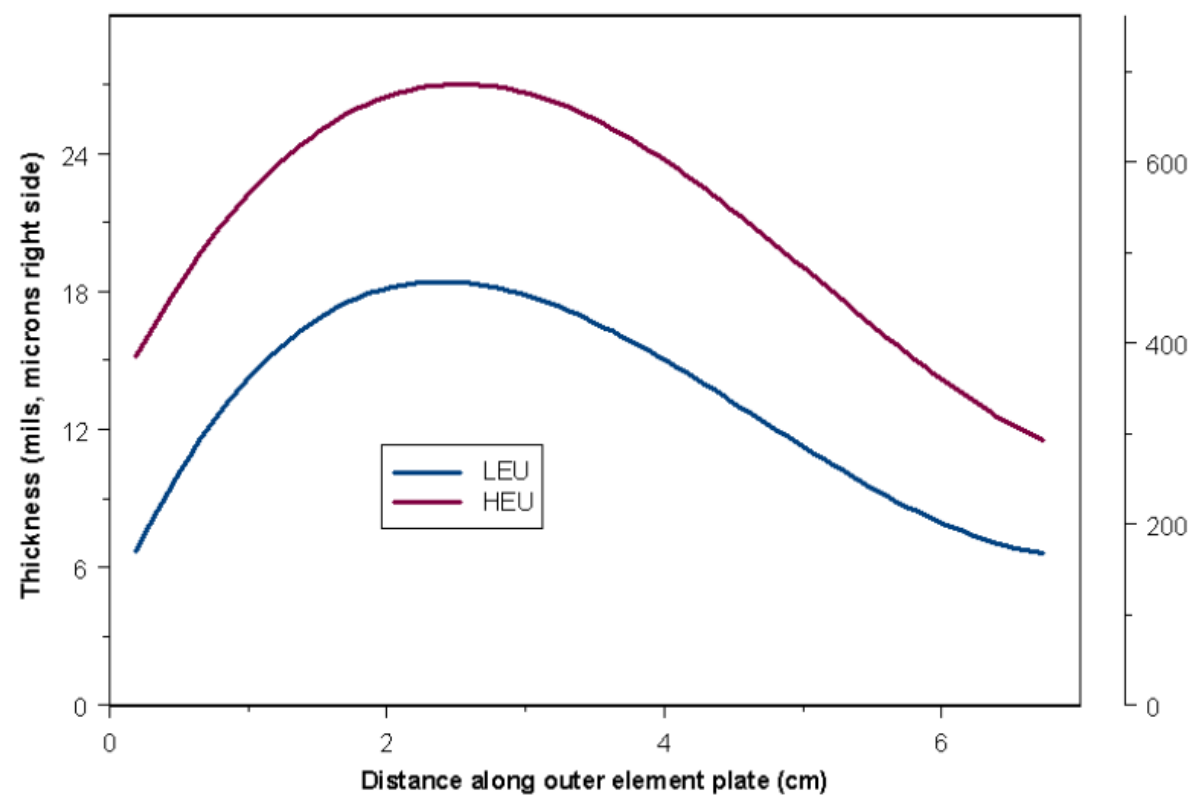

Fig. 3.10. Fuel thicknesses inside plates for outer fuel elements. 
Table 3.10. Nested tube model dimensions

\begin{tabular}{|c|c|c|c|c|c|}
\hline \multicolumn{6}{|c|}{ PARET Nested Tube Model } \\
\hline \multirow{2}{*}{$\begin{array}{l}\text { Core } \\
\text { Region }\end{array}$} & \multirow{2}{*}{$\begin{array}{l}\text { Plate Equiv. Hyd. } \\
\text { Diam. }(\mathrm{cm})^{\mathrm{a}}\end{array}$} & \multicolumn{2}{|c|}{ Slab Dimensions (cm) } & \multicolumn{2}{|c|}{$\begin{array}{c}\text { Plate fuel thickness } \\
\text { (microns) }\end{array}$} \\
\hline & & Thickness & Length & HEU & $\overline{\text { LEU }}$ \\
\hline 1 & \multirow{17}{*}{0.254} & 2.296 & 7.21 & 259 & 127 \\
\hline 2 & & 1.313 & 18.55 & 295 & 127 \\
\hline 3 & & 1.004 & 25.83 & 394 & 188 \\
\hline 4 & & 1.576 & 35.87 & 521 & 257 \\
\hline 5 & & 1.498 & 41.93 & 620 & 300 \\
\hline 6 & & 1.346 & 51.36 & 625 & 310 \\
\hline 7 & & 0.631 & 58.53 & 546 & 277 \\
\hline 8 & & 0.690 & 67.17 & 472 & 213 \\
\hline 9 & & 0.491 & 70.51 & 389 & 229 \\
\hline 10 & & 0.656 & 75.36 & 396 & 251 \\
\hline 11 & & 0.651 & 78.43 & 429 & 356 \\
\hline 12 & & 1.264 & 84.48 & 584 & 457 \\
\hline 13 & & 1.276 & 88.60 & 688 & 457 \\
\hline 14 & & 1.237 & 96.42 & 648 & 401 \\
\hline 15 & & 0.605 & 102.45 & 526 & 259 \\
\hline 16 & & 0.577 & 110.14 & 373 & 170 \\
\hline 17 & & 0.549 & 113.86 & 292 & 135 \\
\hline
\end{tabular}

Finally, it is also necessary to discretize the fuel slab and its cladding such that heat transfer calculations can be appropriately done. Figure 3.11 shows the adopted discretization scheme.

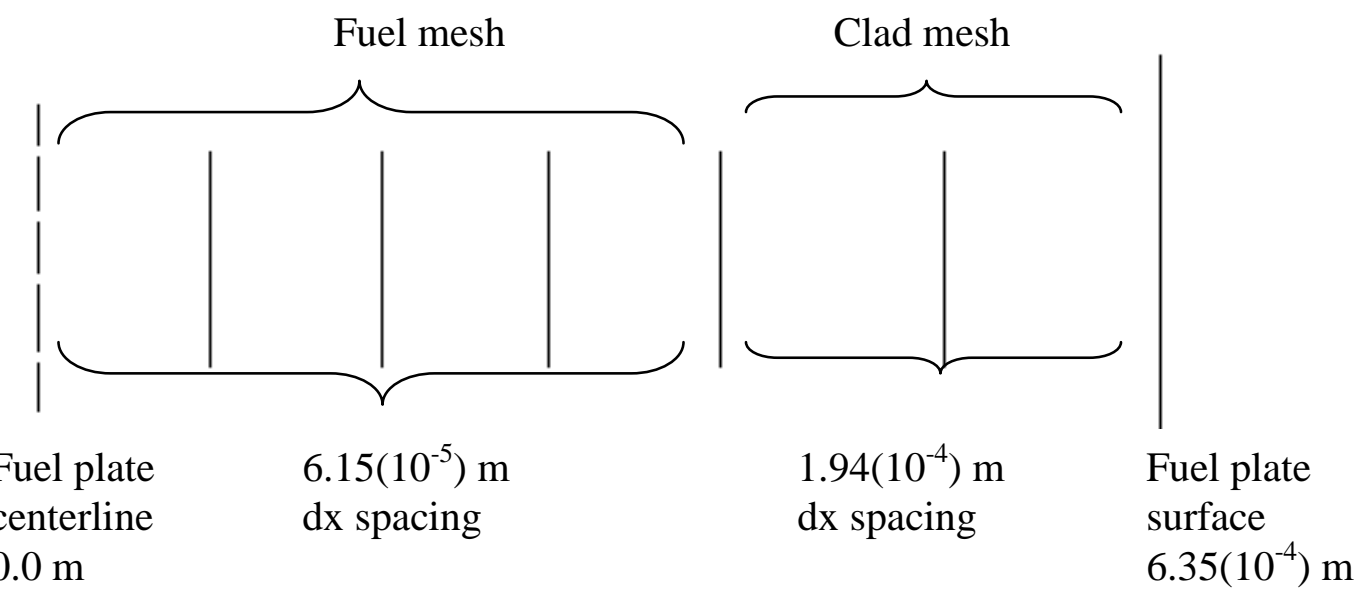

Fig. 3.11. Fuel plate discretization.

PARET requires as input the total volume of fuel in the reactor as well as the total area of flow. The first calculation is relatively simple, based on the known mass of fuel per plate, the total number of plates and the density of the fuel. The second calculation requires a more heuristic approach. It is known that the channel thickness is the same as the fuel plate thickness, then the area of flow must be half of the total area available between the two fuel elements. Table 3.11 summarizes the geometric properties of the fuel and the core. 
Table 3.11. Core and fuel plate geometric data HFIR fuel plate geometric data

\begin{tabular}{c|c|c}
\hline Component & HEU & LEU \\
\hline Total fuel 'meat' volume in core & $0.00980 \mathrm{~m}^{3}$ & $0.00534 \mathrm{~m}^{3}$ \\
\hline Nominal fuel half thickness & $0.2460 \mathrm{~mm}$ & $0.1341 \mathrm{~mm}$ \\
\hline Nominal "intermediate" filler half thickness & $0.3810 \mathrm{~mm}$ & $0.3810 \mathrm{~mm}$ \\
\hline Plate half thickness & $0.6350 \mathrm{~mm}$ & $0.6350 \mathrm{~mm}$ \\
\hline Fuel - clad gap & $0.0 \mathrm{~m}$ & $0.0 \mathrm{~m}$ \\
\hline Active fuel length & $0.508 \mathrm{~m}$ & $0.508 \mathrm{~m}$ \\
\hline Center of fuel - center of coolant channel distance & $1.27 \mathrm{~cm}$ & $1.27 \mathrm{~cm}$ \\
\hline Total area of flow & $0.0498 \mathrm{~m}^{2}$ & $0.0498 \mathrm{~m}^{2}$ \\
\hline $\begin{array}{c}\text { Fraction of fission heat deposited } \\
\text { in the fuel assembly }\end{array}$ & 0.975 & 0.975 \\
\hline \begin{tabular}{c} 
Con \\
\hline
\end{tabular}
\end{tabular}

\subsection{Core Materials Description}

The reactor core of the HFIR operates with pressurized light water and is fueled with highly enriched uranium clad in aluminum metal and possesses a variety of control systems for criticality. It is important to define precisely the materials which make up the core in order to accurately predict property changes under transients, however, the HFIR model requires only the properties of the basic components of the core, namely, the fuel, the cladding, and the coolant. Given that PARET targets the analysis of thermal transients as part as the safety analysis, the thermal properties are defined only for the materials mentioned.

Clearly, the thermal properties of materials are different when they are at different temperatures. For this reason, PARET utilizes a system that allows this temperature variation to be taken into account. It is assumed that the property can be represented by a polynomial function with exponents ranging from -1 to 2 . Namely, the properties can be established by declaring the coefficients alpha and beta in two functions. The alpha,$(n=1,2, \ldots, 5)$ are the thermal conductivity coefficients of the material for an equation of the form $\mathrm{k}_{\mathrm{n}+1 / 2}^{\mathrm{m}}=\alpha_{1} \mathrm{~T}^{2}+\alpha_{2} \mathrm{~T}+\alpha_{3}+\alpha_{4} / \mathrm{T}$. The beta $(\mathrm{n}=1,2, \ldots, 5)$ are the volumetric heat capacity coefficients of the material for an equation of the form $\mathrm{g}_{\mathrm{n}+1 / 2}^{\mathrm{m}}=\beta_{1} \mathrm{~T}^{2}+\beta_{2} \mathrm{~T}+\beta_{3}+\beta_{4} / \mathrm{T}$.

It can be easily observed from the mathematical relations above that the conductive heat transfer coefficient and the volumetric heat capacity variation can be easily established for the specified operating conditions. Figure 3.12 shows the dependence of the conductive heat transfer coefficient on the temperature for various levels of enrichment of U-Al fuels as reported by Ref. 21 . 


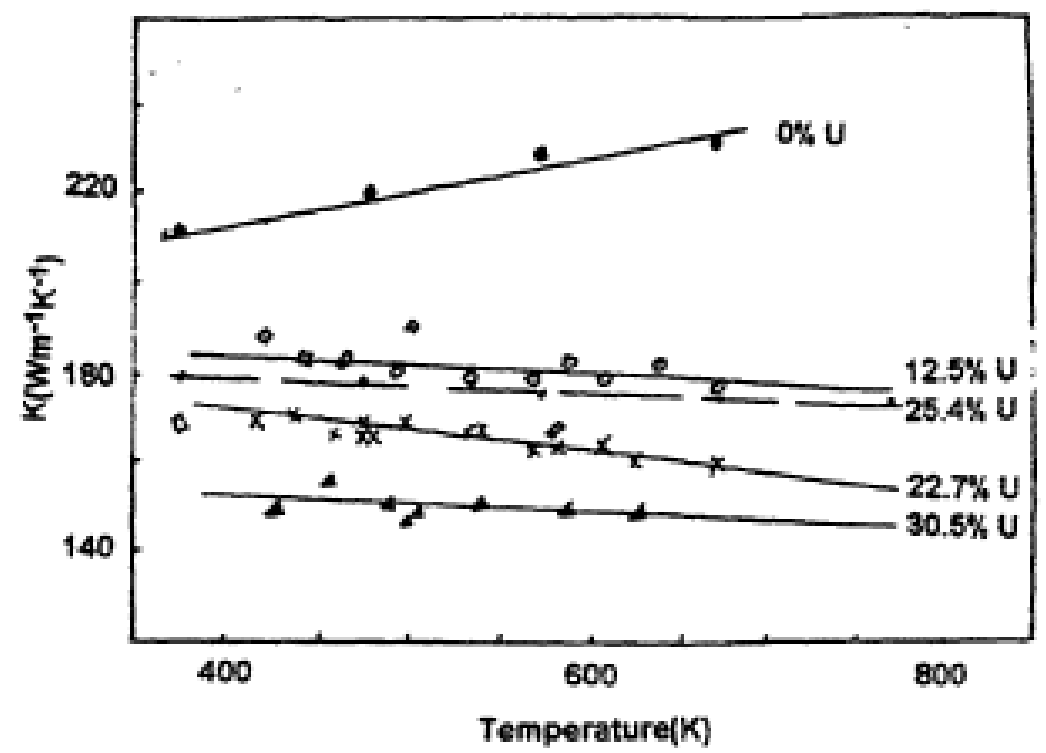

Fig. 3.12. Thermal conductivity variation as a function of temperature for typical U-Al fuel for various enrichments.

It can be inferred from the graph above that the thermal conductivity changes linearly with temperature, however the value almost seems constant over such large temperature range, especially for the high enrichment case, as it is the case with HFIR. Thus, it seems reasonable to assume a constant k coefficient. Similarly, it can be shown that the volumetric heat capacity does not change much over large temperatures, therefore constant thermal properties for the fuel plates. HFIR, though, having fuel that is a mixture of $\mathrm{U} 3 \mathrm{O} 8$ and $\mathrm{Al}$ has somewhat lower thermal conductivity than shown in Fig. 3.12. Table 3.12 summarizes the data obtained from Refs. 21 and 30 and utilized in PARET for both the fuel and the cladding. 
Table 3.12. Fuel and clad material thermal property coefficients

\begin{tabular}{c|c|c}
\hline \multicolumn{3}{c}{ HFIR fuel thermal properties } \\
\hline Coefficient & HEU Value & LEU Value (U-10Mo) \\
\hline $\begin{array}{c}\alpha_{1}, \alpha_{2}, \alpha_{4}, \alpha_{5} \\
(\mathrm{~T} \text { in Kelvin) }\end{array}$ & All 0.0 & $0.0,0.0240,0.0,0.0$ \\
\hline$\alpha_{3}$ & $\begin{array}{c}174.5 \mathrm{~W} / \mathrm{m}^{0} \mathrm{~K} \\
\text { [Ref. 30a values are } 132.8 \text { inner } \\
\text { element; } 110.0 \text { outer element] }\end{array}$ & 11.36 \\
\hline$\beta_{1}, \beta_{2}, \beta_{4}, \beta_{5}$ & All 0.0 & $2.82,-578,0,0$ \\
\hline$\beta_{3}$ & $6.81\left(10^{5}\right) \mathrm{J} / \mathrm{m}^{30} \mathrm{~K}$ & $19.4\left(10^{5}\right) \mathrm{J} / \mathrm{m}^{3} \mathrm{~K}$ \\
\hline
\end{tabular}

\section{HFIR clad thermal properties}

\begin{tabular}{c|c}
\hline Coefficient & Value \\
\hline$\alpha_{1}, \alpha_{2}, \alpha_{4}, \alpha_{5}$ & 0.0 \\
\hline$\alpha_{3}$ & $186.9 \mathrm{~W} / \mathrm{mK}$ \\
\hline$\beta_{1}, \beta_{2}, \beta_{4}, \beta_{5}$ & 0.0 \\
\hline$\beta_{3}$ & $7.64\left(10^{5}\right) \mathrm{J} / \mathrm{m}^{3} \mathrm{~K}$ \\
\hline thermal expansion coefficient & $2.43\left(10^{-5}\right) \mathrm{cm} /\left(\mathrm{cm}{ }^{\circ} \mathrm{C}\right)$ \\
\hline
\end{tabular}

For coolant thermal properties, PARET utilizes a library that includes more thermal properties than those specified for the fuel or the clad. The code only requires the input of a reference coolant density, temperature and pressure as a starting point of the transient.

\subsection{Neutronic Parameters}

The model requires the input of certain neutronic parameters of the reactor core. Since PARET is a reactor kinetics code, the amount of information necessary to be input is much less than that if the code had been a neutron diffusion or transport code, in which case cross sections would have been necessary, among other parameters. Table 3.13 contains the neutronic parameters assumed for HEU fuel. The delayed neutron fraction data are from ENDF/B-VI via the methodology described in Appendix A. The values for the parameters for low enriched uranium (LEU) fuel were also derived via the methodology described in Appendix A. ENDF/B-VII data are reported for LEU in Table 3.14. 
Table 3.13. Reactor kinetics parameters for HEU fuel

\begin{tabular}{|c|c|c|}
\hline \multicolumn{2}{|c|}{ Parameter } & Value \\
\hline \multicolumn{2}{|c|}{ No. of delayed groups $\beta_{\mathrm{i}}$ (from Appendix A) } & 6 \\
\hline \multirow{6}{*}{$\begin{array}{l}\text { relative delayed neutron } \\
\text { fraction, decay constant (from } \\
\text { Appendix A) }\end{array}$} & $\beta_{1}, \lambda_{1}\left(\mathrm{~s}^{-1}\right)$ & $0.031976,0.012495$ \\
\hline & $\beta_{2}, \lambda_{2}\left(\mathrm{~s}^{-1}\right)$ & $0.166406,0.031833$ \\
\hline & $\beta_{3}, \lambda_{3}\left(\mathrm{~s}^{-1}\right)$ & $0.161350,0.109416$ \\
\hline & $\beta_{4}, \lambda_{4}\left(\mathrm{~s}^{-1}\right)$ & $0.459789,0.317095$ \\
\hline & $\beta_{5}, \lambda_{5}\left(\mathrm{~s}^{-1}\right)$ & $0.133571,1.354406$ \\
\hline & $\beta_{6}, \lambda_{6}\left(\mathrm{~s}^{-1}\right)$ & $0.046908,8.639475$ \\
\hline \multicolumn{2}{|c|}{ Effective delayed neutron fraction $\beta_{\text {eff }}$ [BOL, EOL; from Appendix A] } & $0.00762,0.00752$ \\
\hline \multicolumn{2}{|c|}{ Prompt neutron lifetime $\Lambda\left[\mathrm{BOL}, \mathrm{EOL} ;\left(10^{-6}\right) \mathrm{s}\right.$, from Appendix A) } & 52,94 \\
\hline \multicolumn{2}{|c|}{$\begin{array}{l}\text { Fuel Doppler temperature coefficient } \\
{[\text { BOL, EOL; corrected from Ref. } 1 \dagger]}\end{array}$} & $\begin{array}{c}-2.41\left(10^{-6}\right),-2.46\left(10^{-6}\right) \\
(\delta \mathrm{k} / \mathrm{k}) /{ }^{\circ} \mathrm{C}\end{array}$ \\
\hline \multicolumn{2}{|c|}{ Coolant temperature feedback coefficient (from Ref. 19) } & $\begin{array}{c}-1.71\left(10^{-4}\right)(\delta \mathrm{k} / \mathrm{k}) / /{ }^{\circ} \mathrm{C} \\
\left(\text { at } \mathrm{T}=25^{\circ} \mathrm{C}\right)\end{array}$ \\
\hline \multicolumn{2}{|c|}{$\begin{array}{l}\text { Coolant void feedback coefficient (inner fuel element) } \\
\text { [BOL, EOL; from Ref. 1] }\end{array}$} & $\begin{array}{c}-0.243 \$ / \% \text { void } \\
-0.179 \$ / \% \text { void }\end{array}$ \\
\hline \multicolumn{2}{|c|}{$\begin{array}{l}\text { Coolant void feedback coefficient (outer fuel element) } \\
\text { [BOL, EOL; from Ref. 1] }\end{array}$} & $\begin{array}{l}-0.101 \$ / \% \text { void, } \\
-0.074 \$ 1 \% \text { void }\end{array}$ \\
\hline
\end{tabular}

Table 3.14. Reactor kinetics parameters for LEU fuel

\begin{tabular}{|c|c|c|}
\hline \multicolumn{2}{|c|}{ Parameter } & Value \\
\hline \multicolumn{2}{|c|}{ No. of delayed groups $\beta_{\mathrm{i}}($ from Appendix $\mathrm{A})$} & 6 \\
\hline \multirow{6}{*}{$\begin{array}{l}\text { relative delayed neutron } \\
\text { fraction, decay constant } \\
\text { (BOL, from Appendix A) }\end{array}$} & $\beta_{1}, \lambda_{1}\left(\mathrm{~s}^{-1}\right)$ & $0.031223,0.012502$ \\
\hline & $\beta_{2}, \lambda_{2}\left(s^{-1}\right)$ & $0.164661,0.031795$ \\
\hline & $\beta_{3}, \lambda_{3}\left(\mathrm{~s}^{-1}\right)$ & $0.160244,0.109708$ \\
\hline & $\beta_{4}, \lambda_{4}\left(\mathrm{~s}^{-1}\right)$ & $0.459758,0.318138$ \\
\hline & $\beta_{5}, \lambda_{5}\left(\mathrm{~s}^{-1}\right)$ & $0.137204,1.353875$ \\
\hline & $\beta_{6}, \lambda_{6}\left(\mathrm{~s}^{-1}\right)$ & $0.046910,8.691927$ \\
\hline \multicolumn{2}{|c|}{ Effective delayed neutron fraction $\beta_{\text {eff }}$ [BOL, EOL; from Appendix A] } & $0.00749,0.00717$ \\
\hline \multicolumn{2}{|c|}{ Prompt neutron lifetime $\Lambda\left[\mathrm{BOL}, \mathrm{EOL} ;\left(10^{-6}\right) \mathrm{s}\right.$, from Appendix A] } & 47,72 \\
\hline \multicolumn{2}{|c|}{$\begin{array}{c}\text { Fuel Doppler temperature coefficient } \\
{[\text { BOL, EOL; corrected from Ref. 1] }}\end{array}$} & $\begin{array}{c}-2.42\left(10^{-5}\right),-2.38\left(10^{-5}\right) \\
(\delta \mathrm{k} / \mathrm{k}) /{ }^{\circ} \mathrm{C}\end{array}$ \\
\hline \multicolumn{2}{|c|}{ Coolant temperature feedback coefficient (from G. Ilas, ORNL) } & $\begin{array}{c}-0.78\left(10^{-4}\right)(\delta \mathrm{k} / \mathrm{k}) /{ }^{\circ} \mathrm{C} \\
\left(\text { at } \mathrm{T}=27^{\circ} \mathrm{C}\right)\end{array}$ \\
\hline \multicolumn{2}{|c|}{$\begin{array}{l}\text { Coolant void feedback coefficient (inner fuel element) } \\
\text { [BOL, EOL; from Ref. 1] }\end{array}$} & $\begin{array}{l}-0.208 \$ / \% \text { void } \\
-0.189 \$ / \% \text { void }\end{array}$ \\
\hline \multicolumn{2}{|c|}{$\begin{array}{l}\text { Coolant void feedback coefficient (outer fuel element) } \\
\text { [BOL, EOL; from Ref. 1] }\end{array}$} & $\begin{array}{l}-0.105 \$ / \% \text { void, } \\
-0.095 \$ / \% \text { void }\end{array}$ \\
\hline
\end{tabular}

$\dagger$ R. J. Ellis, ORNL, reported that the \%dk/k in Ref. 1 should be dk/k. The heu_ref case (with fuel temp = $300 \mathrm{~K}$; all other temps $=299.8 \mathrm{~K}$ ) $->\mathrm{k}=0.99909$ at $\mathrm{BOC} ; \mathrm{k}=1.00879$ at EOC (controlled). The heu_ref case (with fuel temp $=500 \mathrm{~K}$; all other temps $=299.8 \mathrm{~K}$ ) $->\mathrm{k}=0.99861$ at BOC; $\mathrm{k}=1.00829$ at EOC (controlled). This gives the fuel temp (Doppler) coefficients for HEU of: at BOC: $-4.811 \mathrm{E}-4 \mathrm{dk}$ per $200^{\circ} \mathrm{C}=-2.41 \mathrm{E}-6$ $\mathrm{dk} / \mathrm{k} /{ }^{\circ} \mathrm{C}$ (or $-1.34 \mathrm{E}-6 \mathrm{dk} / \mathrm{k} /{ }^{\circ} \mathrm{F}$ ) and at EOC: $-4.916 \mathrm{E}-4 \mathrm{dk}$ per $200^{\circ} \mathrm{C}=-2.46 \mathrm{E}-6 \mathrm{dk} / \mathrm{k} /{ }^{\circ} \mathrm{C}$ (or $-1.37 \mathrm{E}-6 \mathrm{dk} / \mathrm{k} /{ }^{\circ} \mathrm{F}$ ). Though Doppler and moderator temperature coefficients are negative for HFIR, for PARET input, these are entered as positive values. 


\subsection{Operating Parameters}

Various parameters of operation are needed for modeling transients for the core of the HFIR. Table 3.15 includes steady state reactor operation data, however, most of these parameters will change depending on the analysis of each accident scenario being performed. Note that for equivalent flux performance at experimental facilities, the LEU fuel must operate at $100 \mathrm{MW}$ whereas the HEU fuel operates at $85 \mathrm{MW}$.

Table 3.15. Assumed operational parameters

\begin{tabular}{c|c}
\hline Parameter & Nominal Operating Data \\
\hline Power & $85 \mathrm{MW}(\mathrm{HEU}) ; 100 \mathrm{MW}(\mathrm{LEU})$ \\
\hline Inlet Pressure & $3.227 \mathrm{MPa}$ \\
\hline Outlet Pressure & $2.482 \mathrm{MPa}$ \\
\hline Temperature & $49^{\circ} \mathrm{C}$ \\
\hline Reference Coolant Density & $993.0 \mathrm{~kg} / \mathrm{m}^{3}$ \\
\hline Coolant primary mass flux & $2.088\left(10^{4}\right) \mathrm{kg} / \mathrm{cm}^{2} \mathrm{~s}$ \\
\hline Core average heat flux & $2.0808\left(10^{6}\right) \mathrm{W} / \mathrm{m}^{2}(\mathrm{HEU}) ; 2.448\left(10^{6}\right) \mathrm{W} / \mathrm{m}^{2}(\mathrm{LEU})$ \\
\hline
\end{tabular}

\subsection{Control Systems}

The control system of the HFIR is composed of the control cylinder and the safety plates. The control cylinder is a movable cylinder which is located between the beryllium reflector and the outer fuel element and is inserted from the bottom of the reactor. The safety plates consist of four plates that are quadrants of a cylinder of larger inner diameter than the control cylinder and are inserted in the core from the top of the reactor. Each safety plate is independent of the other plates, and only one plate is necessary to scram the reactor at any fuel cycle stage. Since PARET does not consider these three dimensional effects of the control systems, it is sufficient to establish rod worth at certain locations along the core. The system also requires the input of the nominal control rod insertion speed and the delayed time from reactor scram to start of insertion.

In addition, PARET was constructed such that the user can specify external reactivity insertions (i.e. control rod drop) or actually scram the reactor as a consequence of certain limit being exceeded (overpower, underflow of coolant). Furthermore, the user is also able to specify hydrodynamic changes in order to explore the reactivity feedback effect of changes as such primary coolant pressure changes and mass flux changes. Notice in this case, the control rod worth is specified as a function of length inserted. In this case, PARET assumes linearity between the reactivity inserted as a function of time between two points. Then, a non linear relation may be input with the use of more than one pair of data points. Tables 3.16 and 3.17 provide data regarding operation of the control system. 
Table 3.16. Control systems data for HEU model

\begin{tabular}{c|c}
\hline Parameter & Value \\
\hline Safety plate insertion rate & $1.524 \mathrm{~m} / \mathrm{s}$ \\
\hline Time delay of rod drop & $0.01 \mathrm{~s}$ \\
\hline Overpower trip & HEU 89.0 MW; LEU 105 MW \\
\hline Low flow trip & $76.9 \%$ of nominal full power flow \\
\hline Safety plate worth & $-\$ 15.00$ \\
\hline Length of plate where this worth is reached & $0.508 \mathrm{~m}$ \\
\hline
\end{tabular}

Table 3.17. Control systems reactivity worth for HEU fuel

\begin{tabular}{cc|c|c}
\hline \multicolumn{2}{c}{ Control/safety plate position } & \multicolumn{2}{c}{$\begin{array}{c}\text { Differential reactivity worth } \\
\text { (combined control and safety plates; \$inch) }\end{array}$} \\
\hline (inches withdrawn) & $(\mathbf{c m}$ from top) & HEU $^{\mathbf{a}}$ & LEU $^{\mathbf{b}}$ \\
\hline 16 & 27.94 & 3.17 & 2.44 \\
\hline 17 & 25.4 & 3.00 & - \\
\hline 18 & 22.86 & 2.79 & 2.76 \\
\hline 19 & 20.32 & 2.57 & - \\
\hline 20 & 17.78 & 2.31 & 2.44 \\
\hline 21 & 15.24 & 2.06 & - \\
\hline 22 & 12.7 & 1.80 & - \\
\hline 23 & 10.16 & 1.50 & 1.06 \\
\hline 24 & 7.62 & 1.20 & - \\
\hline 25 & 5.08 & 0.91 & 0.65 \\
\hline 26 & 2.54 & 0.66 & - \\
\hline 27 & 0 & 0.40 & \\
\hline
\end{tabular}

${ }^{\mathrm{a}}$ Ref. 26a.

${ }^{\mathrm{b}}$ Ref. 1a.

Since control/safety element differential worth for LEU fuel is essentially the same as HEU fuel, the HEU worth values were used in LEU studies. The difference in worth at 16 inches withdrawn is likely due to differing critical configurations at beginning-of-life for the two fuels.

\subsection{Thermal Hydraulic Parameters}

PARET requires the input of certain hydrodynamic and heat-transfer data to the model; some related to the geometry of the reactor core. Table 3.18 shows the geometric data and assumptions input to PARET calculations reported subsequently. 
Table 3.18. Thermal hydraulic data and correlations used

\begin{tabular}{c|c}
\hline Parameter & Value \\
\hline Inlet non-fueled length & $0.0508 \mathrm{~m}$ \\
\hline Outlet non-fueled length & $0.0508 \mathrm{~m}$ \\
\hline Inlet to plenum area ratio & 0.5 \\
\hline Outlet to plenum area ratio & 0.5 \\
\hline Length inlet plenum & $>1.0 \mathrm{~m}$ \\
\hline Length outlet plenum & $>1.0 \mathrm{~m}$ \\
\hline Single phase correlation & Sieder Tate \\
\hline Two phase correlation & McAdams \\
\hline Transient two phase scheme & Original Model \\
\hline DNB and flow stability correlation & Original DNB \\
\hline Single phase heat transfer subroutine & Original \\
\hline Average core heat flux & HEU $4.035\left(10^{5}\right) \mathrm{W} / \mathrm{m}^{2}$ \\
(used by certain correlations only) & LEU $4.747\left(10^{5}\right) \mathrm{W} / \mathrm{m}^{2}$ \\
\hline
\end{tabular}

\subsection{Channel Dependent Flow Rates}

In [9], the author notes that the output of the PLTEMP [29] computer program is needed to establish relative flow rates among the channels of the nested tube model. For HFIR, the HFIR Steady State Heat Transfer Code (HSSHTC) [30] provides the flow rate data (as well as other parameters) that correspond to the data generated by PLTEMP for various reactors studied by the RERTR program.

The involute plate design for HFIR was chosen, in part, to assure that the coolant flow rate through the core would not be position dependent - the coolant channel-to-fuel plate area ratio is constant throughout the core. If one is only interested in transient response at beginning-of-life, the detailed core representation discussed in this section is not needed. Only the hot channel need be identified from the neutronics calculation and then only that single channel modeled. A second, "average" channel is needed for reactivity feedback from core heatup. However, given that the power distribution changes over time during a fuel cycle and given that phenomena such as oxide growth, radiation swelling, thermal-induced bowing of fuel plates, fuel clad interactions and other physical phenomena occur, then if one wishes to calculate the transient response at various times during the fuel cycle, the multichannel representation developed in this section is useful. Unlike beginning-of-life, due to the various factors, it may not be obvious which of the channels will be limiting in terms of peak temperature. Having a multichannel representation allows one to couple the output of timedependent neutronics calculations and the output from plate modeling codes such as PLTEMP and HSSHTC directly to PARET with a minimum of effort from the user. Still, of course, it will be results from a single channel - the one with the highest coolant and/or fuel temperature - that will ultimately be of interest to the user.

Experience with the HSSHTC program has shown that flow rates along an involute plate in HFIR can vary by as much as $10 \%$ at end-of-cycle. This phenomena has not been included in the analyses that will be reported in the next section but could be included in future analyses with a minimum of effort. 


\subsection{RESULTS OF CALCULATIONS}

Transients were analyzed for each HEU and LEU fuel type, and the results are plotted in the same graph, such that a comparison can be easily done. In some cases, the transients analyzed were compared to published data from the most recent Updated Safety Analysis Report (USAR) of the HFIR to further benchmark the code. In the analysis of the safety systems of the HFIR, the decrease in primary flow rate transient was studied. There are multiple scenarios within each category. The initial conditions prescribed for each scenario are detailed in the Updated Safety Analysis Report (USAR) of the HFIR [27, 28].

This family of transients refers to the sudden reduction or loss of cooling capacity in the reactor core. Various transients related to decrease in primary flow are documented in the USAR section 15.3.3 and include considerations of a loss of off-site power, primary coolant pump coast down, primary coolant pump shaft seizure and blockages of fuel element coolant channels. For this work, only the primary coolant pump shaft seizure was considered. It is defined as follows:

A mechanical failure within the primary pumps could cause a pump shaft to shear or seize. The transient resulting from this failure is similar to a single pump coastdown except that the reduction in flow is immediate. Also, a mechanical pump failure prevents operation of the associated pony motor. Primary pump seizures are virtually unknown in the power reactor industry, so this event is assumed to be an infrequent event.

[27a, p. 15.3.3-2]

Because primary pump seizure represents the most severe case of flow reduction, it was chosen for study. Table 4.1 summarizes the parameters used in this problem. Additional details regarding the description of the transient are provided subsequently.

Table 4.1. Primary coolant pump seizure initial and boundary conditions HFIR Primary Coolant Pump Seizure

\begin{tabular}{c|c}
\hline Parameter & Value \\
\hline Transient time & $100.0 \mathrm{~s}$ \\
\hline Reactivity insertion & None from control system; no SCRAM \\
\hline \multirow{2}{*}{ Boundary conditions } & $\$ 0.0$ at $0.0 \mathrm{~s}$ \\
& 2.0 at $100 \mathrm{~s}$ \\
\hline Flow rate & $2.044\left(10^{4}\right)$ from $0.0 \mathrm{~s}-10.0 \mathrm{~s}$ \\
$\left(\mathrm{~kg} / \mathrm{m}^{2} \mathrm{~s}\right)$ & $1.589\left(10^{4}\right)$ from $10.0 \mathrm{~s}-100.0 \mathrm{~s}$ \\
\hline Time step & $10^{-3}(0.0 \mathrm{~s}-9.0 \mathrm{~s})$ \\
$(\mathrm{s})$ & $10^{-4}(9.0 \mathrm{~s}-29.0 \mathrm{~s})$ \\
& $10^{-3}(29.0 \mathrm{~s}-100.0 \mathrm{~s})$ \\
\hline
\end{tabular}


A primary pump seizure is assumed to result in an immediate drop in flow, resulting in a lack of heat removal from the core until a reactor scram, if required, can occur. This event results in a decrease in margin to critical heat flux. Possible mitigating actions for a primary pump seizure include automatic closure of the failed pump outlet check valve and the reactor scram. Letdown block valve closure is not important because a depressurization does not occur during this event. Failure of the check valve to close after the pump seizes results in some backflow of coolant through the pump body. This failure reduces the flow available to the core from the remaining two pumps. The frequency of the pump seizure/check valve failure event is approximately $1 \times 10^{-6}$ per year. Nonetheless, the results of this event are included in the discussion of the bounding infrequent event. Though a SCRAM function would be initiated in such an event, the results that are presented ... show that this mitigating function is not needed because the process variables do not exceed the limiting safety system setting (LSSS) values, even if the pump outlet check valve also fails. Thus, a reactor scram failure does not need to be considered and (is not included in the model of this accident.)

To analyze the pump seizure event, the following assumptions are made:

1. The speed of the primary coolant pump is assumed to change from full speed to zero speed within $0.01 \mathrm{~s}$ to model an almost instantaneous pump seizure event.

2. The effects of reactivity feedback (with conservative uncertainties applied) are included in the computations.

3. No credit is taken for any control system functions (electric motor servo or fast air motor). The control cylinder is assumed to be stationary throughout the event.

4. The normal secondary actions that would follow a reactor scram are assumed to occur during the event. However, prior to reactor scram, the secondary system temperature control valve is not allowed to open beyond the steady-state position that it was at prior to the initiating event.

5. The check valve downstream of the seized primary coolant pump may be assumed to fail to close.

6. The initial conditions considered in these analyses are [27a, p. 15.3.3-21, -22]:

- $\quad$ Reactor power = HEU 87.6 MW, LEU 103 MW

- Reactor inlet temperature $=126.2^{\circ} \mathrm{F}\left(52.33^{\circ} \mathrm{C}\right)$

- $\quad$ Reactor inlet pressure $=406.0$ psig $(420.7$ psia [2.9Mpa] $)$

- Secondary basin temperature $=88.2^{\circ} \mathrm{F}$

- $\quad$ Primary flow rate $=15,840 \mathrm{gpm}$

- Letdown flow rate $=\sim 120 \mathrm{gpm}$

Figs. 4.1 through 4.10 depict the power, reactivity and temperature of the fuel and the coolant for the transients. Corresponding graphs from the HFIR USAR [27] are presented for comparison. Note that the operating power of the reactor for LEU fuel is greater than that for HEU fuel. 


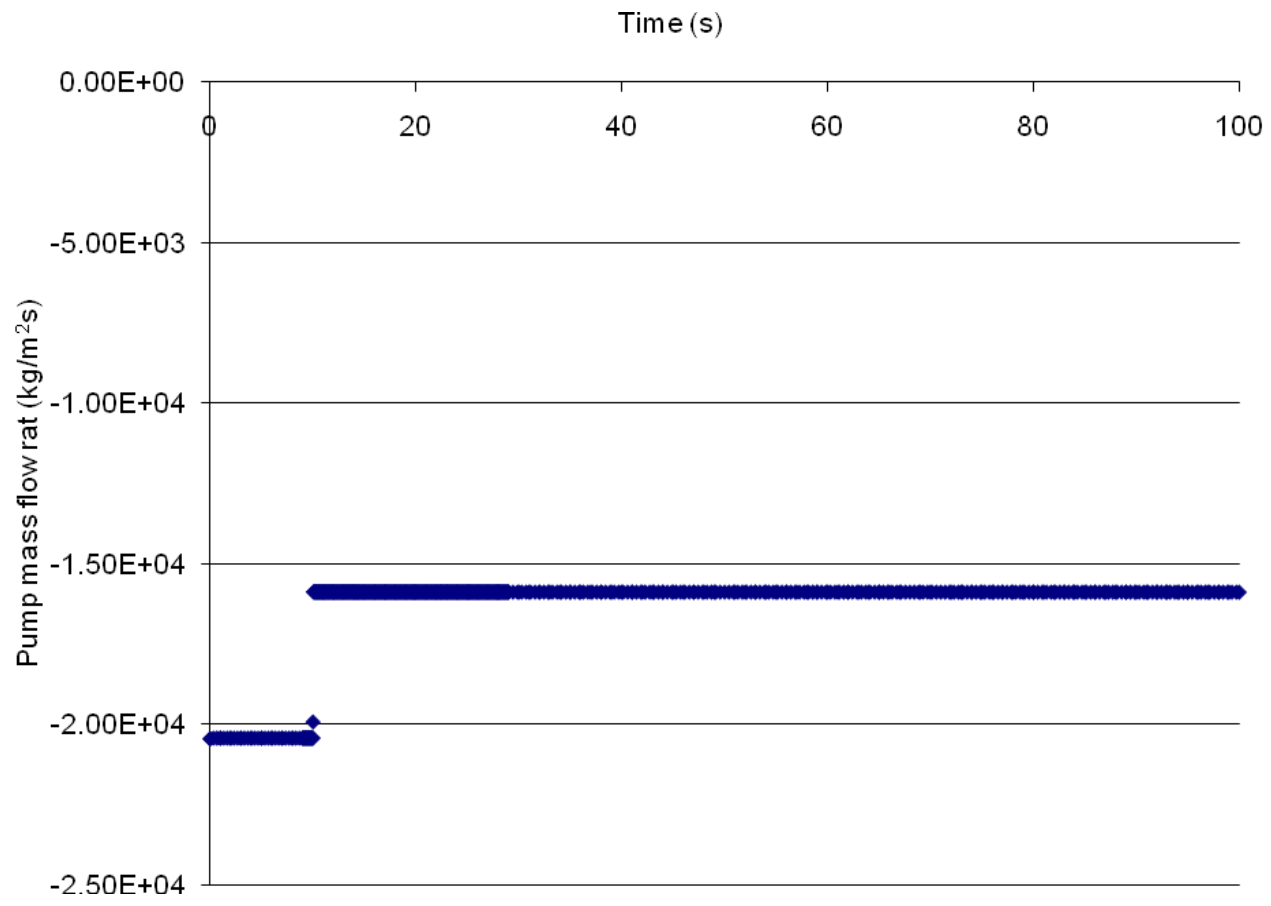

Fig. 4.1. Mass flux functions for transient in discussion. Note negative values of mass flux, as they indicate the downward direction of flow that exists in the HFIR core.

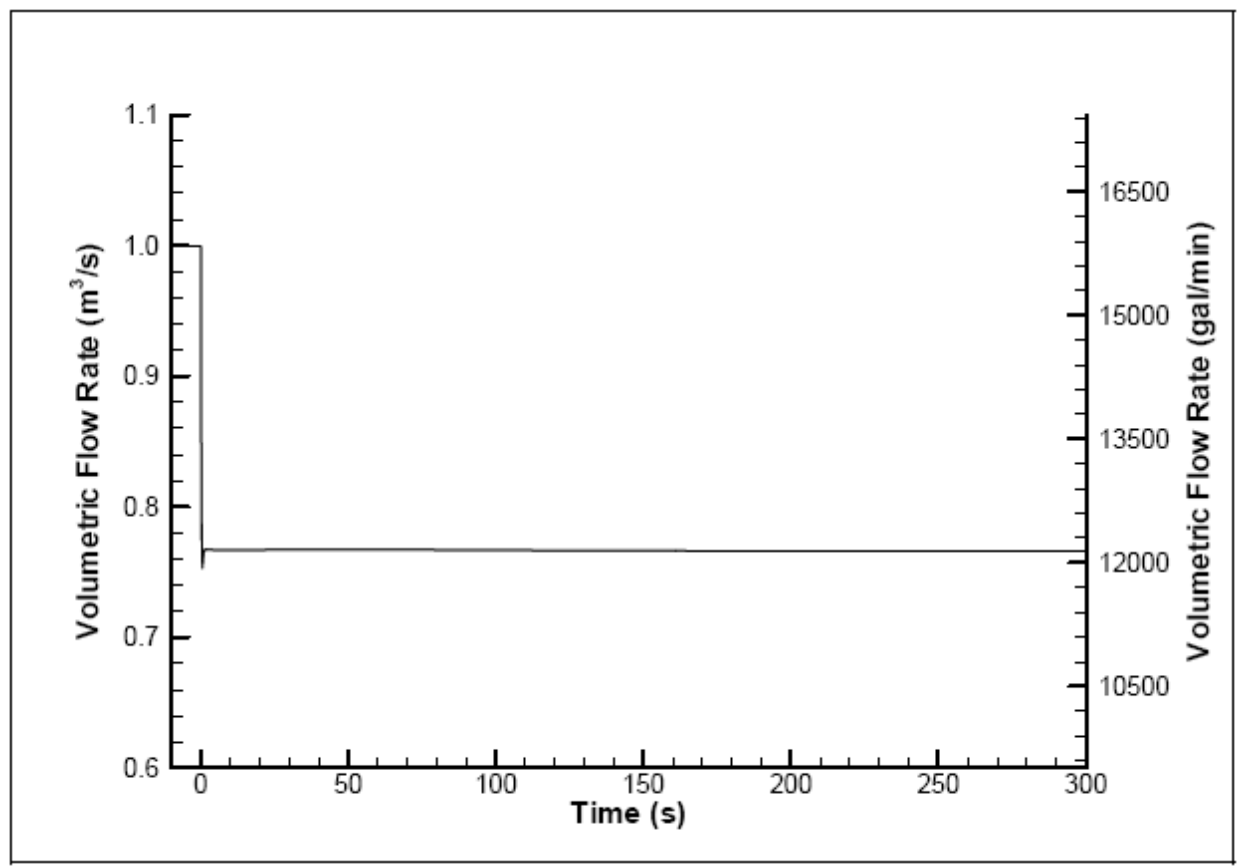

Fig. 4.2. Volumetric flow rate for this transient as found in the most recent version of the USAR of the HFIR. Both initial and final values of the flow are equivalent to the ones shown in the previous graph, only expressed in different parameters. 


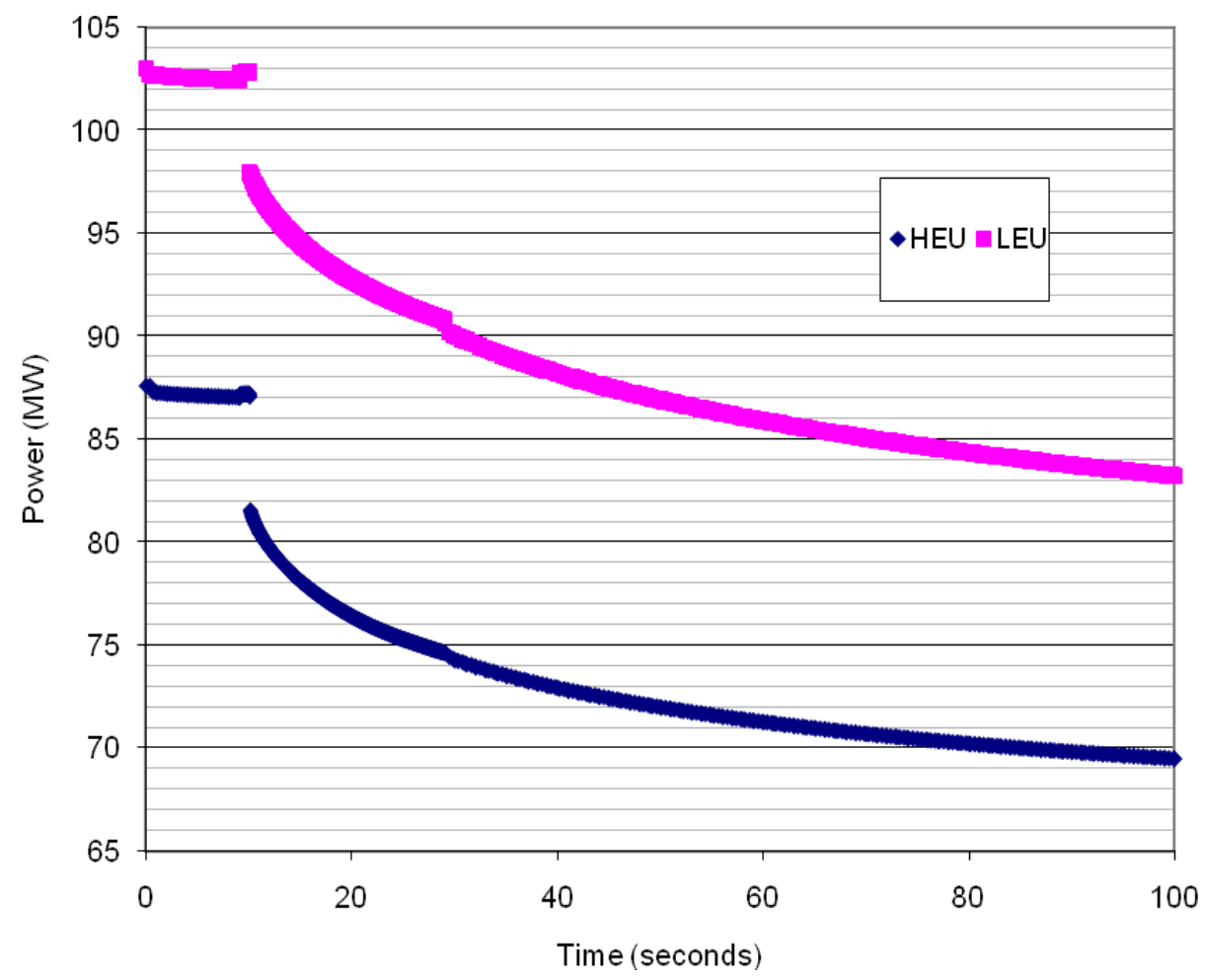

Fig. 4.3. Power profile for primary pump seizure at beginning-of-life.

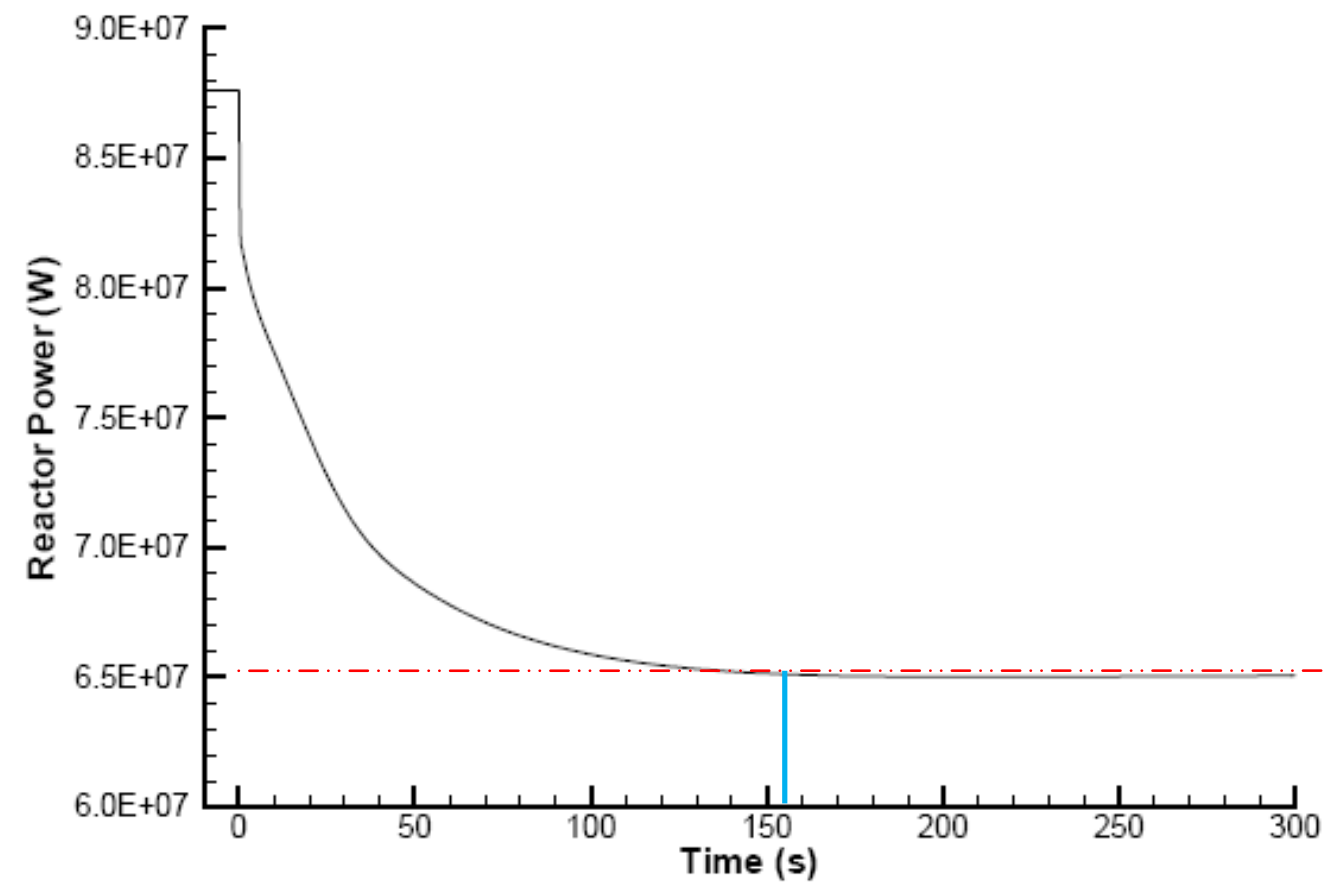

Fig. 4.4. Power profile for HEU transient as found in the USAR. 
The post transient power level at 100 seconds from the current calculation is approximately $5 \%$ greater than the value reported in the HFIR safety analysis report. The feature of consequence, though, is that the time dependence of the transient for LEU fuel is very similar to that of HEU fuel but with slightly less percentage reduction in power from the pre-transient reactor condition.

Fig. 4.5 shows the reactivity change due to the transient as a function of time (data plotted are for the hot channel in the HEU and LEU cases, respectfully). Though small, the reactivity change due to the transient is greater for the HEU fuel than for the LEU fuel. The phenomenon is consistent with the percentage decrease in power for the HEU fuel being slightly greater than that for the LEU fuel.

During initial calculations, two anomalies were visible in the results shown in Fig. 4.5. During the time frame of 0-10 seconds, the PARET code was calculating some small, but negative, reactivity input, perhaps indicating inconsistencies among input parameters. Second, at the point at which the time step is changed from 1 millisecond to 0.1 millisecond, there was a slight increase in negative reactivity. During the course of this work, both anomalies were corrected and a new version of PARET (7.4) was issued by A. Olson of Argonne National Laboratory. Fig. 4.5 was generated with version 7.4 of PARET.

Fig. 4.6 provides temperature profile as a function of time for several locations in the core. Note that the peak temperature in the fuel is $396 \mathrm{~K}$. Figure 4.7 from the HFIR Safety Analysis Report shows the peak clad "wall" temperature as being $487 \mathrm{~K}$. The significant disparity between these two values prompted further investigation.

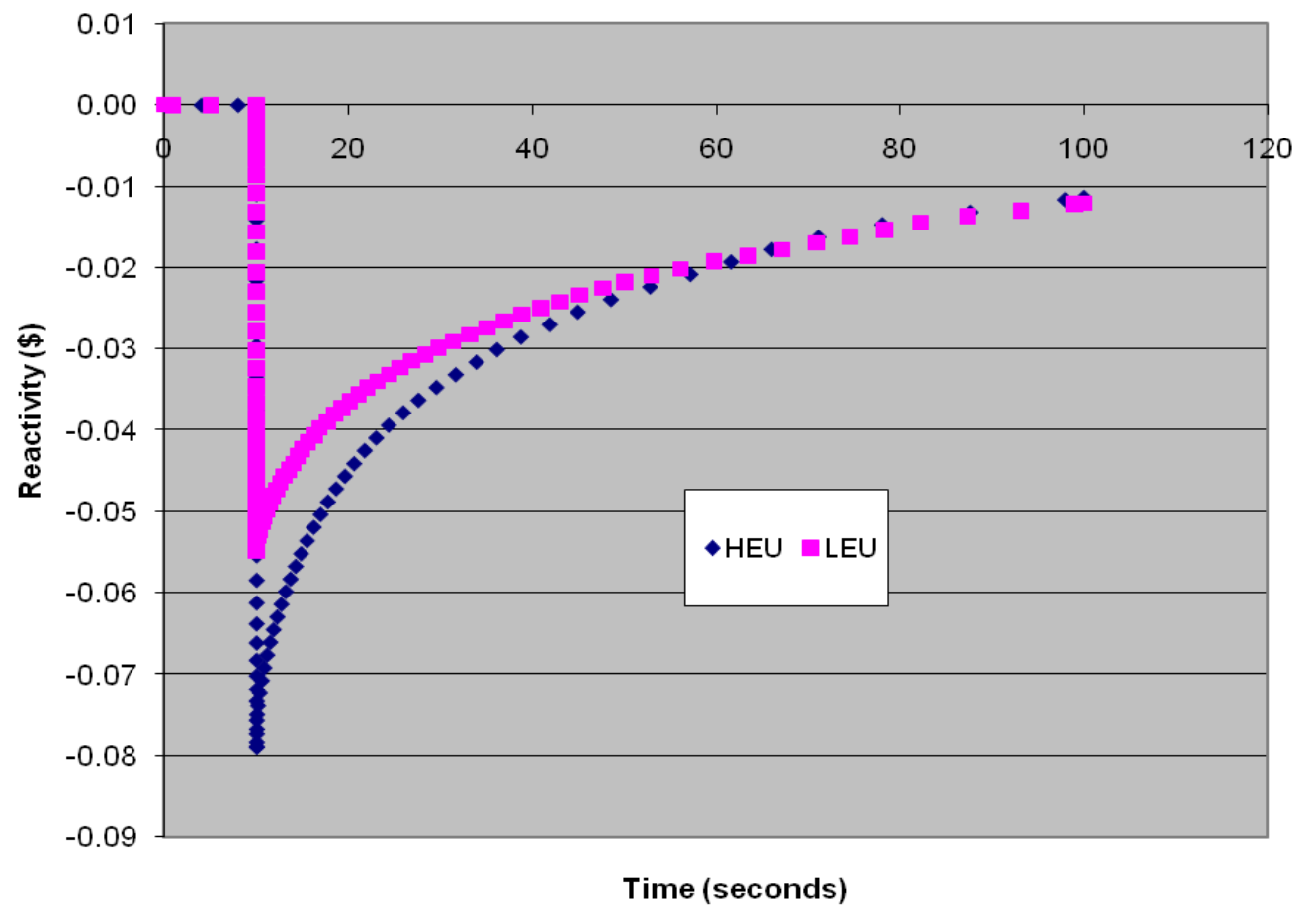

Fig. 4.5. Reactivity profile of the reduction in primary flow transient as calculated with PARET 


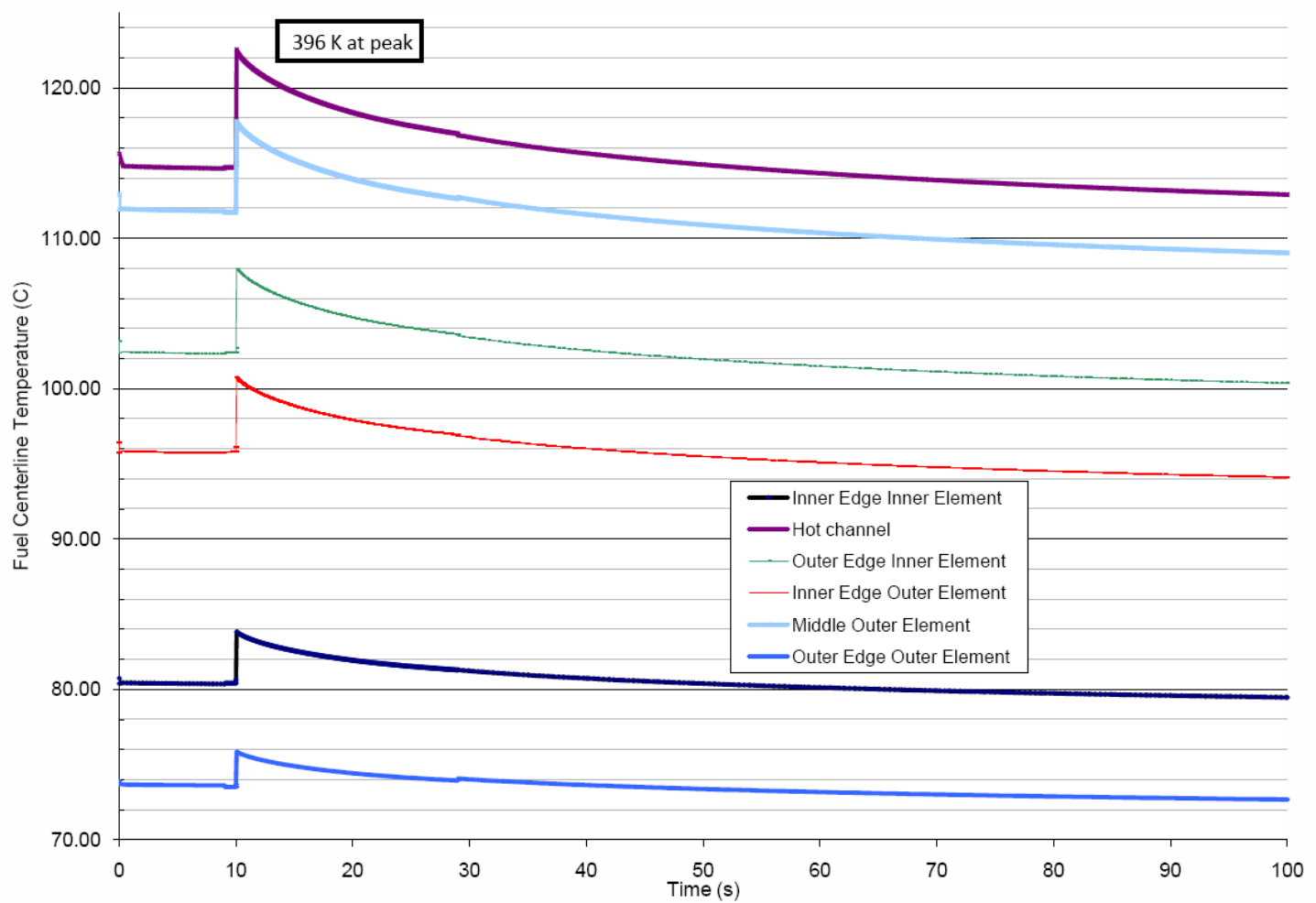

Fig. 4.6. Fuel temperature profile for several core regions for HEU for pump seizure transient.

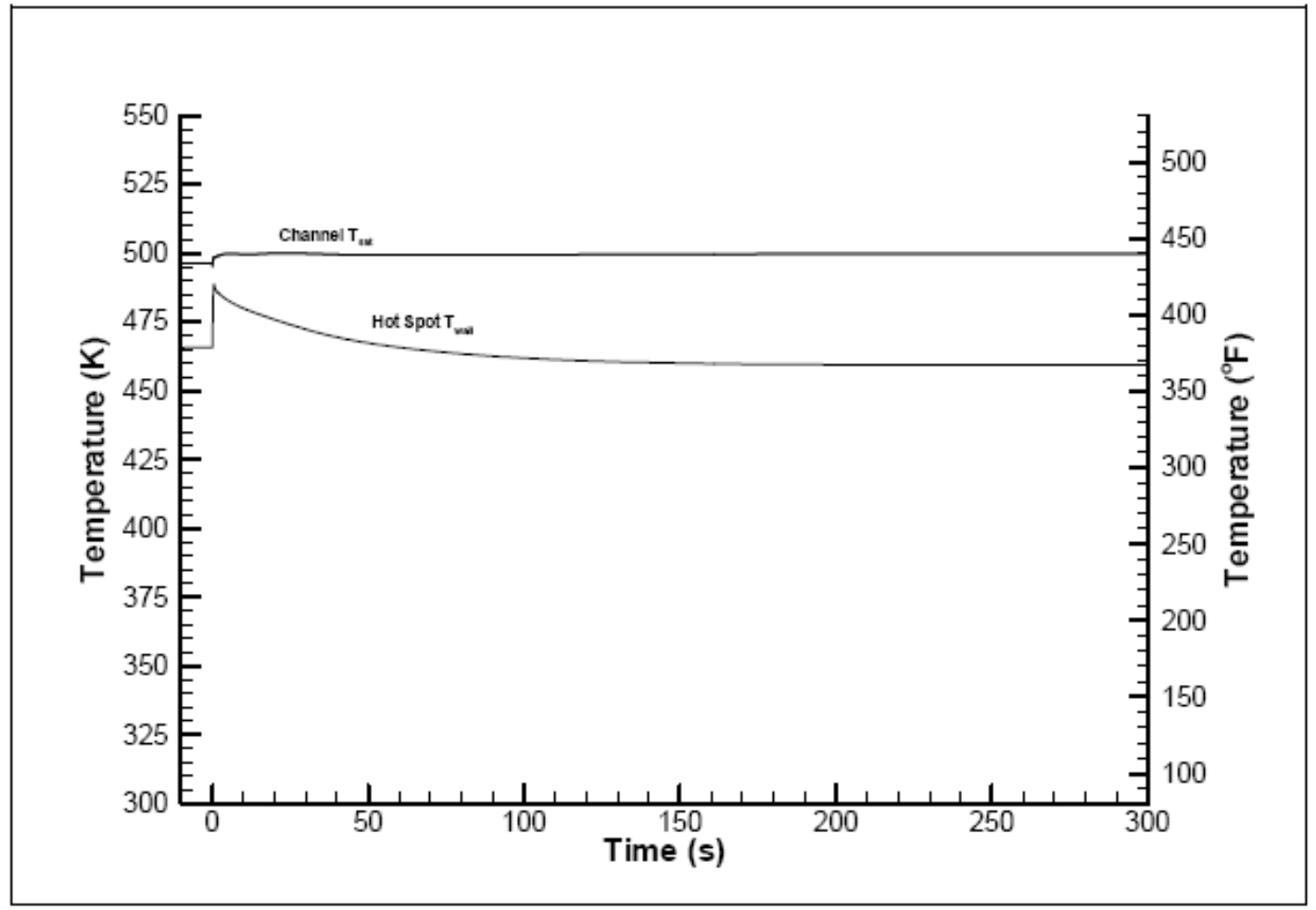

Fig. 4.7. Fuel temperature for transient as reproduced by the USAR. 
Reference 24 provides information as to the assumptions that were the basis of the calculation shown in Fig. 4.7. Whereas the current work is based on the nominal power density from reactor physics calculations, the calculation reported in Fig. 4.7 included the following assumptions not made in the current calculation. The following are assumed to occur simultaneously:

(1) uncertainty in the calculated power distribution (value for a given, calculated, local power density) $-10 \%$

(2) allowance for power tilt associated with experiments loaded to the reactor $-9 \%$,

(3) tolerance on fuel loading in plates accepted from manufacturer - $10 \%$ (current value is $12 \%$ ),

(4) fuel plate length uncertainty $-2.5 \%$,

(5) non-bond of fuel meat to filler or clad $-8 \%$,

(6) maximum allowable peak segregation of $\mathrm{U}_{3} \mathrm{O}_{8}$ from $\mathrm{Al}$ in fuel meat $-27 \%$, and

(7) thermal conductivity of segregated fuel $-13.0 \mathrm{~W} / \mathrm{m}{ }^{\circ} \mathrm{K}$.

In the current, HFIR SAR methodology, these uncertainty values are assumed to be multiplicative and yield a multiplier factor of 1.85 to the local power density at the base of the fuel plate in the hot channel. A more reasonable assumption would be to assume that these individual effects are independent. If so, they can be added in quadratures, reducing the multiplier factor to about 1.13.

The PARET HEU model was modified to include the reduced thermal conductivity of the fuel and the multiplier factor to account for uncertainties. The calculated clad surface temperature at the hot spot was 408 K, $20 \%$ less than the value shown in Fig. 4.7 but certainly in better agreement than before the uncertainties and the SAR thermal conductivity were applied. The fuel hot spot temperature for these conditions was $485 \mathrm{~K}$.

Fuel temperatures at selected locations for LEU fuel in a pump seizure transient without any multiplicative factor are shown in Fig. 4.8. Note that the peak temperature in the LEU fuel is $41 \mathrm{~K}$ higher than for the HEU fuel that is shown in Fig. 4.6.

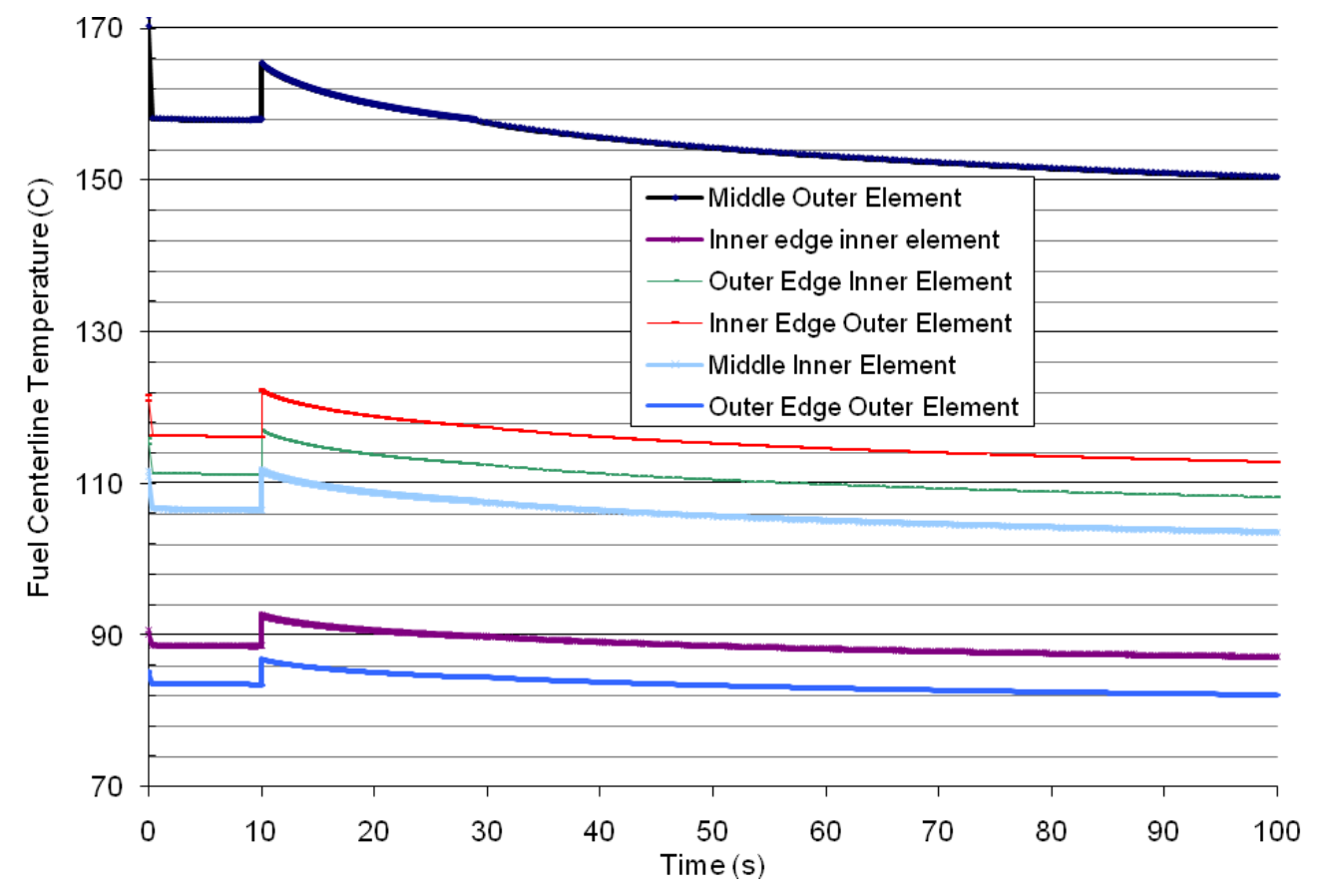

Fig. 4.8. Fuel temperature profile for several core regions for LEU for transient. 
The PARET LEU model was then modified to include the multiplier factor for local power density that accounts for HEU fuel uncertainties. The uncertainty values for LEU/Mo fuel are unknown because no manufacturing experience exists for this fuel. No change was made to the thermal conductivity of the LEU fuel as segregation of the uranium from the molybdenum was not considered credible. The calculated clad surface temperature at the hot spot was $420 \mathrm{~K}$, only $3 \%$ higher than for HEU fuel. The coolant temperature at the hot spot location (exit of hot channel) was $367 \mathrm{~K}(94 \mathrm{C})$. The fuel hot spot temperature for these conditions was $468 \mathrm{~K}$, slightly lower than for HEU. The higher HEU value for hot spot conditions while lower for nominal conditions is due to the higher local power density at the exit of the HEU fuel as compared to the LEU fuel and the hot spot power density for each fuel being the same percentage increase over nominal not the same absolute increase. 


\subsection{CONCLUSIONS}

The reduction in primary coolant flow transient that was analyzed demonstrated that LEU fuel behaves as expected. Under a sudden and large temperature change, the insertion of negative reactivity due to temperature feedback both of the fuel and the coolant causes the LEU fueled core to level off at a lower power than the HEU fuel, which is due to the large self-insertion of negative reactivity caused by the temperature excursion.

Also, based on the tests performed at the high power trip point, it can be observed that the fuel plates of the LEU model reach temperatures higher than those reached by the HEU. While this decreases the margin of safety of the reactor core under this particular transient, the highest temperatures reached $\left(\sim 350{ }^{\circ} \mathrm{C}\right)$ are still acceptable, therefore the safety of the fuel is not compromised.

PARET proved itself to be a code which can be benchmarked easily against problems analyzed with more powerful tools such as RELAP, as Woodruff has demonstrated [4]. In the case of the HFIR, PARET shows an acceptable degree of agreement, but not in all cases. The computational model of the HFIR employed in PARET evolved many times, for instance, by implementing the variable fuel thickness in each of the 17 core regions in order to better represent the actual conditions and maintain flat plate geometry, instead of using half rectangle geometry. On the other hand, PARET can still be further developed. The first author of this report concludes that the restriction to 21 axial mesh segments is not enough to accommodate for large temperature gradients. Also, PARET can still be developed further to accommodate for the curved plates used at the HFIR. To this point, PARET still assumes the use of a flat plate, even while using the half rectangle geometry, which does not reflect the actual conditions.

Another way PARET can still be improved is by further developing the data collection procedures. The code uses a subroutine called POSTPROS which collects the data used in runs and stores them in text files. This subroutine works almost perfectly when the model of the core uses 4 or less core regions. In the case of the HFIR, where 17 core regions were used, this subroutine collects the data in a very cumbersome and impractical way. This is due to the old limitation of 72 characters per line that can be written, a limitation which is no longer present. Another way this data gathering subroutine can be improved is by specifying the interval where certain data points can be skipped by pointing at the time during the transient where this may take place, instead of specifying this by the time step number. In severe transients such as those studied here, small time steps can generate billions of time steps. In such a case, it is impractical to keep track of the time step number where the subroutine can skip certain data points in any given interval of time. Newer (unreleased) versions of PARET have improved filtering of individual channel output data. After the desired time is achieved, these data files are examined for relative change from time point to time point. A time point where the data change is too small compared to the previous saved time point data is filtered out automatically. These files are written as text, to enable their direct use in spread sheet and plotting programs. 
This page blank. 


\subsection{REFERENCES}

1. R. T. Primm III, R. J. Ellis, J. C. Gehin, K. T. Clarno, K. A. Williams, D. L. Moses, Design Study for a Low-Enriched Uranium Core for the High Flux Isotope Reactor, Annual Report for FY 2006, ORNL/TM-2006/136, November 2006.

2. HFIR Updated Safety Analysis Report, ORNL/HFIR/USAR/2344, Rev. 5, Oak Ridge National Laboratory, Oak Ridge, Tennessee, May 2005.

3. Research Reactor Core Conversion from the Use of Highly Enriched Uranium to the Use of Low Enriched Uranium Fuels Guidebook, IAEA-TECDOC-233, Prepared by a consultants group, Coordinated and Edited by the Physics Section, IAEA, Vienna (1980)

4. W. L. Woodruff, N. A. Hanan, R. S. Smith and J. E. Matos. A Comparison of the PARET/ANL and RELAP5/MOD3 Codes for the Analysis of the IAEA Benchmark Transients. ANL/RERTR, 1996 International Meeting on Reduced Enrichment for Research and Test Reactors, October 1996

5. "RELAP5/MOD3 Code Manual, Volume 1: Code Structure, System Models, and Solution Methods," NUREG/CR-5335, INEL-95/0174, Idaho National Engineering Laboratory (June 1995).

6. T. H. Newton, Development of a Low Enriched Uranium Core for the MIT Reactor, Massachusetts Institute of Technology Department of Nuclear Engineering Doctoral Thesis. February 2006.

7. Research Reactor Core Conversion from the Use of Highly Enriched Uranium to the Use of Low Enriched Uranium Fuels Guidebook, IAEA-TECDOC-233, Prepared by a consultants group, Coordinated and Edited by the Physics Section, IAEA, Vienna (1980).

8. C. F. Obenchain, PARET - A Program for the Analysis of Reactor Transients, Phillips Petroleum Company, US Atomic Energy Commission - Idaho Operations Office, IDO-17282, January 1969.

9. A. P. Olson, A Users Guide to the PARET/ANL V7.2 Code - Draft, Reduced Enrichment for Research and Test Reactor (RERTR) Program, Argonne National Lab, Argonne, IL, June 2006.

10. R. T. Primm III and R. J. Ellis, Analysis of an LEU Fuel with Spatially-dependent Thickness in Two Dimensions, Transactions of the 2007 Joint International Topical Meeting on Research Reactor Fuel Management and International Group on Research Reactors, Lyon, France, March 2007.

11. W. L. Woodruff, N. A. Hanan and J. E. Matos, A Comparison of the RELAP5/MOD3 and PARET/ANL Codes with the Experimental Transient Data from the SPERT-IV D-12/25 Series, www.rertr.anl.gov/Analysis97/WWpaper97.pdf

12. Arne P. Olson and S.A. Jonah, MNSR Transient Analyses and Thermal-hydraulic Safety Margins for HEU and LEU Cores Using PARET, Proceedings of the 2007 Meeting of the Reduced Enrichment for Research and Test Reactors Program, 
http://www.rertr.anl.gov/RERTR29/Abstracts/S16-2_Olson.html, Prague, Czech Republic, Sep. 23-27, 2007.

13. M. M. Bretscher and J. L. Snelgrove, The Whole-core LEU $U_{3} S i_{2}$-Al Fuel Demonstration in the 30-MW Oak Ridge Research Reactor, ANL/RERTR/TM-14, July 1991, www.rertr.anl.gov/LEUCONVS/ORR-TM/Chapter1-6.pdf

14. I. H. Bokhari, M. Israr, and S. Pervez, Thermal Hydraulic and Safety Analyses for Pakistan Research Reactor-1, Transactions of the 22nd International Meeting on Reduced Enrichment for Research and Test Reactors (RERTR), Budapest, Hungary,October 4-8, 1999, www.rertr.anl.gov/Web1999/Abstracts/38bokharia99.html

15. J. E. Matos, S.C. Mo. and W.L. Woodruff, Analyses for Conversion of the Georgia Tech Research Reactor from HEU to LEU Fuel, September 1992, www.rertr.anl.gov/LEUCONVS/GTRRSAR.pdf

16. N. A. Hanan, S. C. Mo, and J. E. Matos, Transient Analyses for HEU and LEU Designs of the FRM-II, Presented at the 1998 International Meetingon Reduced Enrichment for Research and Test Reactors, São Paulo, Brazil, October 18 - 23, 1998, www.rertr.anl.gov/Analysis98/NHanan1.pdf

17. R. S. Smith and N. A. Hanan, Analysis of the Effect of Transverse Power Distribution in an Involute Fuel Plate with and without Oxide Film Formation, The 1998 International Meeting Reduced Enrichment for Research and Test Reactor São Paulo, Brazil October 18-23, 1998.

18. C. O. Slater and R. T. Primm, III, Calculation of Rabbit and Simulator Worth in the HFIR Hydraulic Tube and Comparison with Measured Values, ORNL/TM-2005/94, September 2005.

19. R. D. Cheverton, T. M. Sims HFIR Core Nuclear Design, ORNL-4621 UC-80 - Reactor Technology, July 1971.

20. R. T. Primm III, R. J. Ellis, J. C. Gehin, D.L. Moses, J. L. Binder, and N. Xoubi, Assumptions and Criteria for Performing a Feasibility Study of the Conversion of the High Flux Isotope Reactor Core to Use Low-Enriched Uranium Fuel, ORNL/TM-2005/269, February 2006.

21. Thermophysical Properties of Materials for Water Cooled Reactors, IAEA-TECDOC-949. June 1997.

22. MCNP calculation documented in R. T. Primm, III and R. J. Ellis, Analysis of an LEU Fuel with Spatially-dependent Thickness in Two Dimensions, Transactions of the Research Reactor Fuel Management Meeting, RRFM 2007, Lyon, France, March 11-15, 2007.

23. E. B. Wylie and V. C. Streeter, Fluid Transients in Systems, Prentice Hall, Upper Saddle River, NJ. 1993.

24. D. G. Morris, M. W. Wendel. High Flux Isotope Reactor System RELAP5 Input Model, ORNL/TM-11647 February 1993.

25. J. Rest, Y. S. Kim, G. L. Hofman, M. K. Meyer ${ }^{1}$, S. L. Hayes ${ }^{1}$. U-Mo Fuels Handbook, 
Argonne National Lab ( ${ }^{1}$ Idaho National Lab) RERTR Program, June 2006.

26. RRD Procedure SBP-1100, Procedure for Determining the Beginning of Cycle ESCCEP of HFIR Control Plates, (current version).

27. K. A. Smith, HFIR SAR 15.3.3 Decrease in Primary Flow, ORNL/HFIR/USAR/2344/Rev. 6 Approved August, 2006.

28. K. A. Smith, HFIR SAR 15.3.4 Reactivity Transients, ORNL/HFIR/USAR/2344/Rev. 6 Approved August, 2006.

29. A. P. Olson, The PLTEMP V2.1 Code, Proceedings of the 25th International Meeting on Reduced Enrichment for Research and Test Reactors (RERTR), Chicago, Illinois, October 5$10,2003$.

30. H. A. McLain, HFIR Fuel Element Steady State Heat Transfer Analysis, Revised Version, ORNL/TM-1904, Oak Ridge National Laboratory, Oak Ridge, Tennessee, December 1967 as appended by T. E. Cole, L. F. Parsly, and W. E. Thomas, Revisions to the HFIR Steady State Heat Transfer Analysis Code, ORNL/CF-85/68, April 7, 1986.

31. N. Xoubi and R. T. Primm III, Modeling of the High Flux Isotope Reactor Cycle 400, ORNL/TM-2004/251, Oak Ridge National Laboratory, Oak Ridge, Tennessee, August 2005.

32. W. Haeck, and B. Verboomen, An optimum approach to Monte Carlo burnup, Nuclear Science and Engineering, v. 156, pp.180-196, 2007. 
This page blank. 


\section{APPENDIX A}

\section{CALCULATION OF DELAYED NEUTRON PARAMETERS FOR THE HIGH FLUX ISOTOPE REACTOR}

Delayed neutron parameters were computed for the High-Flux Isotope Reactor (HFIR) to support the LEU feasibility study. Parameters specified in the Safety Analysis Report (SAR) [A.1] are available for the HEU core and are used for both the conversion of reactivity values from absolute units to relative (dollar) units and for the safety analysis using the effective delayed neutron fractions and decay constants for six precursor groups. The current effective delayed neutron fraction specified in the SAR is 0.0076 , which was adjusted from the original value of $0.0070-0.0071$ [A.2] based on the value of the delayed neutron yield in ENDF/B-V.

The calculations performed for this work used nuclear data from both the ENDF/B-VI.8 and the ENDF/B-VII.0 data files [A.3]. The total fission neutron yield, delayed neutron yield, six precursorgroup decay constants, relative delayed neutron yields, and delayed neutron emission spectra were extracted from the evaluated nuclear data files and processed to obtained data consistent with a 20 energy-group HFIR BOLD VENTURE model [A.4]. Data was extracted for U-235, U-238, Pu-239 and $\mathrm{Pu}-241$, which are the primary fissioning nuclides in HFIR. Detailed data tables for each of these nuclides are shown in Figs. A.1 (ENDF/B-VI.8 data) and A.2 (ENDF/B-VII.0 data). The tables show small changes for the fission neutron yield at high energies for $\mathrm{Pu}-239$, in addition to the delayed neutron yield for U-235. All other values (spectra, and neutron yields for other nuclides) are the same between ENDF/B-VI.8 and ENDF/B-VII.0. These data were processed and formatted into a DLAYXS interface file for use by BOLD VENTURE for calculating effective delayed neutron fractions using the PERTUBAT module [A.5].

Note that one significant change in ENDF/B-VII.0 from that of ENDF/B-VI.8 is that the delayed neutron yield at thermal energies for U-235 was reduced by about $5 \%$ to a value of 0.01585 , which brings it to closer agreement with Keepin's value [A.5]. A comparison of the delayed neutron yield values is shown in Figure A.3. The ENDF/B-VI.8 evaluation held the delayed neutron yield constant at 0.0167 up to $4 \mathrm{MeV}$. The ENDF/B-VII.0 evaluation uses a value of 0.01585 up to $0.0253 \mathrm{eV}$ and then ramps linearly to the ENDF/B-VI.8 value of 0.0167 at $50 \mathrm{keV}$ and has this value up to $4 \mathrm{MeV}$ [A.6]. Thus, the ENDF/B-VII.0 evaluation provides a different value for the U-235 delayed neutron yield at thermal and fast energies, which is consistent with previous measurements of the delay neutron yields [A.7]. The ENDF/B-VII.0 delayed neutron yield is more consistent with the data originally used in the determination of the HFIR effective delayed neutron fraction while the ENDF/B-VI.8 value is identical to that used in ENDF/B-V and is the basis for the value of the effective delayed neutron fraction in the HFIR SAR.

Using the HFIR BOLD VENTURE models of the HEU and LEU (monolithic U-10Mo fuel) cores, effective delayed neutron parameters and the prompt neutron lifetimes were calculated as a function of exposure. The PERTUBAT modules compute the importance-weighted values of these parameters. The BOLD VENTURE models were modified to perform adjoint-flux calculations at each depletion step to be used by the PERTUBAT module. The results of the calculations are provided in Table A.1 and Table A. 2 for the HEU and LEU cases. Note that the effective delayed neutron fractions for the HEU core are consistent with the SAR value (0.0076) for the ENDF/B-VI.8 library and the original HFIR values (0.0071 in Ref. A.2) for the ENDF/B-VII.0 library. For the current work, the ENDF/BVI.8 values are used to be consistent with the SAR safety analysis for the HEU core. 
The prompt neutron lifetimes differ for the values quoted in the SAR and Cheverton and Sims report (33 $\mu$ s in Ref. A. 2 vs $50 \mu$ s in this work). This may require more investigation of the specific conditions that the neutron lifetimes were measured (ranges are given $33-74 \mu \mathrm{s}$ ), which likely do not correspond to the conditions calculated. In addition, different definitions of neutron lifetime are possible and they may not be consistent.

Another item of interest is the contribution of the different fissioning nuclides to the total effective delayed neutron fraction. Table A.3 provides the contributions for both the HEU and LEU cores. This table shows the larger U-238 contribution to the delayed neutron fraction for the LEU core in comparison to the HEU core. In addition, Pu-239 makes a much larger contribution at EOC for the LEU core than for the HEU core.

In addition to the total effective delayed neutron fraction, six group parameters are available for each fissioning nuclide. Given that U-235 fission for both HEU and LEU dominates the delayed neutron yield, it is reasonable to use the parameters for U-235 scaled to the appropriate total effective delayed neutron fraction.

\section{A.1 References}

1. HFIR Updated Safety Analysis Report, ORNL/HFIR/USAR/2344, Rev. 5, Oak Ridge National Laboratory, Oak Ridge, Tennessee, May 2005.

2. R. D. Cheverton and T. M. Sims, HFIR Core Nuclear Design, ORNL-4621, Oak Ridge National Laboratory, Oak Ridge, Tennessee, 1971.

3. Data obtained from National Nuclear Data Center,www.bnl.gov/endf.

4. J. C. Gehin, Reactor Physics Analysis of the ANS Three-Element Core, ORNL/M-4604, August 1995.

5. D. R. Vondy, T. B. Fowler, and G. W. Cunningham III, The Bold Venture Computation System for Nuclear Reactor Core Analysis, Version III, ORNL-5711, Oak Ridge National Laboratory, Oak Ridge, Tennessee, June 1981.

6. M. B. Chadwick, et al., ENDF/B-VII.0: Next Generation Evaluated Nuclear Data Library for Nuclear Science and Technology, Nuclear Data Sheets, 107 (2006) pp. 2931-3060, December 2006.

7. G. R. Keepin, Physics of Nuclear Kinetics, Addison-Wesley, Reading, Mass., 1965. 
Delayed Neutron Data for u235 (endf/b-vi.8)

$\begin{array}{rlc}\text { broad } & \text { group } & \\ \text { grp } & \text { emin (eV) } & \text { emax (eV) } \\ 1 & 2.4790 \mathrm{E}+06 & 2.0000 \mathrm{E}+07 \\ 2 & 1.5000 \mathrm{E}+06 & 2.4790 \mathrm{E}+06 \\ 3 & 8.7500 \mathrm{E}+05 & 1.5000 \mathrm{E}+06 \\ 4 & 8.5000 \mathrm{E}+04 & 8.7500 \mathrm{E}+05 \\ 5 & 2.5800 \mathrm{E}+03 & 8.5000 \mathrm{E}+04 \\ 6 & 9.0000 \mathrm{E}+01 & 2.5800 \mathrm{E}+03 \\ 7 & 2.7500 \mathrm{E}+01 & 9.0000 \mathrm{E}+01 \\ 8 & 9.1000 \mathrm{E}+00 & 2.7500 \mathrm{E}+01 \\ 9 & 2.9700 \mathrm{E}+00 & 9.1000 \mathrm{E}+00 \\ 10 & 1.6800 \mathrm{E}+00 & 2.9700 \mathrm{E}+00 \\ 11 & 9.7500 \mathrm{E}-01 & 1.6800 \mathrm{E}+00 \\ 12 & 6.2500 \mathrm{E}-01 & 9.7500 \mathrm{E}-01 \\ 13 & 3.7500 \mathrm{E}-01 & 6.2500 \mathrm{E}-01 \\ 14 & 2.5000 \mathrm{E}-01 & 3.7500 \mathrm{E}-01 \\ 15 & 1.2500 \mathrm{E}-01 & 2.5000 \mathrm{E}-01 \\ 16 & 4.0000 \mathrm{E}-02 & 1.2500 \mathrm{E}-01 \\ 17 & 7.5000 \mathrm{E}-03 & 4.0000 \mathrm{E}-02 \\ 18 & 2.5000 \mathrm{E}-03 & 7.5000 \mathrm{E}-03 \\ 19 & 1.5000 \mathrm{E}-03 & 2.5000 \mathrm{E}-03 \\ 20 & 1.0000 \mathrm{E}-05 & 1.5000 \mathrm{E}-03\end{array}$

delaye nubar

total

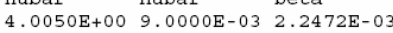
$2.6458 \mathrm{E}+00 \quad 1.6700 \mathrm{E}-02 \quad 6.3120 \mathrm{E}-03$ $2.5517 \mathrm{E}+00 \quad 1.6700 \mathrm{E}-02 \quad 6.5446 \mathrm{E}-03$ $2.4789 \mathrm{E}+00 \quad 1.6700 \mathrm{E}-02 \quad 6.7369 \mathrm{E}-03$ $6.426 \mathrm{E}+001.6700 \mathrm{E}-026.8933 \mathrm{E}-03$ 2.4226E $001.6700 \mathrm{E}-026.893 \mathrm{E}-03$ 2.4338 $0001.6700 \mathrm{E}-026.8617 \mathrm{E}-03$ $2.4338 \mathrm{E}+001.6700 \mathrm{E}-026.6617 \mathrm{E}-03$ $2.4338+001.6700 \mathrm{E}-02-6.8617 \mathrm{E}-03$ $2.4338+001.6700 \mathrm{E}-026.8617 \mathrm{E}-03$ $2.4338 \mathrm{E}+001.6700 \mathrm{E}-026.8617 \mathrm{E}-03$ $2.4358 \mathrm{E}+001.6700 \mathrm{E}-026.8562 \mathrm{E}-03$ $2.4367 \mathrm{E}+001.6700 \mathrm{E}-026.8535 \mathrm{E}-03$ $2.4367 \mathrm{E}+001.6700 \mathrm{E}-026.8535 \mathrm{E}-03$ $2.4367 \mathrm{E}+001.6700 \mathrm{E}-026.8535 \mathrm{E}-03$ $2.4367 \mathrm{E}+001.6700 \mathrm{E}-026.8535 \mathrm{E}-03$ $2.4367 \mathrm{E}+00 \quad 1.6700 \mathrm{E}-02 \quad 6.8535 \mathrm{E}-03$ $2.4367 \mathrm{E}+00 \quad 1.6700 \mathrm{E}-02 \quad 6.8535 \mathrm{E}-03$ $2.4367 \mathrm{E}+00 \quad 1.6700 \mathrm{E}-02 \quad 6.8535 \mathrm{E}-03$ $2.4367 \mathrm{E}+00 \quad 1.6700 \mathrm{E}-02 \quad 6.8535 \mathrm{E}-03$ $2.4367 \mathrm{E}+00 \quad 1.6700 \mathrm{E}-02 \quad 6.8535 \mathrm{E}-03$

mean energy (ev) relative yield decay constant

Delayed Neutron Data for u238 (endf/b-vi.8)

$\begin{array}{rll}\text { broad } & \text { group } & \\ \text { grp } & \text { emin(eV) } & \text { emax (eV) } \\ 1 & 2.4790 \mathrm{E}+06 & 2.0000 \mathrm{E}+07 \\ 2 & 1.5000 \mathrm{E}+06 & 2.4790 \mathrm{E}+06 \\ 3 & 8.7500 \mathrm{E}+05 & 1.5000 \mathrm{E}+06 \\ 4 & 8.5000 \mathrm{E}+04 & 8.7500 \mathrm{E}+05 \\ 5 & 2.5800 \mathrm{E}+03 & 8.5000 \mathrm{E}+04 \\ 6 & 9.0000 \mathrm{E}+01 & 2.5800 \mathrm{E}+03 \\ 7 & 2.7500 \mathrm{E}+01 & 9.0000 \mathrm{E}+01 \\ 8 & 9.1000 \mathrm{E}+00 & 2.7500 \mathrm{E}+01 \\ 9 & 2.9700 \mathrm{E}+00 & 9.1000 \mathrm{E}+00 \\ 10 & 1.6800 \mathrm{E}+00 & 2.9700 \mathrm{E}+00 \\ 11 & 9.7500 \mathrm{E}-01 & 1.6800 \mathrm{E}+00 \\ 12 & 6.2500 \mathrm{E}-01 & 9.7500 \mathrm{E}-01 \\ 13 & 3.7500 \mathrm{E}-01 & 6.2500 \mathrm{E}-01 \\ 14 & 2.5000 \mathrm{E}-01 & 3.7500 \mathrm{E}-01 \\ 15 & 1.2500 \mathrm{E}-01 & 2.5000 \mathrm{E}-01 \\ 16 & 4.0000 \mathrm{E}-02 & 1.2500 \mathrm{E}-01 \\ 17 & 7.5000 \mathrm{E}-03 & 4.0000 \mathrm{E}-02 \\ 18 & 2.5000 \mathrm{E}-03 & 7.5000 \mathrm{E}-03 \\ 19 & 1.5000 \mathrm{E}-03 & 2.5000 \mathrm{E}-03 \\ 20 & 1.0000 \mathrm{E}-05 & 1.5000 \mathrm{E}-03\end{array}$

$\begin{array}{lll}\text { total } & \begin{array}{l}\text { delayed } \\ \text { nubar }\end{array} & \begin{array}{l}\text { total } \\ \text { nubar }\end{array} \\ 4.0357 \mathrm{E}+00 & 2.6000 \mathrm{E}-02 & 6.4425 \mathrm{E}-03 \\ 2.6339 \mathrm{E}+00 & 4.4000 \mathrm{E}-02 & 1.6705 \mathrm{E}-02 \\ 2.5767 \mathrm{E}+00 & 4.4000 \mathrm{E}-02 & 1.7076 \mathrm{E}-02 \\ 2.5263 \mathrm{E}+00 & 4.4000 \mathrm{E}-02 & 1.7417 \mathrm{E}-02 \\ 2.4952 \mathrm{E}+00 & 4.4000 \mathrm{E}-02 & 1.7634 \mathrm{E}-02 \\ 2.4922 \mathrm{E}+00 & 4.4000 \mathrm{E}-02 & 1.7655 \mathrm{E}-02 \\ 2.4921 \mathrm{E}+00 & 4.4000 \mathrm{E}-02 & 1.7656 \mathrm{E}-02 \\ 2.4921 \mathrm{E}+00 & 4.4000 \mathrm{E}-02 & 1.7656 \mathrm{E}-02 \\ 2.4921 \mathrm{E}+00 & 4.4000 \mathrm{E}-02 & 1.7656 \mathrm{E}-02 \\ 2.4921 \mathrm{E}+00 & 4.4000 \mathrm{E}-02 & 1.7656 \mathrm{E}-02 \\ 2.4921 \mathrm{E}+00 & 4.4000 \mathrm{E}-02 & 1.7656 \mathrm{E}-02 \\ 2.4921 \mathrm{E}+00 & 4.4000 \mathrm{E}-02 & 1.7656 \mathrm{E}-02 \\ 2.4921 \mathrm{E}+00 & 4.4000 \mathrm{E}-02 & 1.7656 \mathrm{E}-02 \\ 2.4921 \mathrm{E}+00 & 4.4000 \mathrm{E}-02 & 1.7656 \mathrm{E}-02 \\ 2.4921 \mathrm{E}+00 & 4.4000 \mathrm{E}-02 & 1.7656 \mathrm{E}-02 \\ 2.4921 \mathrm{E}+00 & 4.4000 \mathrm{E}-02 & 1.7656 \mathrm{E}-02 \\ 2.4921 \mathrm{E}+00 & 4.4000 \mathrm{E}-02 & 1.7656 \mathrm{E}-02 \\ 2.4921 \mathrm{E}+00 & 4.4000 \mathrm{E}-02 & 1.7656 \mathrm{E}-02 \\ 2.4921 \mathrm{E}+00 & 4.4000 \mathrm{E}-02 & 1.7656 \mathrm{E}-02 \\ 2.4921 \mathrm{E}+00 & 4.4000 \mathrm{E}-02 & 1.7656 \mathrm{E}-02\end{array}$ sum

mean energy (ev) relative yield
decay constant delayed neutron spectra by delayed group

$\begin{array}{llllll}\text { group 1 } & \text { group 2 } & \text { group 3 } & \text { group 4 } & \text { group 5 } & \text { group 6 }\end{array}$ $\begin{array}{lllllll}2.0000 \mathrm{E}-03 & 3.2670 \mathrm{E}-03 & 1.0529 \mathrm{E}-02 & 3.5309 \mathrm{E}-02 & 3.8507 \mathrm{E}-02 & 4.8507 \mathrm{E}-02\end{array}$ $\begin{array}{lllllll}1.0177 \mathrm{E}-01 & 1.2678 \mathrm{E}-01 & 7.3520 \mathrm{E}-02 & 1.6218 \mathrm{E}-01 & 1.2069 \mathrm{E}-01 & 1.1734 \mathrm{E}-01\end{array}$ $\begin{array}{lllllll}7.5025 \mathrm{E}-01 & 7.7086 \mathrm{E}-01 & 8.2229 \mathrm{E}-01 & 7.2642 \mathrm{E}-01 & 7.4458 \mathrm{E}-01 & 7.1632 \mathrm{E}-01\end{array}$ $\begin{array}{lllllll}1.4474 \mathrm{E}-01 & 9.6349 \mathrm{E}-02 & 9.1538 \mathrm{E}-02 & 7.3115 \mathrm{E}-02 & 9.0706 \mathrm{E}-02 & 1.0778 \mathrm{E}-01\end{array}$

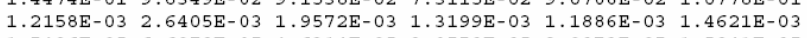
$\begin{array}{lllllll}1.5486 \mathrm{E}-05 & 6.6078 \mathrm{E}-05 & 4.6314 \mathrm{E}-05 & 2.9550 \mathrm{E}-05 & 2.0073 \mathrm{E}-05 & 1.5841 \mathrm{E}-05\end{array}$ $\begin{array}{llllll}1.5486 \mathrm{E}-05 & 6.6078 \mathrm{E}-05 & 4.6314 \mathrm{E}-05 & 2.9550 \mathrm{E}-05 & 2.0073 \mathrm{E}-05 & 1.5841 \mathrm{E}-05 \\ 4.4189 \mathrm{E}-06 & 1.9452 \mathrm{E}-05 & 1.3609 \mathrm{E}-05 & 8.6662 \mathrm{E}-06 & 5.8185 \mathrm{E}-06 & 4.4689 \mathrm{E}-06\end{array}$ $\begin{array}{lllllll}4.4189 \mathrm{E}-06 & 1.9452 \mathrm{E}-05 & 1.3609 \mathrm{E}-05 & 8.6662 \mathrm{E}-06 & 5.8185 \mathrm{E}-06 & 4.4689 \mathrm{E}-06 \\ 1.4580 \mathrm{E}-06 & 6.4801 \mathrm{E}-06 & 4.5311 \mathrm{E}-06 & 2.8838 \mathrm{E}-06 & 1.9292 \mathrm{E}-06 & 1.4692 \mathrm{E}-06\end{array}$ $\begin{array}{lllllll}1.4580 \mathrm{E}-06 & 6.4801 \mathrm{E}-06 & 4.5311 \mathrm{E}-06 & 2.8838 \mathrm{E}-06 & 1.9292 \mathrm{E}-06 & 1.4692 \mathrm{E}-06 \\ 3.0592 \mathrm{E}-07 & 1.3636 \mathrm{E}-06 & 9.5335 \mathrm{E}-07 & 6.0664 \mathrm{E}-07 & 4.0541 \mathrm{E}-07 & 3.0792 \mathrm{E}-07\end{array}$ $\begin{array}{llllll}3.0592 \mathrm{E}-07 & 1.3636 \mathrm{E}-06 & 9.5335 \mathrm{E}-07 & 6.0664 \mathrm{E}-07 & 4.0541 \mathrm{E}-07 & 3.0792 \mathrm{E}-07 \\ 1.6706 \mathrm{E}-07 & 7.4525 \mathrm{E}-07 & 5.2099 \mathrm{E}-07 & 3.3151 \mathrm{E}-07 & 2.2147 \mathrm{E}-07 & 1.6810 \mathrm{E}-07\end{array}$

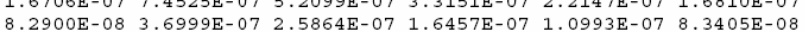
$5.9201 \mathrm{E}-082.6427 \mathrm{E}-07 \quad 1.8474 \mathrm{E}-07 \quad 1.3755 \mathrm{E}-07 \quad 7.8512 \mathrm{E}-08 \quad 5.9555 \mathrm{E}-08$ $2.9597 \mathrm{E}-08 \quad 1.3213 \mathrm{E}-07 \quad 9.2370 \mathrm{E}-08 \quad 5.8773 \mathrm{E}-08 \quad 3.9252 \mathrm{E}-08 \quad 2.9771 \mathrm{E}-08$

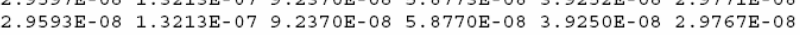
$\begin{array}{llllll}2.0122 \mathrm{E}-08 & 8.9854 \mathrm{E}-08 & 6.2812 \mathrm{E}-08 & 3.9965 \mathrm{E}-08 & 2.6689 \mathrm{E}-08 & 2.0240 \mathrm{E}-08\end{array}$ $\begin{array}{llllll}7.6933 \mathrm{E}-09 & 3.4355 \mathrm{E}-08 & 2.4016 \mathrm{E}-08 & 1.5280 \mathrm{E}-08 & 1.0205 \mathrm{E}-08 & 7.7380 \mathrm{E}-09\end{array}$ $\begin{array}{llllll}1.1835 \mathrm{E}-09 & 5.2855 \mathrm{E}-09 & 3.6948 \mathrm{E}-09 & 2.3508 \mathrm{E}-09 & 1.5699 \mathrm{E}-09 & 1.1905 \mathrm{E}-09\end{array}$ $\begin{array}{llllll}2.3671 \mathrm{E}-10 & 1.0571 \mathrm{E}-09 & 7.3896 \mathrm{E}-10 & 4.7017 \mathrm{E}-10 & 3.1398 \mathrm{E}-10 & 2.3809 \mathrm{E}-10\end{array}$ $\begin{array}{llllll}3.5270 \mathrm{E}-10 & 1.5751 \mathrm{E}-09 & 1.1010 \mathrm{E}-09 & 7.0055 \mathrm{E}-10 & 4.6785 \mathrm{E}-10 & 3.5476 \mathrm{E}-10\end{array}$ $1.0000 \mathrm{E}+001.0000 \mathrm{E}+00 \quad 1.0000 \mathrm{E}+00 \quad 1.0000 \mathrm{E}+00 \quad 1.0000 \mathrm{E}+00 \quad 1.0000 \mathrm{E}+00$

$\begin{array}{lllll}4.0079 \mathrm{E}+05 \quad 4.6901 \mathrm{E}+05 \quad 4.3925 \mathrm{E}+05 \quad 5.5373 \mathrm{E}+05 \quad 5.1401 \mathrm{E}+05 \quad 5.3587 \mathrm{E}+05 & 5\end{array}$ $\begin{array}{lllllll}3.5008 \mathrm{E}-02 & 1.8070 \mathrm{E}-01 & 1.7251 \mathrm{E}-01 & 3.8678 \mathrm{E}-01 & 1.5858 \mathrm{E}-01 & 6.6427 \mathrm{E}-02\end{array}$ $\begin{array}{lllllll}1.3336 \mathrm{E}-02 & 3.2739 \mathrm{E}-02 & 1.2078 \mathrm{E}-01 & 3.0278 \mathrm{E}-01 & 8.4949 \mathrm{E}-01 & 2.8530 \mathrm{E}+00\end{array}$

delayed neutron spectra by delayed group

group 1 group 2 group 3 group 4 group 5 group 6 $\begin{array}{llllll}0.0000 \mathrm{E}+00 & 0.0000 \mathrm{E}+00 & 1.0683 \mathrm{E}-04 & 2.2494 \mathrm{E}-03 & 5.7624 \mathrm{E}-03 & 1.0223 \mathrm{E}-02\end{array}$ $\begin{array}{llllll}2.4237 \mathrm{E}-03 & 3.7636 \mathrm{E}-03 & 9.7684 \mathrm{E}-03 & 3.9085 \mathrm{E}-02 & 3.9468 \mathrm{E}-02 & 5.1699 \mathrm{E}-02\end{array}$ $\begin{array}{llllll}1.2144 \mathrm{E}-01 & 1.4521 \mathrm{E}-01 & 7.2600 \mathrm{E}-02 & 1.6085 \mathrm{E}-01 & 1.1106 \mathrm{E}-01 & 1.2190 \mathrm{E}-01\end{array}$ $7.5290 \mathrm{E}-017.6739 \mathrm{E}-018.1765 \mathrm{E}-01 \mathrm{~T} .1788 \mathrm{E}-01 \mathrm{~T} 7.4555 \mathrm{E}-01 \mathrm{7.137}$ $\begin{array}{llllll}1.2222 \mathrm{E}-01 & 8.1389 \mathrm{E}-02 & 9.7568 \mathrm{E}-02 & 7.8163 \mathrm{E}-02 & 9.6863 \mathrm{E}-02 & 1.0132 \mathrm{E}-01\end{array}$ $\begin{array}{llllll}9.9841 \mathrm{E}-04 & 2.1617 \mathrm{E}-03 & 2.2262 \mathrm{E}-03 & 1.7166 \mathrm{E}-03 & 1.2631 \mathrm{E}-03 & 1.1290 \mathrm{E}-03\end{array}$ $\begin{array}{llllll}1.2707 \mathrm{E}-05 & 5.4550 \mathrm{E}-05 & 5.3003 \mathrm{E}-05 & 4.0074 \mathrm{E}-05 & 2.3760 \mathrm{E}-05 & 1.4931 \mathrm{E}-05\end{array}$ 3.6257E-06 1.6062E-05 1.5577E-05 1.1770E-05 6.9209E-06 $4.2705 \mathrm{E}-06$ 1.1963E-06 5.3515E-06 $5.1869 \mathrm{E}-06 \quad 3.9183 \mathrm{E}-06 \quad 2.2982 \mathrm{E}-06 \quad 1.4101 \mathrm{E}-06$ 2.5100E-07 1.1262E-06 $1.0914 \mathrm{E}-06 \quad 8.2439 \mathrm{E}-07 \quad 4.8316 \mathrm{E}-07 \quad 2.9593 \mathrm{E}-07$ $\begin{array}{llllll}1.3707 \mathrm{E}-07 & 6.1547 \mathrm{E}-07 & 5.9640 \mathrm{E}-07 & 4.5051 \mathrm{E}-07 & 2.6398 \mathrm{E}-07 & 1.6161 \mathrm{E}-07\end{array}$ $\begin{array}{llllll}6.8018 \mathrm{E}-08 & 3.0555 \mathrm{E}-07 & 2.9609 \mathrm{E}-07 & 2.2365 \mathrm{E}-07 & 1.3104 \mathrm{E}-07 & 8.0202 \mathrm{E}-08\end{array}$ $\begin{array}{llllll}4.8572 \mathrm{E}-08 & 2.1825 \mathrm{E}-07 & 2.1149 \mathrm{E}-07 & 1.5975 \mathrm{E}-07 & 9.3592 \mathrm{E}-08 & 5.7275 \mathrm{E}-08\end{array}$

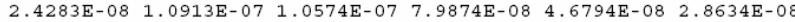
$\begin{array}{llllll}2.4280 \mathrm{E}-08 & 1.0913 \mathrm{E}-07 & 1.0574 \mathrm{E}-07 & 7.9870 \mathrm{E}-08 & 4.6791 \mathrm{E}-08 & 2.8631 \mathrm{E}-08\end{array}$ $\begin{array}{llllll}1.6509 \mathrm{E}-08 & 7.4208 \mathrm{E}-08 & 7.1905 \mathrm{E}-08 & 5.4314 \mathrm{E}-08 & 3.1818 \mathrm{E}-08 & 1.9468 \mathrm{E}-08\end{array}$ $\begin{array}{llllll}6.3121 E-09 & 2.8373 \mathrm{E}-08 & 2.7493 \mathrm{E}-08 & 2.0766 \mathrm{E}-08 & 1.2165 \mathrm{E}-08 & 7.4430 \mathrm{E}-09\end{array}$ $9.7109 \mathrm{E}-10 \quad 4.3651 \mathrm{E}-09 \quad 4.2296 \mathrm{E}-09 \quad 3.1948 \mathrm{E}-09 \quad 1.8716 \mathrm{E}-09 \quad 1.1451 \mathrm{E}-09$ $\begin{array}{llllll}1.9421 \mathrm{E}-10 & 8.7299 \mathrm{E}-10 & 8.4591 \mathrm{E}-10 & 6.3897 \mathrm{E}-10 & 3.7431 \mathrm{E}-10 & 2.2901 \mathrm{E}-10\end{array}$

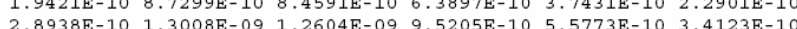
$1.0000 \mathrm{E}+00 \quad 1.0000 \mathrm{E}+00 \quad 1.0000 \mathrm{E}+00 \quad 1.0000 \mathrm{E}+00 \quad 1.0000 \mathrm{E}+00 \quad 1.0000 \mathrm{E}+00$

$4.4090 \mathrm{E}+05 \quad 5.0662 \mathrm{E}+05 \quad 4.2594 \mathrm{E}+05 \quad 5.5192 \mathrm{E}+05 \quad 5.0645 \mathrm{E}+05 \quad 5.4802 \mathrm{E}+05$ $\begin{array}{llllll}1.3938 \mathrm{E}-02 & 1.1280 \mathrm{E}-01 & 1.3103 \mathrm{E}-01 & 3.8514 \mathrm{E}-01 & 2.5399 \mathrm{E}-01 & 1.0310 \mathrm{E}-01\end{array}$

$\begin{array}{lllllll}1.3630 \mathrm{E}-02 & 3.1334 \mathrm{E}-02 & 1.2334 \mathrm{E}-01 & 3.2373 \mathrm{E}-01 & 9.0597 \mathrm{E}-01 & 3.0487 \mathrm{E}+00\end{array}$
Delayed Neutron Data for pu239 (endf/b-vi.8)

\begin{tabular}{rlc} 
broad & \multicolumn{2}{l}{ group } \\
grp & emin $(\mathrm{eV})$ & emax $(\mathrm{eV})$ \\
1 & $2.4790 \mathrm{E}+06$ & $2.0000 \mathrm{E}+07$ \\
2 & $1.5000 \mathrm{E}+06$ & $2.4790 \mathrm{E}+06$ \\
3 & $8.7500 \mathrm{E}+05$ & $1.5000 \mathrm{E}+06$ \\
4 & $8.5000 \mathrm{E}+04$ & $8.7500 \mathrm{E}+05$ \\
5 & $2.5800 \mathrm{E}+03$ & $8.5000 \mathrm{E}+04$ \\
6 & $9.0000 \mathrm{E}+01$ & $2.5800 \mathrm{E}+03$ \\
7 & $2.7500 \mathrm{E}+01$ & $9.0000 \mathrm{E}+01$ \\
8 & $9.1000 \mathrm{E}+00$ & $2.7500 \mathrm{E}+01$ \\
9 & $2.9700 \mathrm{E}+00$ & $9.1000 \mathrm{E}+00$ \\
10 & $1.6800 \mathrm{E}+00$ & $2.9700 \mathrm{E}+00$ \\
11 & $9.7500 \mathrm{E}-01$ & $1.6800 \mathrm{E}+00$ \\
12 & $6.2500 \mathrm{E}-01$ & $9.7500 \mathrm{E}-01$ \\
13 & $3.7500 \mathrm{E}-01$ & $6.2500 \mathrm{E}-01$ \\
14 & $2.5000 \mathrm{E}-01$ & $3.7500 \mathrm{E}-01$ \\
15 & $1.2500 \mathrm{E}-01$ & $2.5000 \mathrm{E}-01$ \\
16 & $4.0000 \mathrm{E}-02$ & $1.2500 \mathrm{E}-01$ \\
17 & $7.5000 \mathrm{E}-03$ & $4.0000 \mathrm{E}-02$ \\
18 & $2.5000 \mathrm{E}-03$ & $7.5000 \mathrm{E}-03$ \\
19 & $1.5000 \mathrm{E}-03$ & $2.5000 \mathrm{E}-03$ \\
20 & $1.0000 \mathrm{E}-05$ & $1.5000 \mathrm{E}-03$
\end{tabular}

nubar delay

total

$\begin{array}{lll}4.5634 \mathrm{E}+00 & 4.3000 \mathrm{E}-03 & 9.4227 \mathrm{E}-04\end{array}$ $3.1752 \mathrm{E}+00 \quad 6.4500 \mathrm{E}-03 \quad 2.0314 \mathrm{E}-03$ $3.0451 \mathrm{E}+00 \quad 6.4500 \mathrm{E}-03 \quad 2.1182 \mathrm{E}-03$ $2.9453 \mathrm{E}+00 \quad 6.4500 \mathrm{E}-03 \quad 2.1899 \mathrm{E}-03$ $2.8983 \mathrm{E}+00 \quad 6.4500 \mathrm{E}-03 \quad 2.2254 \mathrm{E}-03$ $2.8943 \mathrm{E}+00 \quad 6.4500 \mathrm{E}-03 \quad 2.2285 \mathrm{E}-03$ $2.8872 \mathrm{E}+00 \quad 6.4500 \mathrm{E}-03 \quad 2.2340 \mathrm{E}-03$ $2.8632 \mathrm{E}+00 \quad 6.4500 \mathrm{E}-03 \quad 2.2527 \mathrm{E}-03$ . $.8704 \mathrm{E}+000.4500 \mathrm{E}-032.2527 \mathrm{E}-03$

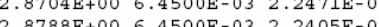
\begin{tabular}{lll}
$2.8788 \mathrm{E}+00$ & $6.4500 \mathrm{E}-03$ & $2.2405 \mathrm{E}-0$ \\
\hline
\end{tabular} .

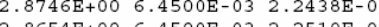
. . $2.8739 \mathrm{E}+00 \quad 6.4500 \mathrm{E}-03 \quad 2.2443 \mathrm{E}-0$ $2.8790 \mathrm{E}+00 \quad 6.4500 \mathrm{E}-03 \quad 2.2404 \mathrm{E}-0$ $2.8804 \mathrm{E}+00 \quad 6.4500 \mathrm{E}-03 \quad 2.2393 \mathrm{E}-0$ $2.8806 \mathrm{E}+00 \quad 6.4500 \mathrm{E}-03 \quad 2.2391 \mathrm{E}-03$ $\begin{array}{lll}2.8807 \mathrm{E}+00 & 6.4500 \mathrm{E}-03 \quad 2.2391 \mathrm{E}-03\end{array}$

sum delayed neutron spectra by delayed group $\begin{array}{llllll}\text { group } 1 & \text { group 2 } & \text { group } 3 & \text { group 4 } & \text { group } 5 & \text { group 6 } \\ 0.0000 \mathrm{E}+00 & 0.0000 \mathrm{E}+00 & 7.0488 \mathrm{E}-05 & 1.1506 \mathrm{E}-03 & 2.8300 \mathrm{E}-03 & 8.3058 \mathrm{E}-03\end{array}$ $\begin{array}{llllll}2.0952 \mathrm{E}-03 & 3.6845 \mathrm{E}-03 & 8.8427 \mathrm{E}-03 & 2.5403 \mathrm{E}-03 & 2.8300 \mathrm{E}-03 & 8.3058 \mathrm{E}-03\end{array}$ $\begin{array}{llllll}1.0618 \mathrm{E}-01 & 1.5938 \mathrm{E}-01 & 6.7873 \mathrm{E}-02 & 1.3179 \mathrm{E}-01 & 9.5151 \mathrm{E}-02 & 4.4540 \mathrm{E}-02\end{array}$ $\begin{array}{llllll}7.5087 \mathrm{E}-01 & 7.6787 \mathrm{E}-01 & 8.1492 \mathrm{E}-01 & 7.5847 \mathrm{E}-01 & 7.8572 \mathrm{E}-01 & 7.2605 \mathrm{E}-01\end{array}$ $\begin{array}{llllll}1.3967 \mathrm{E}-01 & 6.7388 \mathrm{E}-02 & 1.0558 \mathrm{E}-01 & 8.1804 \mathrm{E}-02 & 8.9309 \mathrm{E}-02 & 1.1546 \mathrm{E}-01\end{array}$ $\begin{array}{llllll}1.1647 \mathrm{E}-03 & 1.6259 \mathrm{E}-03 & 2.6257 \mathrm{E}-03 & 1.2614 \mathrm{E}-03 & 9.6021 \mathrm{E}-04 & 1.6605 \mathrm{E}-03\end{array}$ $\begin{array}{llllll}1.4837 \mathrm{E}-05 & 4.0676 \mathrm{E}-05 & 6.3258 \mathrm{E}-05 & 2.6733 \mathrm{E}-05 & 1.5428 \mathrm{E}-05 & 1.6836 \mathrm{E}-05\end{array}$ $\begin{array}{llllll}4.2335 \mathrm{E}-06 & 1.1974 \mathrm{E}-05 & 1.8599 \mathrm{E}-05 & 7.8243 \mathrm{E}-06 & 4.4611 \mathrm{E}-06 & 4.7246 \mathrm{E}-06\end{array}$ $\begin{array}{llllll}1.3968 \mathrm{E}-06 & 3.9890 \mathrm{E}-06 & 6.1936 \mathrm{E}-06 & 2.6020 \mathrm{E}-06 & 1.4780 \mathrm{E}-06 & 1.5506 \mathrm{E}-06\end{array}$ $2.9309 \mathrm{E}-07 \quad 8.3944 \mathrm{E}-07 \quad 1.3032 \mathrm{E}-06 \quad 5.4727 \mathrm{E}-07 \quad 3.1052 \mathrm{E}-07 \quad 3.2482 \mathrm{E}-07$ $1.6005 \mathrm{E}-07 \quad 4.5877 \mathrm{E}-07 \quad 7.1222 \mathrm{E}-07 \quad 2.9905 \mathrm{E}-07 \quad 1.6963 \mathrm{E}-07 \quad 1.7730 \mathrm{E}-07$ $\begin{array}{lllllll}7.9424 \mathrm{E}-08 & 2.2775 \mathrm{E}-07 & 3.5357 \mathrm{E}-07 & 1.4845 \mathrm{E}-07 & 8.4193 \mathrm{E}-08 & 8.7962 \mathrm{E}-08\end{array}$ $\begin{array}{llllll}5.6718 \mathrm{E}-08 & 1.6268 \mathrm{E}-07 & 2.5255 \mathrm{E}-07 & 1.0603 \mathrm{E}-07 & 6.0129 \mathrm{E}-08 & 6.2806 \mathrm{E}-08\end{array}$ $2.8354 \mathrm{E}-08 \quad 8.1342 \mathrm{E}-08 \quad 1.2628 \mathrm{E}-07 \quad 5.3014 \mathrm{E}-08 \quad 3.0062 \mathrm{E}-08 \quad 3.1396 \mathrm{E}-08$

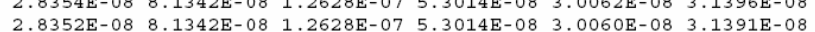
$\begin{array}{llllll}1.9277 \mathrm{E}-08 & 5.5310 \mathrm{E}-08 & 8.5866 \mathrm{E}-08 & 3.6049 \mathrm{E}-08 & 2.0440 \mathrm{E}-08 & 2.1343 \mathrm{E}-08\end{array}$

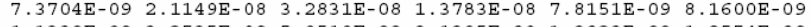
$\begin{array}{llllll}1.1339 \mathrm{E}-09 & 3.2535 \mathrm{E}-09 & 5.0510 \mathrm{E}-09 & 2.1205 \mathrm{E}-09 & 1.2023 \mathrm{E}-09 & 1.2554 \mathrm{E}-09\end{array}$ $\begin{array}{llllll}2.2679 \mathrm{E}-10 & 6.5071 \mathrm{E}-10 & 1.0102 \mathrm{E}-09 & 4.2411 \mathrm{E}-10 & 2.4047 \mathrm{E}-10 & 2.5108 \mathrm{E}-10\end{array}$

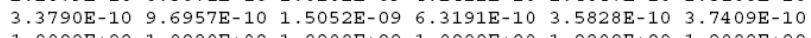

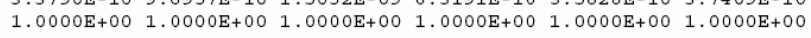

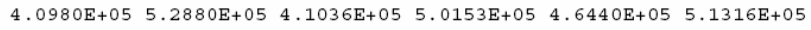
$\begin{array}{lllllll}3.6306 \mathrm{E}-02 & 2.3644 \mathrm{E}-01 & 1.7893 \mathrm{E}-01 & 3.2667 \mathrm{E}-01 & 1.7016 \mathrm{E}-01 & 5.1500 \mathrm{E}-02 \\ 1.3271 \mathrm{E}-02 & 3.0881 \mathrm{E}-02 & 1.1337 \mathrm{E}-01 & 2.9250 \mathrm{E}-01 & 8.5749 \mathrm{E}-01 & 2.7297 \mathrm{E}+00\end{array}$

Fig. A.1. Selected data from ENDF/B-VI.8 library. 
Delayed Neutron Data for pu241 (endf/b-vi.8)

$\begin{array}{rlc}\text { broad } & \text { group } \\ \text { grp } & \text { emin }(\mathrm{eV}) & \text { emax }(\mathrm{eV}) \\ 1 & 2.4790 \mathrm{E}+06 & 2.0000 \mathrm{E}+07 \\ 2 & 1.5000 \mathrm{E}+06 & 2.4790 \mathrm{E}+06 \\ 3 & 8.7500 \mathrm{E}+05 & 1.5000 \mathrm{E}+06 \\ 4 & 8.5000 \mathrm{E}+04 & 8.7500 \mathrm{E}+05 \\ 5 & 2.5800 \mathrm{E}+03 & 8.5000 \mathrm{E}+04 \\ 6 & 9.0000 \mathrm{E}+01 & 2.5800 \mathrm{E}+03 \\ 7 & 2.7500 \mathrm{E}+01 & 9.0000 \mathrm{E}+01 \\ 8 & 9.1000 \mathrm{E}+00 & 2.7500 \mathrm{E}+01 \\ 9 & 2.9700 \mathrm{E}+00 & 9.1000 \mathrm{E}+00 \\ 10 & 1.6800 \mathrm{E}+00 & 2.9700 \mathrm{E}+00 \\ 11 & 9.7500 \mathrm{E}-01 & 1.6800 \mathrm{E}+00 \\ 12 & 6.2500 \mathrm{E}-01 & 9.7500 \mathrm{E}-01 \\ 13 & 3.7500 \mathrm{E}-01 & 6.2500 \mathrm{E}-01 \\ 14 & 2.5000 \mathrm{E}-01 & 3.7500 \mathrm{E}-01 \\ 15 & 1.2500 \mathrm{E}-01 & 2.5000 \mathrm{E}-01 \\ 16 & 4.0000 \mathrm{E}-02 & 1.2500 \mathrm{E}-01 \\ 17 & 7.5000 \mathrm{E}-03 & 4.0000 \mathrm{E}-02 \\ 18 & 2.5000 \mathrm{E}-03 & 7.5000 \mathrm{E}-03 \\ 19 & 1.5000 \mathrm{E}-03 & 2.5000 \mathrm{E}-03 \\ 20 & 1.0000 \mathrm{E}-05 & 1.5000 \mathrm{E}-03\end{array}$

nubar

delaye

nubar

total

beta

$4.6174 \mathrm{E}+00 \quad 8.4000 \mathrm{E}-03 \quad 1.8192 \mathrm{E}-03$ $3.1867 \mathrm{E}+00 \quad 1.6200 \mathrm{E}-02 \quad 5.0837 \mathrm{E}-03$ $3.0591 \mathrm{E}+00 \quad 1.6200 \mathrm{E}-02 \quad 5.2957 \mathrm{E}-03$ $2.9466 \mathrm{E}+00 \quad 1.6200 \mathrm{E}-02 \quad 5.4979 \mathrm{E}-03$ $2.9453 \mathrm{E}+001.6200 \mathrm{E}-025.5003 \mathrm{E}-03$

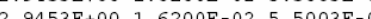
. $.9453 \mathrm{E}+001.6200 \mathrm{E}-025.5003 \mathrm{E}-03$

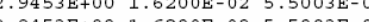
. . $.9453+001.6200 \mathrm{E}-025.5003 \mathrm{E}-03$ . $.9453 \mathrm{E}+001.6200 \mathrm{E}-025.5003 \mathrm{E}-03$ $2.9453 \mathrm{E}+001.6200 \mathrm{E}-02 \quad 5.5003 \mathrm{E}-03$ 2. $9453 \mathrm{E}+001.6200 \mathrm{E}-025.5003 \mathrm{E}-03$ $2.9453 \mathrm{E}+001.6200 \mathrm{E}-025.5003 \mathrm{E}-03$ $2.9453 \mathrm{E}+001.6200 \mathrm{E}-02 \quad 5.5003 \mathrm{E}-0$ $2.9453 \mathrm{E}+001.6200 \mathrm{E}-02 \quad 5.5003 \mathrm{E}-03$ $2.9453 \mathrm{E}+00 \quad 1.6200 \mathrm{E}-02 \quad 5.5003 \mathrm{E}-03$ $2.9453 \mathrm{E}+00 \quad 1.6200 \mathrm{E}-02 \quad 5.5003 \mathrm{E}-03$ $2.9453 \mathrm{E}+00 \quad 1.6200 \mathrm{E}-02 \quad 5.5003 \mathrm{E}-03$ $2.9453 \mathrm{E}+00 \quad 1.6200 \mathrm{E}-02 \quad 5.5003 \mathrm{E}-03$ $2.9453 \mathrm{E}+00 \quad 1.6200 \mathrm{E}-02 \quad 5.5003 \mathrm{E}-03$ delayed neutron spectra by delayed group group 1 group $2 \quad$ group 3 group $4 \quad$ group 5 group 6 $\begin{array}{llllll}0.0000 \mathrm{E}+00 & 0.0000 \mathrm{E}+00 & 8.2553 \mathrm{E}-05 & 1.4878 \mathrm{E}-03 & 3.9495 \mathrm{E}-03 & 8.6683 \mathrm{E}-03\end{array}$ $\begin{array}{lllllll}2.8252 \mathrm{E}-03 & 3.9682 \mathrm{E}-03 & 8.6811 \mathrm{E}-03 & 2.8271 \mathrm{E}-02 & 3.0408 \mathrm{E}-02 & 4.5840 \mathrm{E}-02\end{array}$ $\begin{array}{llllll}1.4007 \mathrm{E}-01 & 1.7353 \mathrm{E}-01 & 6.8296 \mathrm{E}-02 & 1.3237 \mathrm{E}-01 & 1.0051 \mathrm{E}-01 & 1.1231 \mathrm{E}-01\end{array}$ 7.5545E-01 7.6591E-01 $8.1440 \mathrm{E}-01 \quad 7.5155 \mathrm{E}-01 \quad 7.6686 \mathrm{E}-01 \quad 7.2141 \mathrm{E}-01$ $1.0085 \mathrm{E}-01 \quad 5.5306 \mathrm{E}-02 \quad 1.0588 \mathrm{E}-01 \quad 8.4685 \mathrm{E}-02 \quad 9.7090 \mathrm{E}-02 \quad 1.1035 \mathrm{E}-01$ $7.8975 \mathrm{E}-04 \quad 1.2388 \mathrm{E}-03 \quad 2.5711 \mathrm{E}-03 \quad 1.5881 \mathrm{E}-03 \quad 1.1554 \mathrm{E}-03 \quad 1.3886 \mathrm{E}-03$ $1.043 \mathrm{E}-05$ 3. $1193 \mathrm{E}-05 \quad 6.1780 \mathrm{E}-053.5635 \mathrm{E}-05 \quad 1.9822 \mathrm{E}-05 \quad 1.629 \mathrm{E}-05$ 1.0043E-05 3.1.93E-05 $6.1780 \mathrm{E}-052.5635 \mathrm{E}-051.9822 \mathrm{E}-05 \mathrm{5} 1.6294 \mathrm{E}-05$ . $1.454 \mathrm{E}-073.059 \mathrm{E}-06 \mathrm{6} .0482 \mathrm{E}-06-3.4780 \mathrm{E}-06 \mathrm{C} 1.9069 \mathrm{E}-06 \mathrm{C} 1.5229 \mathrm{E}-06$

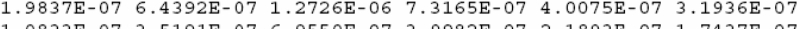

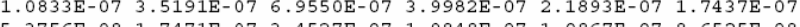
$5.3756 \mathrm{E}-08$ 1.7471E-07 $3.4527 \mathrm{E}-07 \quad 1.9848 \mathrm{E}-07 \quad 1.0867 \mathrm{E}-07 \quad 8.6525 \mathrm{E}-08$

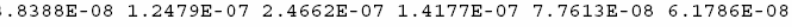

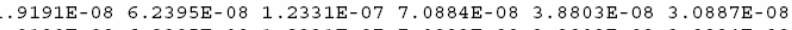
$1.9190 \mathrm{E}-08 \quad 6.2395 \mathrm{E}-08 \quad 1.2331 \mathrm{E}-07 \quad 7.0883 \mathrm{E}-08 \quad 3.8802 \mathrm{E}-08 \quad 3.0884 \mathrm{E}-08$ $\begin{array}{lllllll}1.3047 \mathrm{E}-08 & 4.2429 \mathrm{E}-08 & 8.3848 \mathrm{E}-08 & 4.8198 \mathrm{E}-08 & 2.6383 \mathrm{E}-08 & 2.0999 \mathrm{E}-08\end{array}$ $\begin{array}{llllll}4.9886 \mathrm{E}-09 & 1.6223 \mathrm{E}-08 & 3.2060 \mathrm{E}-08 & 1.8429 \mathrm{E}-08 & 1.0088 \mathrm{E}-08 & 8.0285 \mathrm{E}-09\end{array}$ $\begin{array}{llllll}7.6747 \mathrm{E}-10 & 2.4958 \mathrm{E}-09 & 4.9321 \mathrm{E}-09 & 2.8352 \mathrm{E}-09 & 1.5519 \mathrm{E}-09 & 1.2352 \mathrm{E}-09\end{array}$ $\begin{array}{llllll}1.5349 \mathrm{E}-10 & 4.9916 \mathrm{E}-10 & 9.8644 \mathrm{E}-10 & 5.6704 \mathrm{E}-10 & 3.1038 \mathrm{E}-10 & 2.4703 \mathrm{E}-10\end{array}$ $\begin{array}{llllll}2.2871 \mathrm{E}-10 & 7.4374 \mathrm{E}-10 & 1.4698 \mathrm{E}-09 & 8.4489 \mathrm{E}-10 & 4.6247 \mathrm{E}-10 & 3.6808 \mathrm{E}-10\end{array}$ $1.0000 \mathrm{E}+00 \quad 1.0000 \mathrm{E}+00 \quad 1.0000 \mathrm{E}+00 \quad 1.0000 \mathrm{E}+00 \quad 1.0000 \mathrm{E}+00 \quad 1.0000 \mathrm{E}+00$

mean energy (ev) relative yield

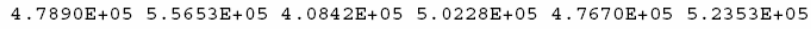
$\begin{array}{llllll}1.8049 \mathrm{E}-02 & 2.2430 \mathrm{E}-01 & 1.4261 \mathrm{E}-01 & 3.4925 \mathrm{E}-01 & 1.9758 \mathrm{E}-01 & 6.8208 \mathrm{E}-02\end{array}$ $\begin{array}{llllll}1.3599 \mathrm{E}-02 & 2.9966 \mathrm{E}-02 & 1.1673 \mathrm{E}-01 & 3.0691 \mathrm{E}-01 & 8.7010 \mathrm{E}-01 & 3.0028 \mathrm{E}+00\end{array}$

Fig. A.1. Selected data from ENDF/B-VI.8 library (continued). 
Delayed Neutron Data for u235 (endf/b-vii.0)

$\begin{array}{rll}\text { broad } & \text { group } \\ \text { grp } & \text { emin }(\mathrm{eV}) & \text { emax }(\mathrm{eV}) \\ 1 & 2.4790 \mathrm{E}+06 & 2.00000 \mathrm{E}+07 \\ 2 & 1.5000 \mathrm{E}+06 & 2.4790 \mathrm{E}+06 \\ 3 & 8.7500 \mathrm{E}+05 & 1.5000 \mathrm{E}+06 \\ 4 & 8.5000 \mathrm{E}+04 & 8.7500 \mathrm{E}+05 \\ 5 & 2.5800 \mathrm{E}+03 & 8.5000 \mathrm{E}+04 \\ 6 & 9.0000 \mathrm{E}+01 & 2.5800 \mathrm{E}+03 \\ 7 & 2.7500 \mathrm{E}+01 & 9.0000 \mathrm{E}+01 \\ 8 & 9.1000 \mathrm{E}+00 & 2.7500 \mathrm{E}+01 \\ 9 & 2.9700 \mathrm{E}+00 & 9.1000 \mathrm{E}+00 \\ 10 & 1.6800 \mathrm{E}+00 & 2.97000 \mathrm{E}+00 \\ 11 & 9.7500 \mathrm{E}-01 & 1.6800 \mathrm{E}+00 \\ 12 & 6.2500 \mathrm{E}-01 & 9.7500 \mathrm{E}-01 \\ 13 & 3.7500 \mathrm{E}-01 & 6.2500 \mathrm{E}-01 \\ 14 & 2.5000 \mathrm{E}-01 & 3.7500 \mathrm{E}-01 \\ 15 & 1.2500 \mathrm{E}-01 & 2.5000 \mathrm{E}-01 \\ 16 & 4.0000 \mathrm{E}-02 & 1.2500 \mathrm{E}-01 \\ 17 & 7.5000 \mathrm{E}-03 & 4.0000 \mathrm{E}-02 \\ 18 & 2.5000 \mathrm{E}-03 & 7.5000 \mathrm{E}-03 \\ 19 & 1.5000 \mathrm{E}-03 & 2.5000 \mathrm{E}-03 \\ 20 & 1.0000 \mathrm{E}-05 & 1.5000 \mathrm{E}-03\end{array}$

total

nubar beta

$3.9991 \mathrm{E}+00 \quad 9.0000 \mathrm{E}-03 \quad 2.2505 \mathrm{E}-03$ $2.6522 \mathrm{E}+00 \quad 1.6700 \mathrm{E}-02 \quad 6.2967 \mathrm{E}-03$ $2.5554 \mathrm{E}+00 \quad 1.6700 \mathrm{E}-02 \quad 6.5351 \mathrm{E}-0$ $2.4236 \mathrm{E}+00 \quad 1.6594 \mathrm{E}-02 \quad 6.8470 \mathrm{E}-03$ $2.4338 \mathrm{E}+00 \quad 1.5873 \mathrm{E}-02 \quad 6.5218 \mathrm{E}-03$ $2.4351 \mathrm{E}+00 \quad 1.5851 \mathrm{E}-02 \quad 6.5093 \mathrm{E}-03$ $2.4364 \mathrm{E}+00 \quad 1.5850 \mathrm{E}-02 \quad 6.5055 \mathrm{E}-03$ $2.4367 \mathrm{E}+00 \quad 1.5850 \mathrm{E}-02 \quad 6.5047 \mathrm{E}-03$ $2.4367 \mathrm{E}+00 \quad 1.5850 \mathrm{E}-02 \quad 6.5047 \mathrm{E}-03$ $2.4367 \mathrm{E}+00 \quad 1.5850 \mathrm{E}-02 \quad 6.5047 \mathrm{E}-03$ $2.4367 \mathrm{E}+00 \quad 1.5850 \mathrm{E}-02 \quad 6.5047 \mathrm{E}-03$ $2.4367 \mathrm{E}+00 \quad 1.5850 \mathrm{E}-02 \quad 6.5047 \mathrm{E}-03$ $2.4367 \mathrm{E}+00 \quad 1.5850 \mathrm{E}-02 \quad 6.5047 \mathrm{E}-03$ $2.4367 \mathrm{E}+00 \quad 1.5850 \mathrm{E}-02 \quad 6.5047 \mathrm{E}-03$ $2.4367 \mathrm{E}+00 \quad 1.5850 \mathrm{E}-02 \quad 6.5047 \mathrm{E}-03$ $2.4367 \mathrm{E}+00$ 1.5850E-02 $6.5047 \mathrm{E}-03$ $2.4367 \mathrm{E}+001.5850 \mathrm{E}-026.5047 \mathrm{E}-03$ $2.4367 \mathrm{E}+001.5850 \mathrm{E}-026.5047 \mathrm{E}-03$ $\begin{array}{lll}2.4367 \mathrm{E}+00 & 1.5850 \mathrm{E}-02 & 6.5047 \mathrm{E}-03 \\ 2.4367 \mathrm{E}+00 & 1.5850 \mathrm{E}-02 & 6.5047 \mathrm{E}-03\end{array}$

mean energy (ev) relative yield
decay constant

delayed neutron spectra by delayed group group 1 group 2 group 3 group 4 group 5 group 6

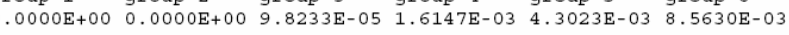

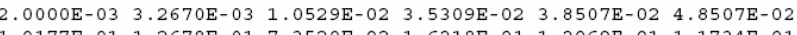
$1.0177 \mathrm{E}-011.2678 \mathrm{E}-017.3520 \mathrm{E}-021.6218 \mathrm{E}-01$ 1.2069E- 01 1.1734E-01 7.5025E-01 7.70 $\begin{array}{llllll}1.4474 \mathrm{E}-01 & 9.6349 \mathrm{E}-02 & 9.1538 \mathrm{E}-02 & 7.3115 \mathrm{E}-02 & 9.0706 \mathrm{E}-02 & 1.0778 \mathrm{E}-01\end{array}$ $\begin{array}{llllll}1.2158 \mathrm{E}-03 & 2.6405 \mathrm{E}-03 & 1.9572 \mathrm{E}-03 & 1.3199 \mathrm{E}-03 & 1.1886 \mathrm{E}-03 & 1.4621 \mathrm{E}-03\end{array}$ $\begin{array}{llllll}1.5486 \mathrm{E}-05 & 6.6078 \mathrm{E}-05 & 4.6314 \mathrm{E}-05 & 2.9550 \mathrm{E}-05 & 2.0073 \mathrm{E}-05 & 1.5841 \mathrm{E}-05\end{array}$ $\begin{array}{llllll}4.4189 \mathrm{E}-06 & 1.9452 \mathrm{E}-05 & 1.3609 \mathrm{E}-05 & 8.6662 \mathrm{E}-06 & 5.8185 \mathrm{E}-06 & 4.4689 \mathrm{E}-06\end{array}$ 1.4580E-06 6.4801E-06 $4.5311 \mathrm{E}-06 \quad 2.8838 \mathrm{E}-06 \quad 1.9292 \mathrm{E}-06 \quad 1.4692 \mathrm{E}-06$ $\begin{array}{llllll}3.0592 \mathrm{E}-07 & 1.3636 \mathrm{E}-06 & 9.5335 \mathrm{E}-07 & 6.0664 \mathrm{E}-07 & 4.0541 \mathrm{E}-07 & 3.0792 \mathrm{E}-07\end{array}$ $\begin{array}{llllll}1.6706 \mathrm{E}-07 & 7.4525 \mathrm{E}-07 & 5.2099 \mathrm{E}-07 & 3.3151 \mathrm{E}-07 & 2.2147 \mathrm{E}-07 & 1.6810 \mathrm{E}-07\end{array}$ $\begin{array}{lllllll}8.2900 \mathrm{E}-08 & 3.6999 \mathrm{E}-07 & 2.5864 \mathrm{E}-07 & 1.6457 \mathrm{E}-07 & 1.0993 \mathrm{E}-07 & 8.3406 \mathrm{E}-08\end{array}$ $\begin{array}{llllll}5.9201 \mathrm{E}-08 & 2.6427 \mathrm{E}-07 & 1.8474 \mathrm{E}-07 & 1.1755 \mathrm{E}-07 & 7.8512 \mathrm{E}-08 & 5.9555 \mathrm{E}-08\end{array}$ $\begin{array}{llllll}2.9597 \mathrm{E}-08 & 1.3213 \mathrm{E}-07 & 9.2370 \mathrm{E}-08 & 5.8773 \mathrm{E}-08 & 3.9252 \mathrm{E}-08 & 2.9771 \mathrm{E}-08\end{array}$ $\begin{array}{llllll}2.9593 \mathrm{E}-08 & 1.3213 \mathrm{E}-07 & 9.2370 \mathrm{E}-08 & 5.8771 \mathrm{E}-08 & 3.9250 \mathrm{E}-08 & 2.9767 \mathrm{E}-08\end{array}$ $2.0122 \mathrm{E}-08 \quad 8.9854 \mathrm{E}-08 \quad 6.2812 \mathrm{E}-08 \quad 3.9964 \mathrm{E}-08 \quad 2.6689 \mathrm{E}-08 \quad 2.0240 \mathrm{E}-08$ 7.6933E-09 $3.4355 \mathrm{E}-082.4016 \mathrm{E}-08$ 1.5280 08 . $1.0205 \mathrm{E}-087.7380 \mathrm{E}-09$

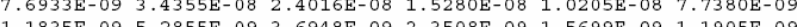
$\begin{array}{llllll}1.1835 \mathrm{E}-09 & 5.2855 \mathrm{E}-09 & 3.6948 \mathrm{E}-09 & 2.3508 \mathrm{E}-09 & 1.5699 \mathrm{E}-09 & 1.1905 \mathrm{E}-09\end{array}$

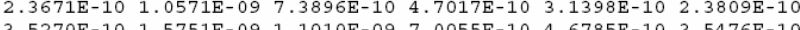
$1.0000 \mathrm{E}+00 \quad 1.0000 \mathrm{E}+00 \quad 1.0000 \mathrm{E}+00 \quad 1.0000 \mathrm{E}+00 \quad 1.0000 \mathrm{E}+00 \quad 1.0000 \mathrm{E}+00$

$\begin{array}{llllll}4.0079 \mathrm{E}+05 \quad 4.6901 \mathrm{E}+05 \quad 4.3925 \mathrm{E}+05 & 5.5373 \mathrm{E}+05 & 5.1401 \mathrm{E}+05 & 5.3587 \mathrm{E}+05\end{array}$ 3.1973E-02 1.6637E-01 1.6131E-01 4.5965E-01 $1.3350 \mathrm{E}-01 \quad 4.7200 \mathrm{E}-02$

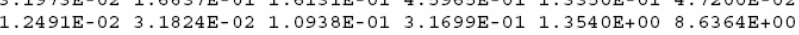

Delayed Neutron Data for u238 (endf/b-vii.0)

$\begin{array}{rll}\text { broad } & \text { group } \\ \text { grp } & \text { emin(eV) } & \text { emax (eV) } \\ 1 & 2.4790 \mathrm{E}+06 & 2.0000 \mathrm{E}+07 \\ 2 & 1.5000 \mathrm{E}+06 & 2.4790 \mathrm{E}+06 \\ 3 & 8.7500 \mathrm{E}+05 & 1.5000 \mathrm{E}+06 \\ 4 & 8.5000 \mathrm{E}+04 & 8.7500 \mathrm{E}+05 \\ 5 & 2.5800 \mathrm{E}+03 & 8.5000 \mathrm{E}+04 \\ 6 & 9.0000 \mathrm{E}+01 & 2.5800 \mathrm{E}+03 \\ 7 & 2.7500 \mathrm{E}+01 & 9.0000 \mathrm{E}+01 \\ 8 & 9.1000 \mathrm{E}+00 & 2.7500 \mathrm{E}+01 \\ 9 & 2.9700 \mathrm{E}+00 & 9.1000 \mathrm{E}+00 \\ 10 & 1.6800 \mathrm{E}+00 & 2.9700 \mathrm{E}+00 \\ 11 & 9.7500 \mathrm{E}-01 & 1.6800 \mathrm{E}+00 \\ 12 & 6.2500 \mathrm{E}-01 & 9.7500 \mathrm{E}-01 \\ 13 & 3.7500 \mathrm{E}-01 & 6.2500 \mathrm{E}-01 \\ 14 & 2.5000 \mathrm{E}-01 & 3.7500 \mathrm{E}-01 \\ 15 & 1.2500 \mathrm{E}-01 & 2.5000 \mathrm{E}-01 \\ 16 & 4.0000 \mathrm{E}-02 & 1.2500 \mathrm{E}-01 \\ 17 & 7.5000 \mathrm{E}-03 & 4.0000 \mathrm{E}-02 \\ 18 & 2.5000 \mathrm{E}-03 & 7.5000 \mathrm{E}-03 \\ 19 & 1.5000 \mathrm{E}-03 & 2.5000 \mathrm{E}-03 \\ 20 & 1.0000 \mathrm{E}-05 & 1.5000 \mathrm{E}-03\end{array}$

total delaye

total

$\begin{array}{lll}\text { nubar } & \text { nubar } & \text { beta } \\ 4.0282 \mathrm{E}+00 & 2.6000 \mathrm{E}-02 & 6.4544 \mathrm{E}-03\end{array}$ $2.6339 \mathrm{E}+00 \quad 4.4000 \mathrm{E}-02 \quad 1.6705 \mathrm{E}-02$ $2.5767 \mathrm{E}+00 \quad 4.4000 \mathrm{E}-02 \quad 1.7076 \mathrm{E}-02$ $2.5263 \mathrm{E}+00 \quad 4.4000 \mathrm{E}-02 \quad 1.7417 \mathrm{E}-02$ $2.4952 \mathrm{E}+00 \quad 4.4000 \mathrm{E}-02 \quad 1.7634 \mathrm{E}-02$ $2.4922 \mathrm{E}+00 \quad 4.4000 \mathrm{E}-02 \quad 1.7655 \mathrm{E}-02$ $2.4921 \mathrm{E}+00 \quad 4.4000 \mathrm{E}-02 \quad 1.7656 \mathrm{E}-02$ $2.4921 \mathrm{E}+00 \quad 4.4000 \mathrm{E}-02 \quad 1.7656 \mathrm{E}-02$ $\begin{array}{lll}2.4921 \mathrm{E}+00 & 4.4000 \mathrm{E}-02 & 1.7656 \mathrm{E}-02 \\ 2.4921 \mathrm{E}+00 & 4.4000 \mathrm{E}-02 & 1.7656 \mathrm{E}-02\end{array}$ $\begin{array}{lll}2.4921 \mathrm{E}+00 & 4.4000 \mathrm{E}-02 & 1.7656 \mathrm{E}-02 \\ 2.4921 \mathrm{E}+00 & 4.4000 \mathrm{E}-02 & 1.7656 \mathrm{E}-02\end{array}$ $\begin{array}{lll}2.4921 \mathrm{E}+00 & 4.4000 \mathrm{E}-02 & 1.7656 \mathrm{E}-02 \\ 2.4921 \mathrm{E}+00 & 4.4000 \mathrm{E}-02 & 1.7656 \mathrm{E}-02\end{array}$ $\begin{array}{lll}2.4921 \mathrm{E}+00 & 4.4000 \mathrm{E}-02 & 1.7656 \mathrm{E}-02 \\ 2.4921 \mathrm{E}+00 & 4.4000 \mathrm{E}-02 & 1.7656 \mathrm{E}-02\end{array}$ $\begin{array}{lll}2.4921 \mathrm{E}+00 & 4.4000 \mathrm{E}-02 & 1.7656 \mathrm{E}-02 \\ 2.4921 \mathrm{E}+00 & 4.4000 \mathrm{E}-02 & 1.7656 \mathrm{E}-02\end{array}$ $\begin{array}{lll}2.4921 \mathrm{E}+00 & 4.4000 \mathrm{E}-02 & 1.7656 \mathrm{E}-02 \\ 2.4921 \mathrm{E}+00 & 4.4000 \mathrm{E}-02 & 1.7656 \mathrm{E}-02\end{array}$ $\begin{array}{lll}2.4921 \mathrm{E}+00 & 4.4000 \mathrm{E}-02 & 1.7656 \mathrm{E}-02 \\ 2.4921 \mathrm{E}+00 & 4.4000 \mathrm{E}-02 & 1.7656 \mathrm{E}-02\end{array}$

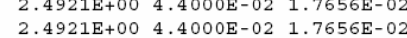
$\begin{array}{lll}2.4921 \mathrm{E}+00 & 4.4000 \mathrm{E}-02 & 1.7656 \mathrm{E}-02 \\ 2.4921 \mathrm{E}+00 & 4.4000 \mathrm{E}-02 & 1.7656 \mathrm{E}-02\end{array}$ $\begin{array}{lll}2.4921 \mathrm{E}+00 & 4.4000 \mathrm{E}-02 & 1.7656 \mathrm{E}-02 \\ 2.4921 \mathrm{E}+00 & 4.4000 \mathrm{E}-02 & 1.7656 \mathrm{E}-02\end{array}$ $\begin{array}{lll}2.4921 \mathrm{E}+00 & 4.4000 \mathrm{E}-02 & 1.7656 \mathrm{E}-02 \\ 2.4921 \mathrm{E}+00 & 4.4000 \mathrm{E}-02 & 1.7656 \mathrm{E}-02\end{array}$ $2.4921 \mathrm{E}+00 \quad 4.4000 \mathrm{E}-02 \quad 1.7656 \mathrm{E}-02$

mean energy (ev) relative yield decay constant

Delayed Neutron Data for pu239 (endf/b-vii.0)

$\begin{array}{rll}\text { broad } & \text { group } \\ \text { grp } & \text { emin }(\mathrm{eV}) & \text { emax }(\mathrm{eV}) \\ 1 & 2.4790 \mathrm{E}+06 & 2.0000 \mathrm{E}+07 \\ 2 & 1.5000 \mathrm{E}+06 & 2.4790 \mathrm{E}+06 \\ 3 & 8.7500 \mathrm{E}+05 & 1.5000 \mathrm{E}+06 \\ 4 & 8.5000 \mathrm{E}+04 & 8.7500 \mathrm{E}+05 \\ 5 & 2.5800 \mathrm{E}+03 & 8.5000 \mathrm{E}+04 \\ 6 & 9.0000 \mathrm{E}+01 & 2.5800 \mathrm{E}+03 \\ 7 & 2.7500 \mathrm{E}+01 & 9.0000 \mathrm{E}+01 \\ 8 & 9.1000 \mathrm{E}+00 & 2.7500 \mathrm{E}+01 \\ 9 & 2.9700 \mathrm{E}+00 & 9.1000 \mathrm{E}+00 \\ 10 & 1.6800 \mathrm{E}+00 & 2.9700 \mathrm{E}+00 \\ 11 & 9.7500 \mathrm{E}-01 & 1.6800 \mathrm{E}+00 \\ 12 & 6.2500 \mathrm{E}-01 & 9.7500 \mathrm{E}-01 \\ 13 & 3.7500 \mathrm{E}-01 & 6.2500 \mathrm{E}-01 \\ 14 & 2.5000 \mathrm{E}-01 & 3.7500 \mathrm{E}-01 \\ 15 & 1.2500 \mathrm{E}-01 & 2.5000 \mathrm{E}-01 \\ 16 & 4.0000 \mathrm{E}-02 & 1.2500 \mathrm{E}-01 \\ 17 & 7.5000 \mathrm{E}-03 & 4.0000 \mathrm{E}-02 \\ 18 & 2.5000 \mathrm{E}-03 & 7.5000 \mathrm{E}-03 \\ 19 & 1.5000 \mathrm{E}-03 & 2.5000 \mathrm{E}-03 \\ 20 & 1.0000 \mathrm{E}-05 & 1.5000 \mathrm{E}-03\end{array}$

total delayed total $\begin{array}{lll}\text { nubar } & \text { nubar } & \text { beta } \\ 4.5568 \mathrm{E}+00 & 4.3000 \mathrm{E}-03 & 9.4365 \mathrm{E}-04\end{array}$ $3.1764 \mathrm{E}+00 \quad 6.4500 \mathrm{E}-03 \quad 2.0306 \mathrm{E}-03$ $3.0440 \mathrm{E}+00 \quad 6.4500 \mathrm{E}-03 \quad 2.1189 \mathrm{E}-03$ $2.9430 \mathrm{E}+00 \quad 6.4500 \mathrm{E}-03 \quad 2.1916 \mathrm{E}-03$ $2.8956 \mathrm{E}+00 \quad 6.4500 \mathrm{E}-03 \quad 2.2275 \mathrm{E}-03$ $2.8943 \mathrm{E}+00 \quad 6.4500 \mathrm{E}-03 \quad 2.2285 \mathrm{E}-03$ $2.8872 \mathrm{E}+00 \quad 6.4500 \mathrm{E}-03 \quad 2.2340 \mathrm{E}-03$

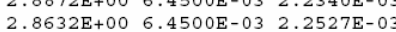
$\begin{array}{lll}2.8632 \mathrm{E}+00 & 6.4500 \mathrm{E}-03 & 2.2527 \mathrm{E}-03 \\ 2.8704 \mathrm{E}+00 & 6.4500 \mathrm{E}-03 & 2.2471 \mathrm{E}-03\end{array}$ $\begin{array}{lll}2.8704 \mathrm{E}+00 & 6.4500 \mathrm{E}-03 & 2.2471 \mathrm{E}-03 \\ 2.8788 \mathrm{E}+00 & 6.4500 \mathrm{E}-03 & 2.2405 \mathrm{E}-03\end{array}$ $\begin{array}{lll}2.8788 \mathrm{E}+00 & 6.4500 \mathrm{E}-03 & 2.2405 \mathrm{E}-03 \\ 2.8787 \mathrm{E}+00 & 6.4500 \mathrm{E}-03 & 2.2406 \mathrm{E}-03\end{array}$ $\begin{array}{lll}2.8787 \mathrm{E}+00 & 6.4500 \mathrm{E}-03 & 2.2406 \mathrm{E}-03 \\ 2.8746 \mathrm{E}+00 & 6.4500 \mathrm{E}-03 & 2.2438 \mathrm{E}-03 \\ 2.8654 \mathrm{E}+00 & 6.4500 \mathrm{E}-03 & 2.2510 \mathrm{E}-03\end{array}$ $\begin{array}{lll}2.8746 \mathrm{E}+00 & 6.4500 \mathrm{E}-03 & 2.2438 \mathrm{E}-03 \\ 2.8654 \mathrm{E}+00 & 6.4500 \mathrm{E}-03 & 2.2510 \mathrm{E}-03\end{array}$ $\begin{array}{lll}2.8654 \mathrm{E}+00 & 6.4500 \mathrm{E}-03 & 2.2510 \mathrm{E}-03 \\ 2.8578 \mathrm{E}+00 & 6.4500 \mathrm{E}-03 & 2.2570 \mathrm{E}-03\end{array}$ $\begin{array}{lll}2.8578 \mathrm{E}+00 & 6.4500 \mathrm{E}-03 & 2.2570 \mathrm{E}-03 \\ 2.8631 \mathrm{E}+00 & 6.4500 \mathrm{E}-03 & 2.2528 \mathrm{E}-03\end{array}$ $\begin{array}{lll}2.8631 \mathrm{E}+00 & 6.4500 \mathrm{E}-03 & 2.2528 \mathrm{E}-03 \\ 2.8739 \mathrm{E}+00 & 6.4500 \mathrm{E}-03 & 2.2443 \mathrm{E}-03\end{array}$ $\begin{array}{lll}2.8739 \mathrm{E}+00 & 6.4500 \mathrm{E}-03 & 2.2443 \mathrm{E}-03 \\ 2.8790 \mathrm{E}+00 & 6.4500 \mathrm{E}-03 & 2.2404 \mathrm{E}-03\end{array}$ $\begin{array}{lll}2.8790 \mathrm{E}+00 & 6.4500 \mathrm{E}-03 & 2.2404 \mathrm{E}-03 \\ 2.83 & \end{array}$ $\begin{array}{lll}2.8804 \mathrm{E}+00 & 6.4500 \mathrm{E}-03 & 2.2393 \mathrm{E}-03 \\ 2.8806 \mathrm{E}+00 & 6.4500 \mathrm{E}-03 & 2.2391 \mathrm{E}-03\end{array}$ $\begin{array}{lll}2.8806 \mathrm{E}+00 & 6.4500 \mathrm{E}-03 & 2.2391 \mathrm{E}-03 \\ 2.8807 \mathrm{E} & 0 & 0\end{array}$ $2.8807 \mathrm{E}+00 \quad 6.4500 \mathrm{E}-03 \quad 2.2391 \mathrm{E}-03$

sum

mean energy (ev) decay constant delayed neutron spectra by delayed group

group 1 group 2 group 3 group 4 group 5 group 6

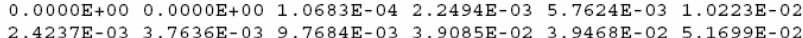
$1.2144 \mathrm{E}-01 \quad 1.4521 \mathrm{E}-01 \quad 7.2600 \mathrm{E}-02 \quad 1.6085 \mathrm{E}-01 \quad 1.1106 \mathrm{E}-01 \quad 1.2190 \mathrm{E}-01$ 7.5290E-01 7.6739E-01 8.1765E-01 7.1788E-01 7.4555E-01 $7.1370 \mathrm{E}-01$

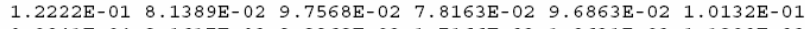
$\begin{array}{llllll}9.9841 \mathrm{E}-04 & 2.1617 \mathrm{E}-03 & 2.2262 \mathrm{E}-03 & 1.7166 \mathrm{E}-03 & 1.2631 \mathrm{E}-03 & 1.1290 \mathrm{E}-03\end{array}$ 1.2707E-05 $5.4550 \mathrm{E}-05 \quad 5.3003 \mathrm{E}-05 \quad 4.0074 \mathrm{E}-05 \quad 2.3760 \mathrm{E}-05 \quad 1.4931 \mathrm{E}-05$

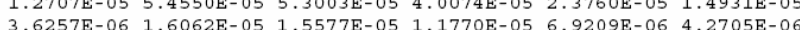
$3.6257 \mathrm{E}-06$ 1.606 $1.605 \mathrm{E}-051.557 \mathrm{E}-05$ 1.1770 -05 6.9209E-06 $4.2705 \mathrm{E}-06$

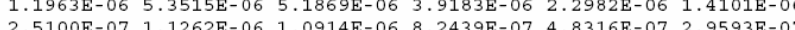
$2.5100 \mathrm{E}-07$
1.3707 1.3707E-07 6.1547E-07 5.964

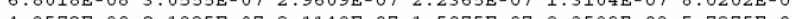

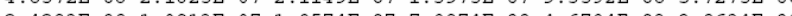
$2.4283 \mathrm{E}-08$ 1.0913E-07 1.0574E-07 7.9874E-08 $4.6794 \mathrm{E}-082.8634 \mathrm{E}-08$

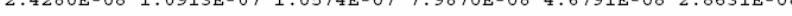

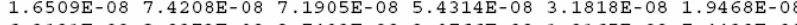
$\begin{array}{llllll}6.3121 \mathrm{E}-09 & 2.8373 \mathrm{E}-08 & 2.7493 \mathrm{E}-08 & 2.0766 \mathrm{E}-08 & 1.2165 \mathrm{E}-08 & 7.4430 \mathrm{E}-09\end{array}$

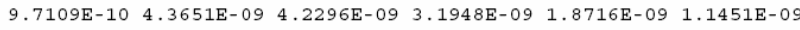

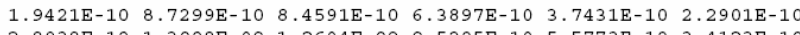
$2.8938 \mathrm{E}-10 \quad 1.3008 \mathrm{E}-09 \quad 1.2604 \mathrm{E}-09 \quad 9.5205 \mathrm{E}-10 \quad 5.5773 \mathrm{E}-10 \quad 3.4123 \mathrm{E}-10$

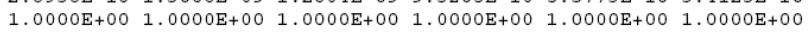

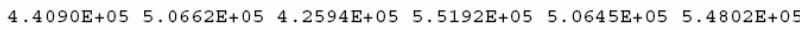
$\begin{array}{llllll}1.0341 \mathrm{E}-02 & 1.1482 \mathrm{E}-01 & 1.2781 \mathrm{E}-01 & 4.5184 \mathrm{E}-01 & 2.3351 \mathrm{E}-01 & 6.1689 \mathrm{E}-02 \\ 1.2494 \mathrm{E}-02 & 3.0255 \mathrm{E}-02 & 1.1594 \mathrm{E}-01 & 3.4148 \mathrm{E}-01 & 1.3186 \mathrm{E}+00 & 9.9790 \mathrm{E}+00\end{array}$

delayed neutron spectra by delayed group

group 1 group 2 group 3 group 4 group 5 group 6 $0.0000 \mathrm{E}+00 \quad 0.0000 \mathrm{E}+00 \quad 7.0488 \mathrm{E}-05 \quad 1.1506 \mathrm{E}-03 \quad 2.8300 \mathrm{E}-03 \quad 8.3058 \mathrm{E}-03$ $\begin{array}{llllll}2.0952 \mathrm{E}-03 & 3.6845 \mathrm{E}-03 & 8.8427 \mathrm{E}-03 & 2.5493 \mathrm{E}-02 & 2.5151 \mathrm{E}-02 & 4.4540 \mathrm{E}-02\end{array}$ $\begin{array}{llllll}1.0618 \mathrm{E}-01 & 1.5938 \mathrm{E}-01 & 6.7873 \mathrm{E}-02 & 1.3179 \mathrm{E}-01 & 9.6010 \mathrm{E}-02 & 1.0396 \mathrm{E}-01\end{array}$ 7.5087E-01 7.6787E-01 8.1492E-01 7.5847E-01 7.8572E-01 $7.2605 \mathrm{E}-01$ $\begin{array}{llllll}1.3967 \mathrm{E}-01 & 6.7388 \mathrm{E}-02 & 1.0558 \mathrm{E}-01 & 8.1804 \mathrm{E}-02 & 8.9309 \mathrm{E}-02 & 1.1546 \mathrm{E}-01\end{array}$ $\begin{array}{llllll}1.1647 \mathrm{E}-03 & 1.6259 \mathrm{E}-03 & 2.6257 \mathrm{E}-03 & 1.2614 \mathrm{E}-03 & 9.6021 \mathrm{E}-04 & 1.6605 \mathrm{E}-03\end{array}$ $1.4837 \mathrm{E}-05 \quad 4.0676 \mathrm{E}-056.3258 \mathrm{E}-05 \quad 2.6733 \mathrm{E}-05 \quad 1.5428 \mathrm{E}-05 \quad 1.6836 \mathrm{E}-05$

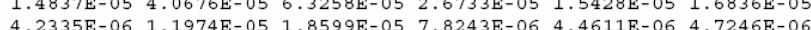

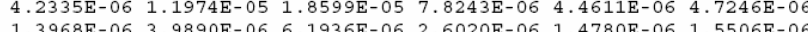
$\begin{array}{llllll}1.3968 \mathrm{E}-06 & 3.9890 \mathrm{E}-06 & 6.1936 \mathrm{E}-06 & 2.6020 \mathrm{E}-06 & 1.4780 \mathrm{E}-06 & 1.5506 \mathrm{E}-06\end{array}$ $\begin{array}{lllllll}2.9309 \mathrm{E}-07 & 8.3944 \mathrm{E}-07 & 1.3032 \mathrm{E}-06 & 5.4727 \mathrm{E}-07 & 3.1052 \mathrm{E}-07 & 3.2482 \mathrm{E}-07\end{array}$ $1.6005 \mathrm{E}-07$ 4.5877E-07 $7.1222 \mathrm{E}-072.9905 \mathrm{E}-07$ 1.6963E-07 $1.7730 \mathrm{E}-07$

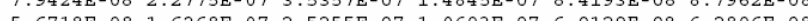
$5.6718 \mathrm{E}-08$ 1.6268E-07 2.5255E-07 $1.0603 \mathrm{E}-076.0129 \mathrm{E}-08 \mathrm{~B} .2806 \mathrm{E}-08$ $2.8354 \mathrm{E}-08 \quad 8.1342 \mathrm{E}-081.2628 \mathrm{E}-07507.3014 \mathrm{E}-08-3.0062 \mathrm{E}-08 \quad 3.1396 \mathrm{E}-08$ $2.8352 \mathrm{E}-08 \quad 8.1342 \mathrm{E}-08 \quad 1.2628 \mathrm{E}-07-5.3014 \mathrm{E}-08$ 3.0060E-08 $3.1391 \mathrm{E}-08$ $\begin{array}{llllll}1.9277 \mathrm{E}-08 & 5.5310 \mathrm{E}-08 & 8.5866 \mathrm{E}-08 & 3.6049 \mathrm{E}-08 & 2.0440 \mathrm{E}-08 & 2.1343 \mathrm{E}-08\end{array}$ $\begin{array}{llllll}7.3704 \mathrm{E}-09 & 2.1149 \mathrm{E}-08 & 3.2831 \mathrm{E}-08 & 1.3783 \mathrm{E}-08 & 7.8151 \mathrm{E}-09 & 8.1600 \mathrm{E}-09\end{array}$ $\begin{array}{llllll}1.1339 \mathrm{E}-09 & 3.2535 \mathrm{E}-09 & 5.0510 \mathrm{E}-09 & 2.1205 \mathrm{E}-09 & 1.2023 \mathrm{E}-09 & 1.2554 \mathrm{E}-09\end{array}$ $\begin{array}{llllll}2.2679 \mathrm{E}-10 & 6.5071 \mathrm{E}-10 & 1.0102 \mathrm{E}-09 & 4.2411 \mathrm{E}-10 & 2.4047 \mathrm{E}-10 & 2.5108 \mathrm{E}-10\end{array}$

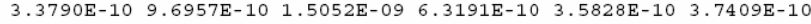
$1.0000 \mathrm{E}+00 \quad 1.0000 \mathrm{E}+00 \quad 1.0000 \mathrm{E}+00 \quad 1.0000 \mathrm{E}+00 \quad 1.0000 \mathrm{E}+00 \quad 1.0000 \mathrm{E}+00$

$\begin{array}{llllll}4.0980 \mathrm{E}+05 & 5.2880 \mathrm{E}+05 & 4.1036 \mathrm{E}+05 & 5.0153 \mathrm{E}+05 & 4.6440 \mathrm{E}+05 & 5.1316 \mathrm{E}+05\end{array}$ $\begin{array}{llllll}3.3084 \mathrm{E}-02 & 2.6807 \mathrm{E}-01 & 1.8711 \mathrm{E}-01 & 3.9075 \mathrm{E}-01 & 1.0395 \mathrm{E}-01 & 1.7041 \mathrm{E}-02\end{array}$ $\begin{array}{llllll}1.2481 \mathrm{E}-02 & 2.9947 \mathrm{E}-02 & 1.0716 \mathrm{E}-01 & 3.1762 \mathrm{E}-01 & 1.3524 \mathrm{E}+00 & 1.0691 \mathrm{E}+01\end{array}$

Fig. A.2. Selected data from ENDF/B-VII.0 library. 
Delayed Neutron Data for puz41 (endf/b-vii.0)

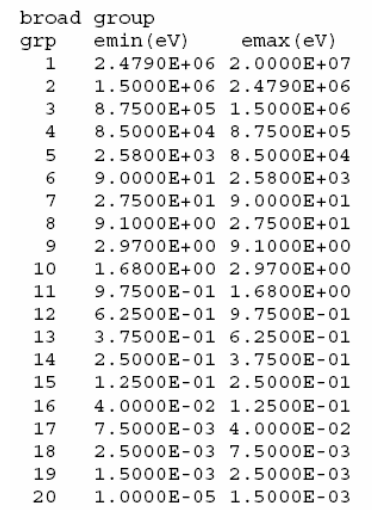

total

nubar

delaye

total

beta

$4.6174 \mathrm{E}+00 \quad 8.4000 \mathrm{E}-03 \quad 1.8192 \mathrm{E}-03$

$3.1867 \mathrm{E}+00 \quad 1.6200 \mathrm{E}-02 \quad 5.0837 \mathrm{E}-03$

$3.0591 \mathrm{E}+00 \quad 1.6200 \mathrm{E}-02 \quad 5.2957 \mathrm{E}-03$

$2.9466 \mathrm{E}+00 \quad 1.6200 \mathrm{E}-02 \quad 5.4979 \mathrm{E}-03$

$2.9453 \mathrm{E}+00 \quad 1.6200 \mathrm{E}-02 \quad 5.5003 \mathrm{E}-03$

$2.9453 \mathrm{E}+001.6200 \mathrm{E}-02 \quad 5.5003 \mathrm{E}-03$

$2.9453 \mathrm{E}+00 \quad 1.6200 \mathrm{E}-02 \quad 5.5003 \mathrm{E}-03$

$2.9453 \mathrm{E}+00 \quad 1.6200 \mathrm{E}-02 \quad 5.5003 \mathrm{E}-03$

$2.9453 \mathrm{E}+00 \quad 1.6200 \mathrm{E}-02 \quad 5.5003 \mathrm{E}-03$

$\begin{array}{lll}2.9453 \mathrm{E}+00 & 1.6200 \mathrm{E}-02 & 5.5003 \mathrm{E}-03 \\ 2.9453 \mathrm{E}+00 & 1.6200 \mathrm{E}-02 & 5.5003 \mathrm{E}-03\end{array}$

$2.9453 \mathrm{E}+00 \quad 1.6200 \mathrm{E}-02 \quad 5.5003 \mathrm{E}-03$

$2.9453 \mathrm{E}+00 \quad 1.6200 \mathrm{E}-02 \quad 5.5003 \mathrm{E}-03$

$2.9453 \mathrm{E}+00 \quad 1.6200 \mathrm{E}-02 \quad 5.5003 \mathrm{E}-0$

$2.9453 \mathrm{E}+00 \quad 1.6200 \mathrm{E}-02 \quad 5.5003 \mathrm{E}-0$

$2.9453 \mathrm{E}+00 \quad 1.6200 \mathrm{E}-02 \quad 5.5003 \mathrm{E}-0$

$2.9453 \mathrm{E}+00 \quad 1.6200 \mathrm{E}-02 \quad 5.5003 \mathrm{E}-0$

$2.9453 \mathrm{E}+00 \quad 1.6200 \mathrm{E}-02 \quad 5.5003 \mathrm{E}-03$

$2.9453 \mathrm{E}+00 \quad 1.6200 \mathrm{E}-02 \quad 5.5003 \mathrm{E}-03$

$2.9453 \mathrm{E}+001.6200 \mathrm{E}-02 \quad 5.5003 \mathrm{E}-03$

$2.9453 \mathrm{E}+00 \quad 1.6200 \mathrm{E}-02 \quad 5.5003 \mathrm{E}-03$

sum

mean energy (eV)

mean energy

decay constant delayed neutron spectra by delayed group

group 1 group 2 group 3 group 4 group 5 group 6

$\begin{array}{llll} & \end{array}$

$\begin{array}{llllll}.8252 \mathrm{E}-03 & 3.9682 \mathrm{E}-03 & 8.6811 \mathrm{E}-03 & 2.8271 \mathrm{E}-02 & 3.0408 \mathrm{E}-02 & 4.5840 \mathrm{E}-02\end{array}$

1.4007E-01 1.7353E-01 6.8296E-02 1.3237E-01 1.0051E-01 1.1231E-01

7.5545E-01 7.6591E-01 8.1440E-01 7.5155E-01 7.6686E-01 7.2141E-01

$\begin{array}{llllll}1.0085 \mathrm{E}-01 & 5.5306 \mathrm{E}-02 & 1.0588 \mathrm{E}-01 & 8.4685 \mathrm{E}-02 & 9.7090 \mathrm{E}-02 & 1.1035 \mathrm{E}-01\end{array}$

$\begin{array}{llllll}7.8975 \mathrm{E}-04 & 1.2388 \mathrm{E}-03 & 2.5711 \mathrm{E}-03 & 1.5881 \mathrm{E}-03 & 1.1554 \mathrm{E}-03 & 1.3886 \mathrm{E}-03\end{array}$

$\begin{array}{lllllll}1.0043 \mathrm{E}-05 & 3.1193 \mathrm{E}-05 & 6.1780 \mathrm{E}-05 & 3.5635 \mathrm{E}-05 & 1.9822 \mathrm{E}-05 & 1.6294 \mathrm{E}-05\end{array}$ $2.8655 \mathrm{E}-06 \quad 9.1841 \mathrm{E}-06 \quad 1.8162 \mathrm{E}-05 \quad 1.0451 \mathrm{E}-05 \quad 5.7499 \mathrm{E}-06 \quad 4.6237 \mathrm{E}-06$

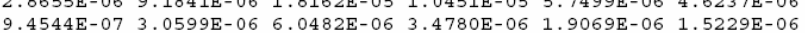
\begin{tabular}{lllllll}
$1.9837 \mathrm{E}-07$ & $6.0599 \mathrm{E}-06$ & $6.0482 \mathrm{E}-06$ & $3.4780 \mathrm{E}-06$ & $1.9069 \mathrm{E}-06$ & $1.5229 \mathrm{E}-06$ \\
\hline
\end{tabular} $\begin{array}{llll} & \end{array}$ $\begin{array}{lllll} & \end{array}$ $\begin{array}{lllllll}3.8388 \mathrm{E}-08 & 1.2479 \mathrm{E}-07 & 2.4662 \mathrm{E}-07 & 1.4177 \mathrm{E}-07 & 7.7613 \mathrm{E}-08 & 6.1786 \mathrm{E}-08\end{array}$ $\begin{array}{llllll}1.9191 \mathrm{E}-08 & 6.2395 \mathrm{E}-08 & 1.2331 \mathrm{E}-07 & 7.0884 \mathrm{E}-08 & 3.8803 \mathrm{E}-08 & 3.0887 \mathrm{E}-08\end{array}$ $\begin{array}{lllllll}1.9190 \mathrm{E}-08 & 6.2395 \mathrm{E}-08 & 1.2331 \mathrm{E}-07 & 7.0883 \mathrm{E}-08 & 3.8802 \mathrm{E}-08 & 3.0884 \mathrm{E}-08\end{array}$ $\begin{array}{lllllll}1.3047 \mathrm{E}-08 & 4.2429 \mathrm{E}-08 & 8.3848 \mathrm{E}-08 & 4.8198 \mathrm{E}-08 & 2.6383 \mathrm{E}-08 & 2.0999 \mathrm{E}-08\end{array}$ $\begin{array}{llllll}4.9886 \mathrm{E}-09 & 1.6223 \mathrm{E}-08 & 3.2060 \mathrm{E}-08 & 1.8429 \mathrm{E}-08 & 1.0088 \mathrm{E}-08 & 8.0285 \mathrm{E}-09\end{array}$ $\begin{array}{llllll}7.6747 \mathrm{E}-10 & 2.4958 \mathrm{E}-09 & 4.9321 \mathrm{E}-09 & 2.8352 \mathrm{E}-09 & 1.5519 \mathrm{E}-09 & 1.2352 \mathrm{E}-09\end{array}$ $\begin{array}{lllllll}1.5349 \mathrm{E}-10 & 4.9916 \mathrm{E}-10 & 9.8644 \mathrm{E}-10 & 5.6704 \mathrm{E}-10 & 3.1038 \mathrm{E}-10 & 2.4703 \mathrm{E}-10\end{array}$ $2.2871 \mathrm{E}-10 \quad 7.4374 \mathrm{E}-10 \quad 1.4698 \mathrm{E}-09 \quad 8.4489 \mathrm{E}-10 \quad 4.6247 \mathrm{E}-10 \quad 3.6808 \mathrm{E}-10$

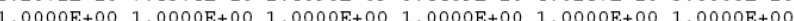

$4.7890 \mathrm{E}+05 \quad 5.5653 \mathrm{E}+05 \quad 4.0842 \mathrm{E}+05 \quad 5.0228 \mathrm{E}+05 \quad 4.7670 \mathrm{E}+05 \quad 5.2353 \mathrm{E}+05$ $\begin{array}{lllllll}1.8049 \mathrm{E}-02 & 2.2430 \mathrm{E}-01 & 1.4261 \mathrm{E}-01 & 3.4925 \mathrm{E}-01 & 1.9758 \mathrm{E}-01 & 6.8208 \mathrm{E}-02\end{array}$ $\begin{array}{llllll}1.3599 \mathrm{E}-02 & 2.9966 \mathrm{E}-02 & 1.1673 \mathrm{E}-01 & 3.0691 \mathrm{E}-01 & 8.7010 \mathrm{E}-01 & 3.0028 \mathrm{E}+00\end{array}$

Fig. A.2. Selected data from ENDF/B-VII.0 library (continued).

Number of Delayed Neutrons Emitted Per ${ }^{235} \mathrm{U}$ Fission

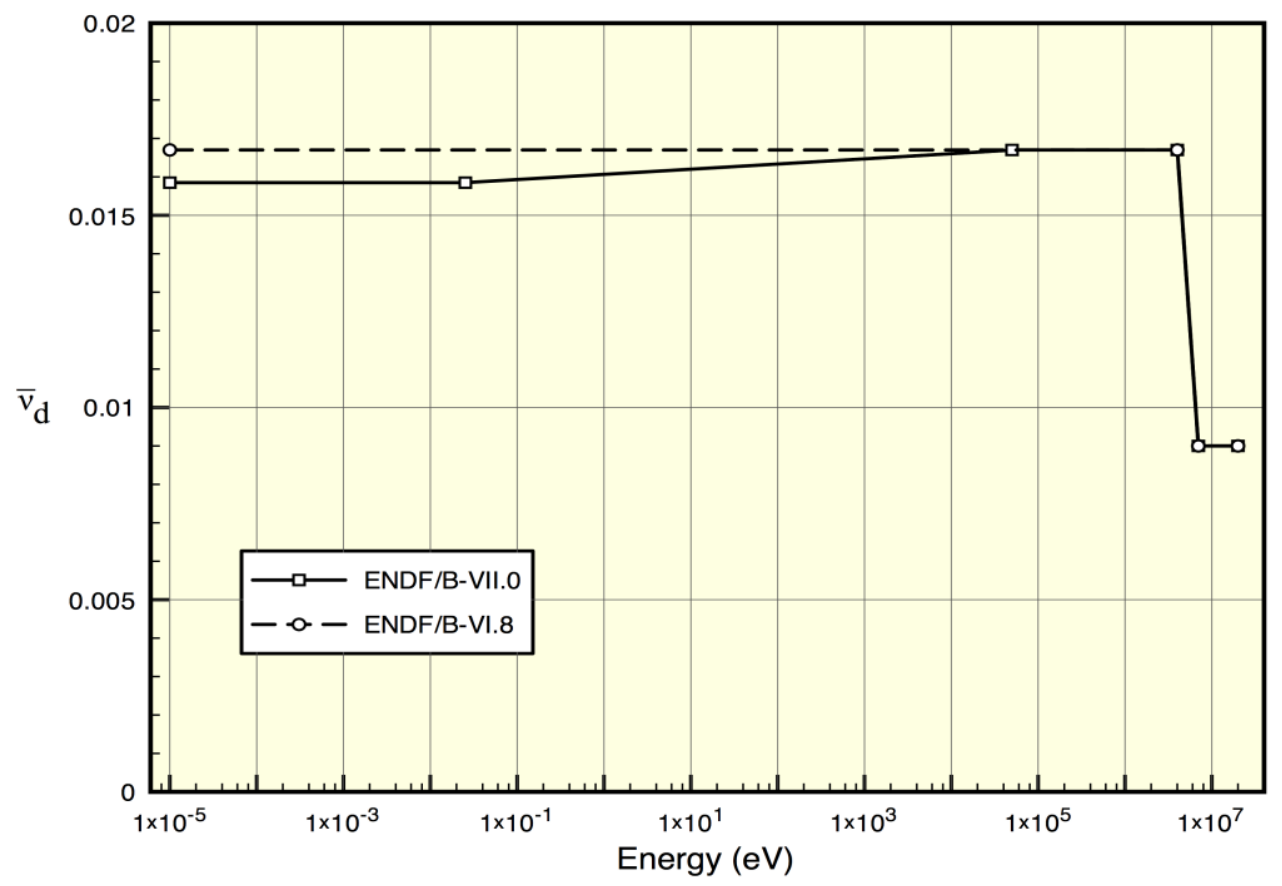

Figure A.3. Comparison of the number of delayed neutrons from 235U fission from ENDF/B-VI.8 and ENDF/B-VII.0 (ENDF/B-VI.8 is identical to ENDF/B-V data). 
Table A.1. Prompt neutron lifetime and effective delayed neutron fractions for the HFIR HEU core (critical conditions throughout the cycle)

\begin{tabular}{|c|c|c|c|c|c|c|c|}
\hline \multirow[b]{2}{*}{$\begin{array}{l}\text { Full Power } \\
\text { Days }\end{array}$} & \multirow[b]{2}{*}{$\begin{array}{c}\text { Prompt Neutron } \\
\text { Lifetime (sec) }\end{array}$} & \multicolumn{3}{|c|}{ ENDF/B-VI.8 } & \multicolumn{3}{|c|}{ ENDF/B-VII.0 } \\
\hline & & Beta & Beta-eff & $\begin{array}{c}\text { Beta-eff/ } \\
\text { Beta }\end{array}$ & Beta & Beta-eff & $\begin{array}{c}\text { Beta-eff/ } \\
\text { Beta }\end{array}$ \\
\hline 0.00 & $5.20 \mathrm{E}-05$ & 6.80E-03 & $7.62 \mathrm{E}-03$ & 1.12 & $6.46 \mathrm{E}-03$ & $7.24 \mathrm{E}-03$ & 1.12 \\
\hline 0.59 & $5.19 E-05$ & $6.80 E-03$ & $7.61 \mathrm{E}-03$ & 1.12 & $6.46 E-03$ & $7.23 E-03$ & 1.12 \\
\hline 1.78 & $6.12 \mathrm{E}-05$ & $6.80 E-03$ & $7.62 \mathrm{E}-03$ & 1.12 & $6.46 \mathrm{E}-03$ & $7.24 \mathrm{E}-03$ & 1.12 \\
\hline 7.18 & $6.76 \mathrm{E}-05$ & 6.79E-03 & $7.60 \mathrm{E}-03$ & 1.12 & $6.45 \mathrm{E}-03$ & $7.22 \mathrm{E}-03$ & 1.12 \\
\hline 14.12 & 7.50E-05 & $6.78 \mathrm{E}-03$ & 7.57E-03 & 1.12 & $6.44 \mathrm{E}-03$ & 7.19E-03 & 1.12 \\
\hline 18.82 & $8.24 \mathrm{E}-05$ & $6.78 \mathrm{E}-03$ & $7.55 E-03$ & 1.11 & $6.44 \mathrm{E}-03$ & 7.17E-03 & 1.11 \\
\hline 21.18 & 8.89E-05 & $6.78 \mathrm{E}-03$ & $7.53 E-03$ & 1.11 & $6.44 \mathrm{E}-03$ & 7.15E-03 & 1.11 \\
\hline 23.53 & $9.02 \mathrm{E}-05$ & $6.78 \mathrm{E}-03$ & $7.53 E-03$ & 1.11 & $6.44 \mathrm{E}-03$ & $7.15 E-03$ & 1.11 \\
\hline 26.00 & $9.43 E-05$ & $6.78 \mathrm{E}-03$ & $7.52 \mathrm{E}-03$ & 1.11 & $6.44 \mathrm{E}-03$ & $7.14 \mathrm{E}-03$ & 1.11 \\
\hline
\end{tabular}

Table A.2. Prompt neutron lifetime and effective delayed neutron fractions for the HFIR LEU (monolithic U-10Mo) core (critical conditions throughout the cycle)

\begin{tabular}{|c|c|c|c|c|c|c|c|}
\hline \multirow[b]{2}{*}{$\begin{array}{l}\text { Full Power } \\
\text { Days }\end{array}$} & \multirow[b]{2}{*}{\begin{tabular}{|} 
Prompt Neutron \\
Lifetime (sec)
\end{tabular}} & \multicolumn{3}{|c|}{ ENDF/B-VI.8 } & \multicolumn{3}{|c|}{ ENDF/B-VII.0 } \\
\hline & & Beta & Beta-eff & $\begin{array}{l}\text { Beta-eff/ } \\
\text { Beta }\end{array}$ & Beta & Beta-eff & $\begin{array}{l}\text { Beta-eff/ } \\
\text { Beta }\end{array}$ \\
\hline 0.00 & $4.68 \mathrm{E}-05$ & 6.90E-03 & $7.49 E-03$ & 1.09 & $6.57 \mathrm{E}-03$ & $7.13 E-03$ & 1.09 \\
\hline 0.59 & 5.02E-05 & 6.90E-03 & $7.46 \mathrm{E}-03$ & 1.08 & 6.57E-03 & 7.11E-03 & 1.08 \\
\hline 1.78 & $5.71 \mathrm{E}-05$ & 6.89E-03 & $7.47 \mathrm{E}-03$ & 1.08 & $6.56 \mathrm{E}-03$ & $7.12 \mathrm{E}-03$ & 1.08 \\
\hline 7.18 & 5.95E-05 & 6.84E-03 & $7.41 \mathrm{E}-03$ & 1.08 & $6.52 \mathrm{E}-03$ & 7.06E-03 & 1.08 \\
\hline 14.12 & $6.44 \mathrm{E}-05$ & $6.77 \mathrm{E}-03$ & $7.31 \mathrm{E}-03$ & 1.08 & $6.45 \mathrm{E}-03$ & $6.97 \mathrm{E}-03$ & 1.08 \\
\hline 18.82 & 7.04E-05 & $6.72 \mathrm{E}-03$ & $7.24 \mathrm{E}-03$ & 1.08 & $6.41 E-03$ & $6.90 \mathrm{E}-03$ & 1.08 \\
\hline 21.18 & 7.11E-05 & 6.70E-03 & $7.22 \mathrm{E}-03$ & 1.08 & $6.39 E-03$ & $6.88 \mathrm{E}-03$ & 1.08 \\
\hline 23.53 & $7.14 \mathrm{E}-05$ & 6.68E-03 & $7.19 \mathrm{E}-03$ & 1.08 & $6.36 \mathrm{E}-03$ & $6.85 E-03$ & 1.08 \\
\hline 26.00 & 7.17E-05 & 6.65E-03 & $7.17 \mathrm{E}-03$ & 1.08 & $6.34 \mathrm{E}-03$ & $6.83 \mathrm{E}-03$ & 1.08 \\
\hline
\end{tabular}

Table A.3. Contributions to effective delayed neutron fraction by nuclide for the HEU and LEU cores computed with ENDF/B-VII.0 data

\begin{tabular}{l|cc|c|c}
\hline \multirow{2}{*}{} & \multicolumn{2}{|c|}{ HEU } & \multicolumn{2}{c}{ LEU } \\
\cline { 2 - 5 } & BOC & EOC & BOC & EOC \\
\hline $\mathrm{U}-235$ & $7.24 \mathrm{E}-03$ & $7.12 \mathrm{E}-03$ & $6.88 \mathrm{E}-03$ & $6.43 \mathrm{E}-03$ \\
$\mathrm{U}-238$ & $2.19 \mathrm{E}-06$ & $2.09 \mathrm{E}-06$ & $2.56 \mathrm{E}-04$ & $2.58 \mathrm{E}-04$ \\
$\mathrm{Pu}-239$ & $3.69 \mathrm{E}-08$ & $1.23 \mathrm{E}-05$ & $3.50 \mathrm{E}-08$ & $1.26 \mathrm{E}-04$ \\
Pu-241 & $3.91 \mathrm{E}-09$ & $5.30 \mathrm{E}-06$ & $3.70 \mathrm{E}-09$ & $1.29 \mathrm{E}-05$ \\
\hline Total & $7.24 \mathrm{E}-03$ & $7.14 \mathrm{E}-03$ & $7.13 \mathrm{E}-03$ & $6.83 \mathrm{E}-03$ \\
\hline
\end{tabular}


ORNL/TM-2007/226

\section{INTERNAL DISTRIBUTION}

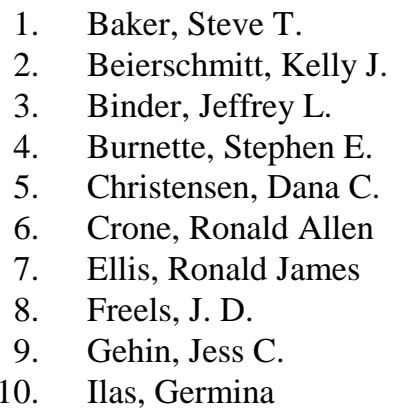

\author{
14. Miller, James Henry \\ 15. Ott, Larry J. \\ 16. Parks, Cecil V. \\ 17. Primm, III, R. T. \\ 18. Rawl, Richard R. \\ 19. Rushton, James E. \\ 20. Satkowiak, Lawrence J. \\ 21. Sease, John D. \\ 22. Smith, Kevin Arthur \\ 23. ORNL Laboratory Records (D. R. Hamrin)
}

\section{EXTERNAL DISTRIBUTION}

24. A. Adams, U.S. Nuclear Regulatory Commission, One White Flint North, 11555 Rockville Pike, Rockville, Maryland 20852-2738 (axa@nrc.gov)

25. T. Andes, BWXT/Y-12, Y-12 National Security Complex, P.O. Box 2009, Oak Ridge, TN 37831-8245 (andestc@y12.doe.gov)

26. R. A. Butler, Director, Research Reactor Center, 1513 Research Park Drive, Columbia, MO 65211 (ButlerRa@missouri.edu)

27. G. S. Chang, Idaho National Laboratory, P.O. Box 1625, Idaho Falls, ID 83415-3885 (gray.chang@inl.gov)

28. D. Diamond, Brookhaven National Laboratory, P.O. Box 5000, Upton, NY 11973-5000 (diamond@bnl.gov)

29. C. Galvez, 637 NW 14th Street, Corvallis, OR 97330 (galvezc@ @erkeley.edu)

30. H. D. Gougar, Manager, Fission \& Fusion Systems, INEEL, P.O. Box 1625, MS 3860, Idaho Falls, ID 83415-3860 (goughd@inl.gov)

31. Klaffky, Roger, Office of Science, U. S. Department of Energy, (roger.klaffky@science.doe.gov)

32. D. Kutikkad, Assistant Reactor Manager-Physics, University of Missouri Research Reactor Facility, Columbia, MO 65211 (kutikkadk@missouri.edu)

33. J. Matos, Argonne National Laboratory, 9700 S. Cass Avenue, Argonne, IL 60439 (jim.matos@anl.gov)

34. C. McKibben, University of Missouri Research Reactor Facility, Columbia, MO 65211 (mckibben@missouri.edu)

35. D. M. Meyer, Idaho National Laboratory, P.O. Box 1625, Idaho Falls, ID 83415-3750 (Dana.Meyer@inl.gov)

36. T. Newton, MIT Nuclear Reactor Laboratory, 138 Albany St., Cambridge, MA 02139 (tnewton@mit.edu)

37. A. P. Olson, Argonne National Laboratory, 9700 S. Cass Avenue, Argonne, IL 60439 (apolson@anl.gov)

38. W. Richards, NIST Center for Neutron Research, 100 Bureau Drive, Stop 8561, Gaithersburg, MD 208998561 (wade.richards@nist.gov)

39. W. C. Richardson, BWXT Technology, Inc., 2016 Mount Athos Rd., Lynchburg, VA 24504 (WCRichardson@bwxt.com)

40. J. Roglans, Argonne National Laboratory, 9700 S. Cass Avenue, Argonne, IL 60439 (roglans@anl.gov)

41. Paul Roth, ATR, Idaho National Laboratory, Idaho Falls, ID 83415 (paul.roth@inl.gov)

42. J. Snelgrove, Argonne National Laboratory, 9700 S. Cass Avenue, Argonne, IL 60439 (jimsnelgrove@anl.gov)

43. P. Staples, NA-212, U.S. Department of Energy, 1000 Independence Avenue SW, Washington, DC 20585 (Parrish.Staples@nnsa.doe.gov)

44. John G. Stevens, Argonne National Laboratory, 9700 S. Cass Avenue, Argonne, IL 60439 (johnstevens@anl.gov) 
45. Daniel M. Wachs, MFC 791 B-147, Idaho National Laboratory, P.O. Box 6188, Idaho Falls, ID 83415 (Daniel.Wachs@inl.gov)

46. R. E. Williams, NIST Center for Neutron Research, 100 Bureau Drive, Stop 8560, Gaithersburg, MD 20899-8560 (robert.williams@nist.gov) 